\title{
Avaliação da prevalência de desqaste dentário em pacientes portadores de transtornos alimentares
}

U] $\mathrm{Nm}$ Jufiana Jufianelli de Araújo

Dissertação apresentada à Faculdade de Odontologia de Bauru da Universidade de São Paulo, como parte dos requisitos para obtenção do título de Mestre em Odontologia, área de concentração Saúde Coletiva. 


\section{Avaliação da prevalência de desgaste dentário em pacientes portadores de transtornos alimentares}

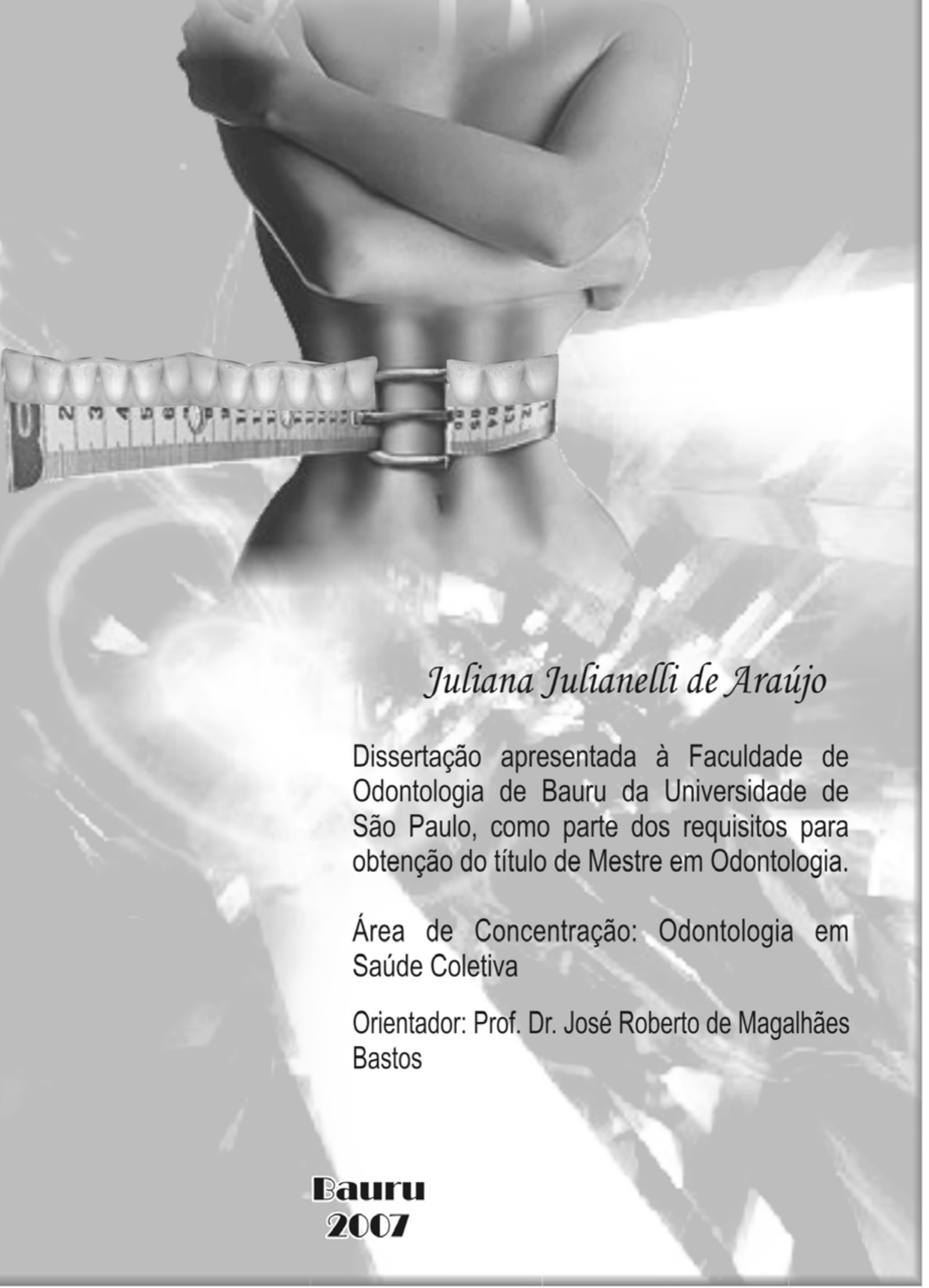




\begin{tabular}{|c|c|}
\hline Ar15a & $\begin{array}{l}\text { Araújo, Juliana Julianelli de } \\
\text { Avaliação da prevalência de desgaste dentário } \\
\text { em pacientes portadores de transtornos alimentares/ } \\
\text { Juliana Julianelli de Araújo - Bauru, } 2007 \text {. } \\
205 \text { p. : il. ; } 30 \mathrm{~cm} \text {. }\end{array}$ \\
\hline de Baurt & $\begin{array}{l}\text { Dissertação (Mestrado) - Faculdade de Odontologia } \\
\text { Universidade de São Paulo }\end{array}$ \\
\hline Bastos & Orientador: Prof. Dr. José Roberto de Magalhães \\
\hline
\end{tabular}

Autorizo, exclusivamente para fins acadêmicos e científicos, a reprodução total ou parcial desta dissertação, por processos fotocopiadores elou meios eletrônicos.

Assinatura do autor:

Data: 1

Comitê de Ética em Pesquisa do Hospital das Clínicas e Faculdade de Medicina de Ribeirão Preto

$N^{\circ}$ de Protocolo: 2832/2007

Data: 25/06/2007 



\section{DADOS CURRICULARES \\ Juliana Julianelli de Araújo}

Nascimento $\quad 13$ de janeiro de 1979

Naturalidade Bauru - SP

Filiação Nelson Correia de Araújo

Elizabeth Julianelli

1997-2001 Curso de Graduação em Odontologia pela Universidade do Sagrado Coração - USC - Bauru - São Paulo

2001-2003 Curso de Especialização em Odontologia em Saúde Coletiva pelo Hospital de Reabilitação em Anomalias Craniofaciais da Universidade de São Paulo

2004-2005 Curso de aperfeiçoamento em Saúde Coletiva pela Faculdade de Odontologia de Bauru da Universidade de São Paulo

2005-2007 Curso de pós-graduação ao nível de mestrado em Odontologia em Saúde Coletiva - Faculdade de Odontologia de Bauru da Universidade de São Paulo

Associações ABENO - Associação Brasileira de Ensino APCD - Associação Paulista de Cirurgiões Dentistas - Regional Bauru, SP

CROSP - Conselho Regional de Odontologia do Estado de São Paulo

SBPqO - Sociedade Brasileira de Pesquisa Odontológica 

“Bom mesmo é ir a luta com determinação, abraçar a vida e viver com paixão, perder com classe e vencer com ousadia, pois o triunfo pertence a quem se atreve... e a vida é muito para ser insignificante" 



\section{"As dificuldades não foram poucas... \\ Os desafios foram muitos...}

Os obstáculos, muitas vezes, pareciam intransponíveis.

Muitas vezes nos sentimos só, e, assim, o estivemos...

$O$ desânimo quis contagiar, porém, a garra e a tenacidade foram mais fortes, sobrepondo esse sentimento, fazendo-nos seguir a caminhada, apesar da sinuosidade do caminho.

Agora, ao olharmos para trás, a sensação do dever cumprido se faz presente e podemos constatar que as noites de sono perdidas, as viagens e visitas realizadas; o cansaço dos encontros, os longos tempos de leitura, digitação, discussão; a ansiedade em querer fazer e a angústia de muitas vezes não o conseguir, por problemas estruturais; não foram em vão.

Aqui estamos, como sobreviventes de uma longa 6atalha, porém, muito mais fortes e hábeis, com coragem suficiente para mudar a nossa postura, apesar de todos os percalços".

(autor desconhecido) 



\title{
DEDICATÓRIA
}

\author{
A minha amada mamãe, \\ Elizabeth Julianelli
}

A quem agradeço a vida, e a quem eu dedico minha vida!

Obrigada por estar do meu lado quando eu preciso. De me criticar quando estou errada. De me abraçar quando me sinto fraca e vulnerável. Obrigada por conversar quando preciso desabafar. $\mathcal{E}$ de me abrir os ofhos quando eles se fecham para tudo e para todos.

Obrigada por falar sempre as coisas que preciso ouvir, você sabe exatamente o quê e quando preciso ouvi-las.

Obrigada por se importar comigo. E por dizer que me ama. Obrigada por continuar do meu lado quando estou chata e implicante.

Obrigada por não me ignorar quando estou insuportável. Obrigada por confiar em mim. Por contar comigo. Por me fazer sentir útil. Obrigada por tentar sempre me mostrar os caminhos certos e torná-los mais suaves. Obrigada por toda a ajuda que me dá desde o dia em que sai de seu ventre! Mãe, dou-te a palavra para te dizer o quanto te amo... Mãe, doute-a as minhas mãos para te afagar o rosto... Mãe, dou -te o meu colo para que possas descansar...

Mãe dou-te o meu coração para que possas morar nele.... para sempre...

Mãe, dou-te todos os dias da minha vida minha eterna gratidão Mãe... vencedores nunca desistem e quem desiste nunca vence... e com certeza nós duas juntas conseguimos vencer todos os obstáculos que a vida nos deu! Mãe... sou muito feliz por ser tua Fi Iha! 



\section{AGRADECIMENTOS ESPECIAIS}

A Deus,

... pelo dom da vida,

... por me presentear com a inteligência e o livre arbitrio;

... por colocar em minha vida pessoas tão especiais;

... por todas oportunidades concedidas;

... por me amparar em cada momento;

... por me abençoar em cada passo de minha vida;

... por renovar a cada dia minhas forças, para que eu possa transpor os obstáculos que se apresentam em meu caminho e suportar aqueles que são intransponiveis; ... por me fazer acreditar que tudo é possivel quando se tem fé! 

Agradeço as pessoas mais importantes de minha vida, onde sem elas não conseguiria alcançar meus objetivos!

\section{Ao meu amado vovô, José Julianelli}

Com todas as suas virtudes e também seus defeitos. Este homem com olhar austero, sempre pronto e atento, mostrando-me o caminho da vida, que está pela frente.

Este mestre e contador de fistórias

traz em seu coração tantas lembranças e memórias, espalha no meu caminhar muitas esperanças, certezas e confianças para um futuro.

Este homem alegre e brincalhão, às vezes, silencioso e pensativo, homem de fé e de grande responsabilidade e luta, sensivel, generoso e amigo de ajudar quem gosta. $O$ abraço aconchegante a me acolher, este homem, é você vovô, meu velho e grande amigão, conselheiro e amigo leal, infinito é teu coração. Fez papel de pai e de mãe, de avô e de avó, companheiro em toda minha vida, que me supriu com todas minhas necessidades, meu herói, com quem aprendo a viver! Obrigado, vozinho, por orientar o meu caminho, feito de lutas e incertezas, mas também de muitas esperanças, alegrias e sonhos! 

Meu amado tio, Mário Julianelli (in memorian)

Gostaria que estivesse ao meu lado neste momento tão importante da minha vida, o qual sem o senhor não seria possível chegar até aqui!

Voz de experiência que me inspirou na luta pelos meus ideais. Obrigada pelo exemplo de vida e por me fazer acreditar que nenhum obstáculo pode ser maior que a vontade de vencer! Quando fecho os olhos sinto sua presença constante em minha vida, sempre me auxiliando nos momentos mais difíceis.

Obrigada por tudo!

Minha amada tia, Maria de Lourdes Razeira Julianelli

Obrigada pelas orações, pelo carinho, preocupação, e também por estar sempre ao meu lado.

Obrigada pela dedicação e por todos os esforços em me proporcionar uma vida feliz.

Suas palavras me estimulam a seguir em frente e a acreditar num futuro abençoado. Agradeço a Deus por fazer parte da minha vida!

Agradeço vocês por tudo que me proporcionaram até hoje do fundo do meu coração! Amo vocês! 



\section{Meu amado pai, \\ $\mathcal{N} e l s o n$ Correia de Araújo}

"O milagre está nos detalhes do cotidiano; é preciso viver cada minuto, porque ali encontramos a saída para as nossas confusões, a alegria de nossos bons momentos, a pista certa para a decisão que precisa ser tomada"

Ao longo da minha caminhada tive que aprender não ter sua presença constante em minha vida, o que não foi fácil, mesmo porque, tínhamos um lanço de pai e filha muito grande. Mas a vida continuou e... Aprendi que sou fruto de uma linda fistória de amor...

Aprendi que nada é como a gente quer... Aprendi que nada, ninguém e nem a distância poderá separar nossas vidas... Obrigada pelos momentos felizes que me proporcionaste nestes anos que convivemos juntos!

Te amo muito! 



\section{AGRADECIMENTOS}

Ser Professor!

"É despertar a magia do saber é abrir caminhos de esperança desvendar o mistério do cálculo da fala e da escrita.

É criar o real desejo de ser.

É buscar dentro de cada um de nós forças para prosseguir, mesmo com toda pressão, toda tensão, toda falta de tempo.

É conhecer os limites do outro. E, ainda assim, acreditar que ele seja capaz...

É promover o saber universal especializar politicos, médicos, cientistas, técnicos, administradores, artistas...

$\dot{E}$ participar profundamente do crescimento social...

"É também reconhecer que somos, acima de tudo, seres humanos, e que temos licença para rir, chorar, esbravejar"

Ao meu orientador Prof. Dr. José Roberto de Magalhães Bastos

Se hoje estou aqui é porque me ensinou tantas coisas, ajudou-me dar tantos passos, me deu uma oportunidade e acreditou em mim e foi o grande incentivador deste mestrado.

Profissional exemplar, de extrema competência, agradeço pelo incentivo, pelos confiecimentos e pela confiança depositada em mim durante esses últimos anos. Tive uma oportunidade única, onde foi um grande aprendizado ser sua estagiária, aprendi muitas coisas que faculdade nenhuma poderia me propiciar.

Talvez ache que apenas fez o básico, mas para mim fez o essencial para que eu pudesse dar meus passos firmes.

Ensinou-me que cada pergunta pode ter mais de uma resposta, e que a resposta a escother é aquela que, mais nos faz bem.

É por tudo isso que estou aqui para dizer o quanto te admiro e agradecer por tudo o que me proporcionou! 

À Profa. Dra. Sílvia Helena de Carvalho Sales Peres,

por ter se disponibilizado em ser minha "co-orientadora", mesmo tendo muitos trabalhos em andamento, sempre me conduzindo para fazer o melhor!

Desde que a conheci esteve sempre disposta a auxiliar-me na realização de

diversos trabalhos. Mulher amiga, mãe dedicada, professora competente e exemplar, é assim que a vejo. Obrigada pela pessoa tão especial que é. Obrigada pela ajuda e paciência, fundamentais para realização deste trabalho. Obrigada por entender minhas dificuldades e sempre me propiciar algo melhor, por acreditar em mim, pela confiança depositada muitas vezes e principalmente pela sua amizade! Sinto uma pessoa privilegiada por poder contar com você. Agradeço a Deus por fazer parte da minha vida!

Ao Prof. Dr. Arsenio Sales Peres,

Pelos ensinamentos e oportunidades concedidos durante o mestrado, pelo apoio constante durante todo o curso, pela amizade e pelo exemplo de profissionale ser fumano a ser seguido.

Professor, o seu jeito de ensinar, me fez aprender muitas coisas, principalmente ser pontual.

Obrigada por tudo. Orgulho-me de ter sido sua aluna!

Ao Prof. Dr. José Roberto Pereira Lauris, pelas valiosas sugestões e enorme contribuição no exame de qualificação, pelo auxílio da análise estatística e pela paciência em me ensinar utilizar corretamente o programa estatístico.

Exemplo de pessoa e mestre!

A professora Profa. Dra. Magali de Lourdes Caldana,

Exemplo a ser seguido como pessoa e profissional, sempre atenciosa, meiga, gentil, carinhosa e educada comigo. Meu eterno carinho, respeito, admiração e gratidão. Obrigada por tudo! 

Á minha querida tia e amiga, Maria Cristina Morales, por compartilhar comigo os momentos de tristezas e também de alegrias, nesta etapa, em que, com a graça de Deus, esta sendo vencida.

Obrigada pelo apoio, carinho e atenção.

Amo você!

\section{Á minha querida amiga e psicóloga,}

Sandra M. Pirola Bezerra,

pela amizade, pela disponibilidade, pelo carinho e incentivos permanentes, pela dedicação e compreensão, em todos os momentos desta e de outras caminhadas.

Ao meu querido amigo, Ismar Eduardo Martins Fi Tho,

Fácilé ser colega, fazer companhia a alguém, dizer o que ele deseja ouvir...

Difícilé ser amigo para todas as horas e dizer sempre a verdade quando for preciso, mesmo que esta possa te magoar...

Conhecemos-nos há tanto tempo,

mas nos últimos quatro anos nossa amizade cresceu e aprendi a escutar quando era preciso e até seguir seus conselhos.

Às vezes você perdia a paciência comigo, pois sei que sou uma pessoa teimosa, mas depois tudo voltava ao normal.

Obrigada por me respeitar, me apoiar em minhas decisões, tanto na minha vida profissional como pessoal.

Obrigada por confiar em mim, compartilhar sua vida comigo e principalmente por me ajudar nas viagens de Ribeirão Preto.

Saiba que tenho um enorme carinho por você e estarei sempre aqui quando precisar! 

Á minha querida amiga, Suzana Goya

"Hfá pessoas que nos falam e nem as escutamos; há pessoas que nos ferem e nem cicatrizes deixam mas há pessoas que simplesmente aparecem em nossa vida e nos marcam para sempre"

(Cecília Meireles)

$\mathcal{N}$ essa nossa caminhada sua amizade foi muito importante para mim, mesmo nos momentos mais difíceis me fazia rir. Esteve presente em todas minhas dificuldades e soube levantar-me quando eu precisei! Sentirei saudades de todas as conversas jogadas fora, das descobertas que fizemos, de tantos risos e momentos alegres que passamos juntas!

Á minha querida amiga, Rute Moreira de Freitas Sant'anna

Você é um exemplo a seguir, sua energia nos radia, nos deixa mais alegres, nos contamina.

Sua capacidade de lidar com as pessoas é incrivel, sempre carinhosa, dedicada e preocupada com as pessoas ao seu redor. Sua presença na minha vida sempre será de grande valia. Obrigada por incentivar-me a nunca desistir. Muito obrigada por tudo. Sua amizade é uma Honra! 

Às minhas queridas amigas,

Melissa Thiemi Kato e Agnes de Fátima Pereira

Amigos sabem quando serão amigos, pois compartilham momentos, nos dão força...

Estão sempre lado a lado. NNas conquistas, nas derrotas, nas horas 6oas e nas difíceis também...

Amizade nem sempre é pensar do mesmo jeito, mas abrir mão de vez em quando... É compartilhar segredos e emoções...

É compreensão e diversão... É contar com alguém sempre que precisar... É ter algo em comum... É não ter nada em comum...

È sentir saudades...

Amizade que é amizade nunca acaba...

Mesmo que a gente creş̧a...

$\mathcal{E}$ apareçam outras pessoas no nosso caminho... Porque amizade não se explica...

Agradeço pelo apoio, pela atenção, pelo carinho e pelos momentos de desabafo. Adoro vocês!

Ao meu querido amigo, Sérgio Donha Yarid,

Foi um enorme prazer poder compartilhar minha vida com sua família, sinto muita falta da Yasmim pedindo para eu "Cimpar os dentinhos dela", sinto falta de ler a "revista caras" com a Cristina. Vocês sempre me acolheram e me apoiaram quando mais precisei. Vocês moram no meu coração. Obrigada por tudo! 

Aos amigos do mestrado, Agnes, Fernando, Gustavo, Henrique, Ismar, Thiemi, Sérgio, Suzana, Ricardo, Rute, Tatiane. Que trouxeram a minha vida muitos momentos de amizade e descontração, meus sinceros agradecimentos pela amizade e companheirismo durante todo curso.

\section{Á amiga, Fernanda Menechino Costa,}

por compartilhar momentos de alegrias, sentirei muita fala de nossas viagens, nossas conversas, nossos passeios, foi muito bom tê-la em minha vida.

Obrigada!

Ao meu amigo Maurício,

"Os anjos existem, mas algumas vezes não possuem asas e passamos a chamá-los de amigos"

Obrigada por ser tão atencioso e preocupado, pelo apoio e ombro amigo. Nunca imaginei ter amigos tão sinceros. Obrigada pela ajuda e paciência com minhas pacientes. Tenho um enorme carinho e respeito por você!

Aos funcionários do Departamento de Saúde Coletiva da FOB-USP, Silvia, Rosa, Marta e Helena, pela atenção e carinho durante todo o curso. Em especial a Rosinha, que desde o começo me estendeu seus braços, foi de grande valia seus conselhos e ensinamentos, realmente você é uma pessoa muito especial em minha vida, pelas nossas conversas, pela preocupação que sempre mostrou ter, enfim meu sentimento por você é como de filha, pode ter certeza que sempre estarei contigo!

Sílvia eu tenho muito que agradecer, quando entrei no departamento para ser estagiária, me lembro, que várias vezes você me conduzia em como proceder com algumas situações, foi grande seus ensinamentos, acabamos nos tornamos amigas e pode ter certeza que meu carinho por você é muito grande. Muito obrigada! 

Aos funcionários da Pós-Graduação, e do Serviço de Biblioteca da FOBUSP, por serem muito prestativos e estarem sempre dispostos a ajudar.

À Faculdade de Odontologia de Bauru, aos mestres e funcionários, por fazerem parte do meu processo de amadurecimento, formação de caráter e por ter permitido fazer parte do seu grupo discente.

Ao Hospital das Clínicas de Ribeirão Preto - SP, pela oportunidade de conviver e aprender com tão experientes profissionais.

Ao Prof. Dr. José Ernesto dos Santos, pessoa boníssima, generosa e acima de tudo mestre no sentido mais amplo da palavra.

À Profa. Dra. Rosane Pilot Pessa Ribeiro, pelo carinho e atenção com que sempre me atendeu, pela indispensável colaboração durante o desenvolvimento deste trabalho, pela cumplicidade, amizade.

Aos pacientes e seus responsáveis, pela colaboração e boa vontade, sem as quais este trabalho se tornaria inviável.

Impossivvel é deixar de agradecer a todos os que, de maneira direta ou indireta, foram de igual modo importantes, contribuindo com um sorriso, um olhar amigo, uma palavra de estímulo, mas que indubitavelmente, propiciaram-me condições de prosseguir e concluir este trabalho.

MUITO OBRIGADA!!! 



\section{SUMÁRIO}

LISTA DE ILUSTRAÇÕES

xxxv

LISTA DE TABELAS

LISTA DE ABREVIATURAS, SIGLAS E SÍMBOLOS

$x x x v i i$

RESUMO

xxxix

ABSTRACT

xliii

1 INTRODUÇÃO

xlvii

51

2 REVISÃO DE LITERATURA $\quad 57$

2.1 TRANSTORNOS ALIMENTARES 59

2.1.1 Epidemiologia $\quad 65$

$\begin{array}{lll}2.1 .2 & \text { Etiologia } & 67\end{array}$

$\begin{array}{lll}2.1 .3 & \text { Anorexia nervosa } & 70\end{array}$

$\begin{array}{lll}\text { 2.1.3.1 Definição } & 70\end{array}$

$\begin{array}{lll}\text { 2.1.3.2 Histórico } & 71\end{array}$

$\begin{array}{lll}2.1 .3 .3 & \text { Critérios diagnósticos } & 73\end{array}$

2.1.3.4 Aspectos clínicos e complicações sistêmicas $\quad 76$

2.1.3.5 Tratamento e prognóstico $\quad 80$

$\begin{array}{lll}2.1 .4 & \text { Bulimia nervosa } & 81\end{array}$

2.1.4.1 Definição $\quad 81$

2.1.4.2 Histórico $\quad 82$

2.1.4.3 Critérios diagnósticos $\quad 83$

2.1.4.4 Aspectos clínicos e complicações sistêmicas 85

2.1.4.5 Tratamento e prognóstico $\quad 89$

2.1.5 Transtorno de compulsão alimentar periódica 90

2.1.5.1 Definição 90

2.1.5.2 Histórico $\quad 91$

2.1.5.3 Critérios diagnósticos $\quad 92$

2.1.5.4 Aspectos clínicos e complicações sistêmicas 94

2.1.5.5 Tratamento e prognóstico $\quad 95$

2.1.6 Características odontológicas 96

2.1.6.1 Complicações clínicas em saúde bucal 96

2.1.6.2 Tratamento odontológico 99

2.2 DESGASTE DENTÁRIO 103

$\begin{array}{lll}2.2 .1 \text { Abfração } & 106\end{array}$

$\begin{array}{lll}2.2 .2 \text { Abrasão } & 109\end{array}$

$\begin{array}{lll}2.2 .3 \text { Atrição } & 113\end{array}$ 
$\begin{array}{lll}2.2 .4 & \text { Erosão } & 115\end{array}$

2.2.4.1 Erosão extrínseca 117

2.2.4.2 Erosão intrínseca 121

2.2.5 Índice de desgaste dentário 125

2.2.6 Estudos de prevalência do desgaste dentário em pacientes 130 com transtornos alimentares

3 PROPOSIÇÃO 135

4 MATERIAL E MÉTODOS 139

4.1 ASPECTOS ÉTICOS 139

4.2 EQUIPE MULTIPROFISSIONAL 140

4.3 COMPOSIÇÃO DA AMOSTRA 140

4.4 DELINEAMENTO DO ESTUDO 141

4.4.1 Calibração do examinador para avaliar desgaste dentário 141

4.4.2 Apresentação da cirurgiã-dentista ao GRATA e inserção do 142 cirurgião-dentista ao grupo de pacientes portadores de transtornos alimentares

4.4.3 Aplicação do questionário 142

4.4.4 Exame clínico 143

4.4.5 Códigos e critérios utilizados 145

$\begin{array}{lll}\text { 4.4.6 Análise estatística } & 148\end{array}$

5 RESULTADOS 151

5.1 CARACTERIZAÇÃO DA AMOSTRA 151

5.2 CONDIÇÕES DE DESGASTE DENTÁRIO 154

6 DISCUSSÃO 163

6.1 TRANSTORNOS ALIMENTARES 163

6.2 CONTRIBUIÇÃO DA ODONTOLOGIA PARA O ATENDIMENTO 164 DE PACIENTES COM TRANSTORNOS ALIMETARES

6.3 EQUIPE MULTIPROFISSIONAL - GRATA 165

6.4 PROBLEMAS BUCAIS EM PACIENTES COM TRANSTORNOS 166 ALIMENTARES

6.5 CONDIÇÕES DE DESGASTE DENTÁRIO 167

7 CONCLUSÕES 173

REFERÊNCIAS 177

ANEXOS 195

APÊNDICES 201 


\section{LISTA DE ILUSTRAÇÕES}

Figura 1 - Critérios diagnósticos para a anorexia nervosa segundo os sistemas de classificação DSM - IV e CID - 10

Figura 2 - Critérios diagnósticos para a bulimia nervosa segundo os sistemas de classificação DSM - IV e CID - 10

Figura 3 - Terminologia e definição dos diversos tipos de desgaste dentário 105

Figura 4 - Lesão de abfração ................................................................. 107

Figura 5 - Lesão de abfração ……….................................................... 107

Figura 6 - Lesão de abfração ............................................................. 107

Figura 7 - Lesão de abrasão .............................................................. 111

Figura 8 - Lesão de abrasão ........................................................... 111

Figura 9 - Lesão de abrasão ............................................................. 111

Figura 10 - Lesão de atrição ............................................................... 113

Figura 11 - Lesão de atrição ............................................................... 115

Figura 12 - Lesão de atrição ……….................................................... 115

Figura 13 - Lesão de erosão .............................................................. 115

Figura 14 - Lesão de erosão .............................................................. 119

Figura 15 - Lesão de erosão ............................................................. 119

Figura 16 - Lesão de erosão .............................................................. 119

Figura 17 - Lesão de erosão .............................................................. 119

Figura 18 - Lesão de erosão .............................................................. 123

Figura 19 - Lesão de erosão ............................................................... 123

Figura 20 - Mesa clínica ................................................... 143

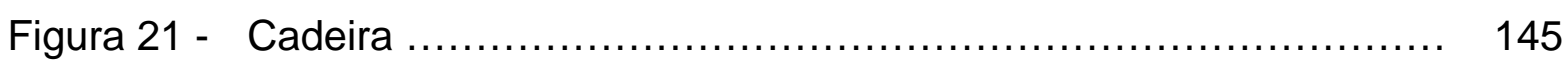

Figura 22 - Fonte de Luz artificial ........................................... 145

Figura 23 - Índice adaptado para Desgaste Dentário (IDD).......................... 147

Figura 24 - Percentual de desgaste dentário acometidos por indivíduos em pacientes com transtornos alimentares................................... 155

Figura 25 - Percentual de pacientes com bulimia nervosa em relação à severidade do desgaste dentário.

Figura 26 - Percentual de pacientes com anorexia nervosa tipo restritiva em relação à severidade do desgaste dentário. 
Figura 27 - Percentual de pacientes com anorexia nervosa tipo purgativa em relação à severidade do desgaste dentário................................. 156

Figura 28 - Percentual de desgaste dentário na superfície oclusal ................ 156

Figura 29 - Percentual de desgaste dentário na superfície vestibular ............. 157

Figura 30 - Percentual de desgaste dentário na superfície lingual/palatina.... 157

Figura 31 - Percentual de pacientes que deixam de realizar higiene bucal antes de dormir ………………....................................... 158 


\section{LISTA DE TABELAS}

Tabela 1 - Índice de desgaste dentário proposto por Ten Cate; Imfeld, em 1996.

Tabela 2 - Classificação da erosão dentária preconizada por Eccles, em 1979

Tabela 3 - Índice de desgaste dentário - (TWI - Tooth wear índex) proposto por Smith e Knight, em 1984.

Tabela 4 - Índice de erosão dental proposto por O’Brien, em 1994.

Tabela 5 - Índice de erosão dental proposto por O'Sullivan, em 2000.

Tabela 6 - Índice de desgaste dentário proposto por Sales Peres et al., em 2005.

Tabela 7 - Percentual de pacientes com transtornos alimentares por faixa etária.

Tabela 8 - Percentual do tipo de transtorno alimentar.

Tabela 9 - Número de pacientes com transtornos alimentares por nível de escolaridade.

Tabela 10 - Percentual de pacientes em relação à ocupação. 153

Tabela 11 - Percentual de pacientes em relação à renda familiar. 153

Tabela 12 - Porcentagem de pacientes em relação à procedência. 154 



\section{LISTA DE ABREVIATURAS, \\ SIGLAS E SIIMBOLOS}

ADA American Dietetic Association

AN Anorexia Nervosa

AN-R Anorexia Nervosa - Restritiva

AN-P Anorexia Nervosa - Purgativa

APA American Psychiatric Association

BN Bulimia Nervosa

CEP Comitê de Ética em Pesquisa

CID Classificação Estatística Internacional de Doenças e Problemas

Relacionados à Saúde

CT Colesterol Total

DD Desgaste Dentário

DSM Diagnostic and statistical manual of mental disorders

ECA Episódio de Compulsão Alimentar

GRATA Grupo de Assistência aos Transtornos Alimentares

HCFMRP Hospital das Clínicas da Faculdade de Medicina de Ribeirão Preto

IDD Índice de desgaste dentário

IMC Índice de Massa Corpórea

Kcal Calorias

$\mathrm{kg} / \mathrm{m}^{2} \quad$ Kilograma/metro quadrado

LNC Lesões não cariosas

mg Miligrama

n Número da amostra

OMS Organização Mundial da Saúde

p Nível de significância

$\mathrm{pH} \quad$ Potencial hidrogeniônico

SUS Sistema Único de Saúde 
TA Transtorno alimentar

TAs Transtornos alimentares

TCAP Transtorno de Compulsão Alimentar Periódica

TCLE Termo de Consentimento Livre Esclarecido

TWI Tooth Wear Índex

USP Universidade de São Paulo 


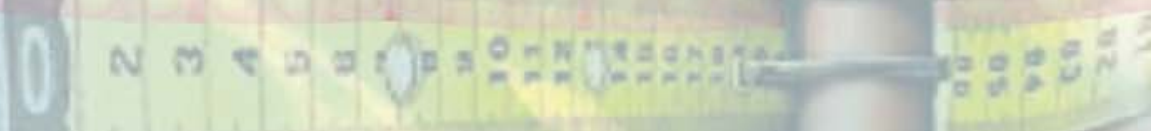

RESUMO 





\section{RESUMO}

Os transtornos alimentares são definidos como desvios do comportamento alimentar que podem levar à caquexia ou à obesidade, entre outros problemas físicos e incapacidades. Corresponde aos diagnósticos de Anorexia Nervosa (AN), Bulimia Nervosa (BN) e o Transtorno de Compulsão Alimentar Periódica (TCAP). Este estudo objetivou avaliar a prevalência e a severidade de desgaste dentário de pacientes atendidos pelo GRATA (Grupo de Assistência aos Transtornos Alimentares) do Hospital das Clínicas da Faculdade de Medicina de Ribeirão Preto - USP (HCFMRP - USP). A amostra foi composta por 30 pacientes com transtornos alimentares atendidos no GRATA. O instrumento de coleta de dados utilizado foi um questionário com perguntas estruturadas dividido em duas etapas: a primeira contendo informações relacionadas à identificação dos pacientes; a segunda parte para identificar hábitos presentes na rotina diária dos pacientes, abrangendo questões sobre cuidados com higiene bucal, hábitos bucais e alimentares, a fim de detectar as associações com os diferentes graus de desgaste dentário, utilizando o índice IDD adaptado. Procedeu-se a análise estatística por meio de freqüências absolutas e relativas. O teste de Mann Whitney $(p<0,05)$ foi utilizado para amostras independentes. Verificou-se neste estudo que todos os pacientes portadores de transtornos alimentares apresentaram algum grau de desgaste dentário, sendo que a superfície dentária mais acometida foi à superfície oclusal/incisal com uma severidade de desgaste dentário em dentina correspondendo a 66,7\%. Com relação à superfície vestibular observou-se que 13,3\% apresentaram desgaste dentário grau 4. Na superfície lingual apresentou uma prevalência de desgaste dentário com comprometimento pulpar de 13,4\%. O fator ranger e apertar os dentes apresentou-se uma associação significativa com o desgaste dentário na superfície oclusal $(p=0,02$ e $p=0,01$ respectivamente). Assim, concluiu-se que pacientes portadores de transtornos alimentares podem apresentar desgaste dentário em diferentes graus. O cirurgião-dentista pode contribuir no diagnóstico, na prevenção e no tratamento de alterações dentárias, proporcionando benefícios à saúde bucal e geral destes pacientes.

Palavras-chave: transtornos da alimentação, prevalência, erosão de dente. 

10) Nक

ABSTRACT 




\section{ABSTRACT}

\section{Evaluation of prevalence of tooth wear in patients with eating disorders}

Eating disorders are defined as deviations in eating habits that may lead to cachexy or obesity, besides other physical problems and inabilities. It corresponds to diagnoses of Anorexia, Bulimia and Binge Eating Disorder. This study evaluated the prevalence and severity of tooth wear in patients assisted at GRATA (Group of Assistance to Eating Disorders) of the Clinics Hospital of Ribeirão Preto Medical School - USP (HCFMRP-USP). The sample included 30 patients with eating disorders assisted at GRATA. Data were collected with aid of a questionnaire containing structured questions, divided into two sections; the first contained information related to patient identification, and the second aimed to identify habits in the daily routine of patients, including questions on oral hygiene, oral and feeding habits, to investigate the association with different degrees of tooth wear, using the adapted tooth wear index (TWI). The results were statistically analyzed by absolute and relative frequencies. The Mann Whitney test for independent samples was applied $(p<0.05)$. All patients with eating disorders in this study presented some degree of tooth wear; the occlusal/incisal tooth aspect was the most affected, with severity of tooth wear in dentine corresponding to $66.7 \%$. Concerning the buccal aspect, $13.3 \%$ exhibited some tooth wear degree 4 . The lingual surface presented prevalence of tooth wear with pulp involvement of $13.4 \%$. The habit of tooth clenching and grinding had significant association with tooth wear on the occlusal aspect ( $p=0.02$ and $p=0.01$, respectively). Thus, it was concluded that patients with eating disorders may present tooth wear of different degrees. The dentist may contribute with diagnosis, prevention and treatment of tooth alterations, providing benefits to the oral and general health of these patients.

Key words: eating disorders, prevalence, tooth erosion. 

1 INTTRODUÇÃO 



\section{INTRODUÇÃO}

Nas últimas décadas, em decorrência de fenômenos sociológicos e culturais, tem-se verificado um crescimento na incidência dos transtornos alimentares (TAs), constituindo-se um verdadeiro problema de saúde pública. Estes requerem à atenção dos profissionais da área da saúde por apresentarem significativos graus de morbidade e mortalidade (CASTRO; GOLDSTEIN ${ }^{46}$, 1995).

Os sentimentos de negação da própria condição patológica, muitas vezes, conseqüência de tabu existente em torno dos sintomas dos TAs, se estendem por um longo período de tempo sem serem diagnosticados, acarretando o aparecimento de co-morbidades e agravos à saúde (MAGALHÃES; MENDONÇA ${ }^{102}$, 2005).

O gênero feminino de uma maneira geral é muito vulnerável às pressões sociais, econômicas e culturais associado aos padrões estéticos. A sociedade rejeita, discrimina e reprova pessoas obesas, contudo muitas mulheres encontramse insatisfeitas com seu corpo. O medo de engordar faz com que um número cada vez maior de mulheres faça dieta, controle neuroticamente o peso corporal, exercitese de maneira exaustiva e faça uso de laxantes, diuréticos e drogas anorexígenas (FIATES; SALES ${ }^{62}, 2001$ ).

A preocupação exagerada na busca do corpo perfeito impulsiona uma parcela da sociedade na realização constante de regimes e uso indiscriminado de inibidores de apetite. Esses comportamentos servem como alerta para um problema mundial mais freqüente em mulheres adultas e jovens, entre 18 e 40 anos, afetando $3,2 \%$ desta população (COBELO ${ }^{49}, 2004 ;$ ADA $\left.^{8}, 2006\right)$.

Os TAs são quadros psiquiátricos caracterizados por alterações no hábito alimentar, associadas ou não a uma distorção no modo habitual de vivenciar a imagem corporal, que causam desconforto e/ou risco importante à saúde (LEITE; PINTO $^{92}$, 2001). Os tipos de TAs são: Anorexia Nervosa (AN), Bulimia Nervosa (BN) e recentemente uma terceira categoria vem sendo estudada, o Transtorno de Compulsão Alimentar Periódica (TCAP) (AZEVEDO19, 1996). 
A AN foi, no século XIX, o primeiro Transtorno Alimentar (TA) a ser descrito. Caracterizado por limitações dietéticas auto-impostas, padrões bizarros de alimentação com acentuada perda de peso induzida e mantida pelo paciente, associada a um temor intenso de engordar ou de tornar-se obeso, distorção grosseira da imagem corporal, negação da gravidade de sua condição nutricional e alterações do ciclo menstrual; amenorréia primária ou secundária (APA $\left.{ }^{9}, 1994\right)$.

Por outro lado, a BN é definida pela presença freqüente de compulsão alimentar, com ingestão, em um período curto de tempo (menor que 2 horas), de grande quantidade de alimento. Esses episódios são acompanhados de sentimento de perda de controle sobre a quantidade de alimentos ingeridos e seguidos freqüentemente de eventos compensatórios para prevenção do ganho de peso como vômitos provocados, uso de laxantes, diuréticos, inibidores de apetite, enemas, realização de exercícios excessivos, jejuns, etc. (ROMARO; ITOKAZU ${ }^{135}$, 2002).

O TCAP possui características semelhantes com BN e obesidade, a diferença é que neste transtorno não há eliminação forçada de alimentos para evitar ganho de peso (APPOLINÁRIO; CLAUDINO ${ }^{14}$, 2000). É uma atitude alimentar caracterizada pela ocorrência de episódios de comer grandes quantidades de comida em intervalos curtos de tempo, sensação de perda de controle sobre o ato de comer e, em seguida, arrependimento de ter comido, sendo que o indivíduo come mais rápido que o normal e perde o controle da quantidade ingerida (AZEVEDO; SANTOS; FONSECA $\left.{ }^{21}, 2004\right)$.

O modelo etiológico mais aceito atualmente para explicar a gênese e a manutenção dos TAs é o modelo multifatorial que se baseia na hipótese de que vários fatores biológicos, psicológicos e sociais estejam envolvidos, interrelacionando-se (APPOLINÁRIO; CLAUDINO $\left.{ }^{14}, 2000\right)$.

Os TAs vêm chamando cada vez mais a atenção dos profissionais da área da saúde, como médicos, psicólogos, nutricionistas e também os cirurgiõesdentistas, nos quais os dentes refletem o estado de saúde do paciente (LEITE; PINTO $^{92}$, 2001).

As complicações clínicas odontológicas mais freqüentes estão associadas aos hábitos purgativos, particularmente à indução voluntária de vômito. O ato de 
regurgitar provoca problemas dentários e o cirurgião-dentista é potencialmente o primeiro profissional de saúde a diagnosticar a doença, devido a perdas de substâncias dentárias, resultantes de um ambiente bucal cronicamente ácido, assim como a ingestão de substâncias ácidas. Tais perdas de substâncias dentárias são chamadas de erosão dentária (SEABRA et al. ${ }^{143}$, 2004).

Erosão dentária é definida como um tipo de desgaste dentário (DD) que se constitui na perda gradual, lenta e irreversível de estrutura dentária provocada por processos químicos sem envolvimento de microorganismos. A erosão dentária pode ser causada por uma série de fatores extrínsecos e intrínsecos (ECCLES ${ }^{56}, 1979$; MURAKAMI; CORRÊA; RODRIGUES ${ }^{116}$, 2006). Os fatores extrínsecos são resultados da ação de ácidos exógenos provenientes de medicamentos, meio ambiente e da dieta alimentar. O ácido gástrico que entra em contato com os dentes durante a regurgitação ou refluxo gástrico são fatores intrínsecos como resultado da ação do ácido endógeno (ECCLES ${ }^{56}$, 1979; BARATIERI $\left.{ }^{23}, 2001\right)$.

Contudo, outros tipos de desgaste dentário podem acometer o paciente portador de TA como, abrasão (perda da estrutura dentária por agente mecânico como escovação inadequada); abfração (perda da estrutura dentária resultado de repetidas flexões dentária causada pelo estresse oclusal) e atrição (perda da estrutura dentária causada por contato funcional ou parafuncional, incluindo a mastigação e o bruxismo).

Outras complicações bucais podem ser encontradas como: trauma na mucosa provocado por objetos utilizados para induzir o vômito, alargamento uni ou bi lateral da glândula parótida, geralmente assintomático, queilite angular por deficiência nutricional, aumento do risco de cárie e doença periodontal, devido à ingestão de anfetaminas e outras substâncias que provocam hipossalivação e xerostomia (PEGORARO; SAKAMOTO; DOMINGUES ${ }^{128}, 2000$ ).

Embora a literatura científica apresente vários estudos realizados com pacientes portadores de TAs, poucos incluem o cirurgião-dentista como membro da equipe multiprofissional. Sendo assim, buscou-se integrar o cirurgião-dentista à equipe multiprofissional, do GRATA (Grupo de Assistência aos Transtornos Alimentares) do Hospital das Clínicas da Faculdade de Medicina de Ribeirão Preto - 
USP (HCFMRP - USP), com o intuito de avaliar a prevalência e a severidade de desgaste dentário nos pacientes portadores de transtornos alimentares, proporcionando a integração dos cuidados odontológicos na rotina de atendimento da equipe multiprofissional. 
2 REVISÃO DE LITERATURA 



\section{REVISÃO DE LITERATURA}

Com a finalidade de tornar este capítulo mais didático, ele foi dividido em dois tópicos: transtornos alimentares e desgaste dentário respectivamente onde irão abordar os seguintes itens:

2.1 TRANSTORNOS ALIMENTARES

\subsubsection{Epidemiologia}

\subsubsection{Etiologia}

\subsubsection{Anorexia Nervosa}

\subsubsection{Definição}

\subsubsection{Histórico}

2.1.3.3 Critérios diagnósticos

2.1.3.4 Aspectos clínicos e complicações sistêmicas

2.1.3.5 Tratamento e prognóstico

\subsubsection{Bulimia Nervosa}

2.1.4.1 Definição

2.1.4.2 Histórico

2.1.4.3 Critérios diagnósticos

2.1.4.4 Aspectos clínicos e complicações sistêmicas

2.1.4.5 Tratamento e prognóstico

\subsubsection{Transtorno de Compulsão Alimentar Periódica}


2.1.5.2 Histórico

2.1.5.3 Critérios diagnósticos

2.1.5.4 Aspectos clínicos e complicações sistêmicas

2.1.5.5 Tratamento e prognóstico

\subsubsection{Características odontológicas}

2.1.6.1 Complicações clínicas na saúde bucal

2.1.6.2 Tratamento odontológico

2.2 DESGASTE DENTÁRIO

2.2.1 Abfração

2.2.2 Abrasão

2.2.3 Atrição

2.2.4 Erosão

2.2.4.1 Erosão extrínseca

2.2.4.2 Erosão intrínseca

2.2.5 Índice de desgaste dentário

2.2.6 Estudos de prevalência do desgaste dentário em pacientes com transtornos alimentares 


\subsection{TRANSTORNOS ALIMENTARES}

Até o século $X V I$, cada indivíduo se alimentava conforme a disponibilidade de alimentos da região de onde habitava. Foi na França, com o início das práticas culinárias francesas que esse hábito começou a ser mudado, valorizando-se o sabor e o prazer. Assim, o entendimento da alimentação contempla um contexto muito mais amplo: o alimento pode ser vício, carícia ou refúgio. A partir daí, pode-se pensar como se faz o uso da comida (ALVARENGA $\left.{ }^{7}, 2003\right)$.

A alimentação é uma necessidade humana vital, onde a comida e o ato de se alimentar representam elementos de interação familiar e social, com conotações simbólicas (SANTACRUZ $\left.{ }^{140}, 1997\right)$.

O comportamento alimentar é um fenômeno complexo que vai alem do ato de comer, o qual transcende o valor nutritivo e as características sensoriais do alimento, possuindo motivações ocultas relacionadas às carências psicológicas e às vivências emotivas e conflituosas que independem da fome (ALVARENGA ${ }^{7}, 2003$; SANTACRUZ $\left.{ }^{140}, 1997\right)$.

Os alimentos são mais do que fonte de nutrição; eles assumem vários papéis nas sociedades humanas e estão profundamente vinculados aos aspectos sociais, religiosos e econômicos da vida cotidiana; a alimentação é parte essencial do modo como as sociedades se organizam (BUSSE $\left.{ }^{40}, 2004\right)$.

Como o alimento é o responsável direto pela manutenção do nosso corpo e não somente pela saúde é importante entender porque ele se tornou ameaçador, quando utilizado de maneira inadequada (CORDÁS; BUSSE $\left.{ }^{51}, 1995\right)$.

A sociedade atual valoriza demais o ato de comer, o almoçar fora ou o convite de amigos para um jantar, tornando a alimentação muito importante socialmente. A comida passou a ser utilizada como uma troca de mensagens com o ambiente: come-se para mostrar, provar, evitar, controlar, reprimir algo. E cada aspecto dessa atividade sustenta uma enorme indústria de consumo. Há alimentos para bebês, para crianças, refeições rápidas, alimentos integrais e, os light e diet $\left(\right.$ KAUFMAN $\left.^{86}, 2000\right)$. 
Ao longo dos séculos, os padrões de beleza feminina mudaram. Nos anos 80 , ocorreu um crescimento considerável do mercado relacionado à manutenção do corpo. Fazem parte desse arsenal industrial da sociedade de consumo, aparelhos de musculação, suplementos nutricionais, revistas sobre boa forma e saúde, regimes alimentares e cirurgia plástica (MORGAN; AZEVEDO ${ }^{112}$, 1998).

O homem contemporâneo mudou seus conceitos de beleza, passando a valorizar o corpo cada vez mais magro, atlético e torneado, ao invés do corpo cultuado no período renascentista, cheio de curvas, vislumbrado do passado (CORDÁS $\left.{ }^{50}, 2004\right)$.

Atualmente, ao mesmo tempo em que se observa uma oferta abundante de alimentos de alto teor energético e de rápido consumo, a vida cotidiana é cada vez mais sedentária, tornando mais penosa à tarefa de manter o corpo magro. Modelos e atrizes de sucesso, representantes dos padrões ideais de beleza feminina, são extremamente magras e muitas vezes apresentam um corpo de préadolescente com formas pouco definidas (NUNES et al. $^{118}, 1998$ ).

A ênfase da sociedade contemporânea no ideal de magreza (culto ao corpo), as intensas propagandas na mídia de uma infinidade de regimes e de produtos dietéticos, bem como o crescimento de academias e do número de revistas sobre o assunto, fornece o ambiente sociocultural que justifica a perda de peso, trazendo consigo uma simbologia de que a beleza física proporcionaria autocontrole, poder e "modernidade". Contudo, essa imagem corporal idealizada é um padrão impossível ou impróprio, incompatível para a grande maioria da população (SOUTO; FERRO-BUCHER ${ }^{153}$, 2006).

A sociedade valoriza a feminilidade, associa o sucesso à magreza em particular, e faz da obesidade uma condição estigmatizada. A associação da beleza, sucesso e felicidade com um corpo magro têm levado as pessoas à prática de dietas abusivas e de outras formas não saudáveis de regular o peso (KILLEN et al. ${ }^{87}$, 1993).

Atualmente, observam-se o crescimento de dietas e de transtornos alimentares, o que representa individualmente, insegurança e insatisfação quanto ao corpo, condições que prevalece nos dias atuais. A prática de dietas representa um 
risco para o desenvolvimento de TAs até 18 vezes maior, portanto essa conduta não deve ser estimulada indiscriminadamente (MORGAN; AZEVEDO ${ }^{112}$, 1998; CAMPOS $^{43}$, 2002; SOUTO; FERRO-BUCHER ${ }^{153}$, 2006).

A literatura científica na área de TAs vem apontando para um aparente aumento de sua ocorrência (LUCAS, et al. ${ }^{98}$, 1991; BRYANT-WAUGH; LASK ${ }^{37}$, 1995; HOEK; HOEKEN ${ }^{81}, 2003$; BUSSE; SILVA $\left.{ }^{41}, 2004\right)$.

O aumento significativo da incidência dos TAs estaria relacionado a esse contexto sociocultural específico em que o corpo é exposto e sua imagem, supervalorizada, de acordo com os padrões estéticos vigentes, em especial os do mundo da moda, da televisão e do cinema (BUSSE; SILVA $\left.{ }^{41}, 2004\right)$.

Os TAs são quadros psiquiátricas que afetam principalmente adolescentes e adultos jovens (embora uma procura maior de crianças se faça notar recentemente), levando a importantes complicações nutricionais, psicológicas, fisiológicas e sociais, além de aumento de morbidade e mortalidade ( ADA $^{8}, 2006$; PINZON; NOGUEIRA ${ }^{130}$, 2004; CORDAS; CLAUDINO ${ }^{52}$, 2002).

Segundo CORDÁS; CLAUDINO ${ }^{52}$, 2002, os TAs são freqüentemente considerados quadros clínicos ligados à modernidade. São síndromes comportamentais cujos critérios e diagnósticos têm sido amplamente estudados nos últimos 30 anos. Por ainda não se conhecer bem sua etiopatogenia são descritos como transtornos e não como doenças (CLAUDINO; BORGES ${ }^{48}$, 2002).

Nas últimas décadas, aparentemente em decorrência de fenômenos sociológicos e culturais, tem-se verificado um crescimento importante na incidência dos TAs, principalmente nos países ocidentais desenvolvidos. Em alguns deles, estatísticas apontam para uma incidência variável de 0,5\% a 5\% entre os adolescentes, constituindo-se em verdadeiro problema de saúde pública. Aproximadamente $90 \%$ dos acometidos são do gênero feminino, e a faixa etária de maior risco situa-se entre os 12 e os 25 anos de idade, sendo que indivíduos envolvidos em atividades que exigem manutenção da forma física estão sob maior risco para o desenvolvimento desses quadros (BASDEVANT et al. ${ }^{27}, 1995$ ). 
O impacto que os TAs exercem sobre as mulheres é mais prevalente, ainda que a incidência masculina esteja aumentando assustadoramente, ocorrendo em indivíduos de todas as classes socioeconômicas. As formas subclínicas são mais observadas do que as síndromes completas. Muito embora sejam reconhecidos como condições clínicas graves, associados a uma alta taxa de mortalidade, se distribuem como um espectro que vai de formas agudas até formas crônicas (APPOLINÁRIO; CORDÁS; CLAUDINO ${ }^{15}, 2002$ ).

No Brasil a área de TA também tem tido destaque crescente, derrubando mais um dos antigos preconceitos acerca da inexistência de tais quadros em países em desenvolvimento. Na última década, observamos o surgimento e o crescimento de grupos dedicados ao atendimento e a pesquisa de pacientes com transtornos alimentares em várias cidades brasileiras, possibilitando a formação de profissionais com habilitação mais específica (APPOLINÁRIO et al. ${ }^{17}$, 2002).

Os transtornos alimentares são definidos como desvios do comportamento alimentar que podem levar à caquexia ${ }^{1}$ ou à obesidade, entre outros problemas físicos e incapacidades. Esses correspondem basicamente aos diagnósticos de $\mathrm{AN}$ e BN, que se acham intimamente relacionados por apresentarem psicopatologia comum: uma idéia prevalente envolvendo a preocupação excessiva com o peso e a forma corporal expresso como um "medo mórbido de engordar" (GARFINKEL ${ }^{66}$, 1995). Os pacientes em ambos os quadros estabelecem um julgamento de si mesmos inadequados baseados na forma física, a qual é percebida freqüentemente de forma distorcida (APA $\left.{ }^{9}, 1994\right)$.

A freqüência e a constância com que ocorrem os transtornos alimentares são relevantes. Para que seja considerado como um transtorno, os episódios precisam repetir-se pelo menos duas vezes por semana, durante três meses. Se o quadro não se prolongar pelo período mínimo de tempo definido no DSM-IV ${ }^{9}$, manual de classificação diagnóstica das desordens mentais, organizado pela Associação Psiquiátrica Americana, trata-se apenas de episódios esporádicos, onde qualquer pessoa está sujeita (CAMPOS $\left.{ }^{43}, 2002\right)$.

\footnotetext{
${ }^{1}$ É a perda de peso, estado de desnutrição profunda que acompanha má condição geral de saúde, atrofia muscular, fadiga, fraqueza e perda de apetite por alguém que não está tentando perder peso. Pode ser um sinal médico de diversos distúrbios; quando um paciente apresenta caquexia, o médico geralmente considera a possibilidade de câncer, e algumas doenças infecciosas (como tuberculose, AIDS e alguns distúrbios autoimunes).
} 
Os atuais sistemas classificatórios de transtornos mentais, DSM-IV ${ }^{9}$ (Diagnostic and Statistical Manual IV edition) e CID $10^{124}$ (Classificação Internacional de Doenças, $10^{\mathrm{a}}$ edição), relacionam a $\mathrm{AN}$ e a $\mathrm{BN}$ como os principais transtornos alimentares e recentemente surge o terceiro diagnóstico; TCAP $\left(\mathrm{OMS}^{124}, 1993\right.$; APA $^{10}, 2000$; CLAUDINO; BORGES ${ }^{48}, 2002$ ).

Os TAs são acompanhados de várias complicações clínicas relacionadas ao comprometimento do estado nutricional e às práticas compensatórias inadequadas para o controle do peso (vômitos, uso de diuréticos, enemas ${ }^{2}$ e laxativos). Muitas destas complicações surgem em decorrência do atraso no diagnóstico e no início do tratamento, pois, muitos pacientes escondem os sintomas e/ou recusam o tratamento (ASSUMPÇÃO; CABRAL ${ }^{18}$, 2002).

Várias complicações médicas podem surgir em decorrência da desnutrição e dos comportamentos purgativos, tais como anemia, alterações endócrinas, osteoporose e alterações hidroeletrolíticas (especialmente hipocalemia, que pode levar a arritmia cardíaca e morte súbita), dentre outras. As alterações bucais mais encontradas são erosão dentária, aumento nos índices de cáries, intumescimento das glândulas salivares, sobretudo da parótida; alterações na quantidade (xerostomia) e qualidade (capacidade tampão) da saliva; queilite/mucosite; bruxismo e alterações ortodônticas (PEGORARO; SAKAMOTO; DOMINGUES $^{128}$, 2000).

O cirurgião-dentista pode ser o profissional a detectar a ocorrência de TAs pela possibilidade de se diagnosticar diversas manifestações bucais destes distúrbios de alimentação durante um exame odontológico rotineiro e encaminhar o paciente a uma equipe multidisciplinar. Assim, o paciente poderá ser abordado de uma forma precoce, cautelosa, gradativa e integral (XIMENES $\left.{ }^{171}, 2002\right)$.

\footnotetext{
${ }^{2}$ É a introdução de água ou qualquer outro líquido no intestino através do ânus. Pode ser feito com fins medicinais (como tratamento, preparo para procedimentos médicos, exame diagnóstico ou como a modalidade de medicina alternativa denominada hidrocolonterapia), por higiene ou ainda por estímulo sexual.
} 
É de primordial importância o papel do cirurgião-dentista frente ao diagnóstico de casos de transtornos alimentares de ordem comportamental como a bulimia nervosa e anorexia nervosa devido à existência de lesões dentais erosivas resultantes de um ambiente bucal ácido, bem como o encaminhamento destes pacientes para tratamento interdisciplinar que inclui terapeutas, médicos, nutricionistas e o próprio cirurgião-dentista (SANTOS; BARBOSA ${ }^{141}$, 2004).

A associação dos transtornos alimentares com outros quadros psiquiátricos é muito freqüente, especialmente com transtornos do humor, transtornos de ansiedade e/ou transtorno de personalidade, mesclando os seus sintomas com os da condição básica o que complica a evolução clínica (SMITH ${ }^{152}$, 1992).

Os TAs são síndromes psiquiátricas complexas e ainda pouco compreendidas, sobretudo na adolescência, quando freqüentemente se iniciam e afetam ampla e severamente o desenvolvimento do indivíduo. Apresentam prognósticos reservados e, caracteristicamente, envolvem a família (PINZON ${ }^{130}$, 2004).

É de suma importância que a família seja parte integrante no tratamento multidisciplinar dos pacientes, onde podem estar contribuindo, de modo significativo, no desenvolvimento ou na manutenção dos transtornos alimentares (COBELO ${ }^{49}$, 2004).

O tratamento de pacientes com TAs sofreu avanços nas últimas décadas. Os melhores resultados poderão ser alcançados através de ambulatórios de saúde específicos criados para o tratamento desses pacientes com equipes multiprofissionais, onde diferentes áreas da saúde estarão interagindo para oferecer o melhor atendimento ao indivíduo e poderão atuar no campo da prevenção, identificando os indivíduos em risco (PIRAN $\left.{ }^{131}, 1997\right)$. 


\subsubsection{Epidemiologia}

Os TAs vêm despertando maior atenção dos profissionais da área de saúde devido ao crescente aumento de sua prevalência nos últimos anos. O aumento no número de casos tem sido observado em homens e mulheres de todas as idades. De acordo com vários autores, a prevalência desses transtornos fica entre 1 e 4\%, afetando principalmente mulheres jovens entre 18 e 30 anos de idade (WILLI; GROSSMAN ${ }^{170}$, 1983; SZMUKLER ${ }^{159}$, 1985; ABOTT et al. ${ }^{1}$, 1993; MORANDÉ, CELADA; CASAS ${ }^{111}$, 1999; POP-JORDANOVA ${ }^{132}$, 2000; JONES et al. $^{84}$, 2001; FAIRBURN; HARRISON ${ }^{61}$, 2003; AMIGO $^{12}$, 2005; ADA $^{8}$, 2006).

Cerca de 90\% dos pacientes são do sexo feminino, com uma incidência maior nos indivíduos de raça branca e pertencentes à classe socioeconômica média e alta $\left(\right.$ AMIGO $\left.^{12}, 2005\right)$.

A taxa exata de TA no gênero masculino ainda não foi completamente estabelecida, até porque os homens são excluídos de muitos estudos em razão do baixo número de casos. Aproximadamente, $10 \%$ dos pacientes atendidos por profissionais de saúde são homens. Essa grande diferença, pode se dever ao fato de que homens parecem ser menos sujeitos a procurar tratamento para um transtorno alimentar do que as mulheres. Alguns grupos de homens apresentam uma incidência maior para desenvolver TA, principalmente os homossexuais. Podem-se destacar aqueles cujas profissões estão ligadas a uma preocupação exagerada com o peso ou a forma corporal - bailarinos, modelos, jóqueis, ginastas, nadadores, fisiculturistas, corredores e lutadores de luta livre (CARLAT; CAMARGO ${ }^{44}$, 1991; FAIRBURN; HARRISON ${ }^{61}$, 2003).

A incidência de TAs em atletas dos gêneros feminino e masculino é de 10 a 20\%. Mulheres atletas de modalidades como ginástica olímpica, corridas de longa distância e balé, assim como homens atletas em modalidades como lutas e fisiculturismo estão mais propensos a desenvolverem um TA (APA $\left.{ }^{11}, 2006\right)$.

A prevalência da AN é de 0,3\%. Síndromes parciais, com tendência a AN, ou seja, pacientes que não apresentam o transtorno totalmente desenvolvido, porém com a falta de pelo menos um critério diagnóstico para caracterizá-la, como, 
presença de ciclos menstruais e/ou perda de peso não esperada, ocorrem de 0,37\% a 1,3\% da população (HOEK; VAN HOEKEN ${ }^{81}, 2003$; BULIK et al. ${ }^{38}$, 2005).

A prevalência de $B N$ é de 1,0 a 4,2\%. A incidência média anual na população em geral de AN, entre mulheres, é de aproximadamente 18,5 por 100 mil e, entre homens, menos de 2,25 por 100 mil ao ano. Quanto à incidência de BN, os números são mais elevados, sendo 28,8 em 100 mil mulheres e 0,8 em 100 mil homens por ano. Em relação à BN o curso e a evolução parecem ser mais favoráveis comparadas à AN. De forma geral, entre os pacientes que receberam tratamento, 50\% apresentam bons resultados e os mantêm, enquanto 30\% mantêm síndromes parciais $\left(\mathrm{HAY}^{75}, 2002 ; \mathrm{APA}^{11}, 2006\right)$.

As taxas de morbidade e mortalidade dos TAs são expressiva, especialmente da AN que apresenta maior taxa de mortalidade dentre todos os distúrbios psiquiátricos, cerca de 9,8\% e o prognóstico da AN parece não ter melhorado durante o século 20. Pacientes do gênero feminino com AN parecem ter 12 vezes mais chances de morrer do que mulheres da população geral com a mesma idade. As principais causas de morte são: complicações cardiovasculares, insuficiência renal, suicídio e complicações relacionadas à desnutrição (ASSUMPÇÃO; CABRAL ${ }^{18}, 2002 ;$ APA $^{11}, 2006$ ).

Estudos epidemiológicos demonstram a prevalência do TCAP em 2\% da população em geral e em cerca de $30 \%$ de obesos que procuram tratamentos especializados. O TCAP está presente em todas as raças e distribui-se de maneira aproximada entre mulheres e homens, na proporção de 3:2 (APA ${ }^{11}, 2006$; STUNKARD; ALLISON ${ }^{158}$, 2003).

Estimativas recentes de prevalência do TCAP na população americana indicam que $2 \%$ a $3 \%$ dos adultos em amostras comunitárias são portadoras do comer compulsivo. No Brasil, estudos demonstraram uma prevalência entre 15\% e $22 \%$ em pacientes que procuravam tratamento para emagrecer (APPOLINÁRIO ${ }^{13}$, 2000; BORGES ${ }^{33}$, 1998; COUTINHO $\left.{ }^{53}, 2000\right)$. 
Aproximadamente $20 \%$ das pessoas que se identificam como possuidoras de compulsão alimentar possuem diagnóstico de TCAP (NAPOLITANO; HEAD; BABYAK $^{117}$, 2001; STUNKARD; ALLISON ${ }^{158}$, 2003).

\subsubsection{Etiologia}

Os TAs possuem uma etiologia multifatorial, não havendo um fator único causador ou responsável pela deflagração e manutenção desses transtornos. A interação complexa de fatores biológicos, genéticos, psicológicos, socioculturais e familiares determina seu aparecimento e perpetuação. O mecanismo multifatorial dos transtornos alimentares é dividido em três fatores: os fatores predisponentes, que aumentam as chances do aparecimento de um TA, os fatores precipitantes, que marcam o início do TA, e os fatores mantenedores, que contribuem para a instalação e perpetuação do TA (CORDÁS ${ }^{50}$, 2004; MORGANA; VECCHIATTIA; NEGRÃO ${ }^{113}$, 2002).

Fatores predisponentes:

- Biológicos: a tendência à obesidade pode aumentar a pressão sociocultural pela magreza, afetar a auto-estima e aumentar a prática de dietas restritivas, causando a vulnerabilidade para o aparecimento de um TA (WADDEN, et al. $\left.{ }^{168}, 2004\right)$;

- Familiares: dinâmicas familiares disfuncionais marcadas por superproteção, rigidez extrema e tendência a evitar conflitos na AN e desorganização, falta de afetos e cuidados na BN são comumente observadas. Outro fator bastante comum em famílias de pacientes com TA são mães extremamente críticas e preocupadas com aparência física e peso corporal, que apresentam uma relação complicada com os alimentos e não raro possuem TA ou características de um TA. Filhos de mães com TA possuem mais de $50 \%$ de chance de desenvolver um transtorno psiquiátrico (COBELO $\left.{ }^{49}, 2004\right)$; 
- Genéticos: os TAs e outros transtornos psiquiátricos, como depressão e abuso de substâncias, são comuns em uma mesma família. Porém, ainda é incerto o tamanho da contribuição da genética para o desenvolvimento dos mesmos (FAIRBURN; HARRISON ${ }^{61}$, 2003);

- Neurológicos: alterações nos sistemas de neurotransmissão são freqüentes em pacientes com TA. Pesquisas apontam o sistema serotoninérgico como importante regulador do comportamento alimentar, no controle do humor, do impulso e da obsessão nos transtornos, juntamente com o sistema noradrenérgico (NUNES et al. $\left.{ }^{119}, 2006\right)$;

- Personalidade: traços comuns na AN são os obsessivos, perfeccionistas, dificuldade em expressar sentimentos e introversão. Em relação à BN, traços impulsivos, instabilidade afetiva e sociabilidade são comuns. Baixa autoestima é um fator de risco comum na AN e na BN (MORGANA; VECCHIATTIA; NEGRÃO $\left.{ }^{113}, 2002\right)$;

- Socioculturais: Mudanças na disponibilidade e no significado dos alimentos, mudanças no conceito de beleza e supervalorização da magreza têm sido discutidos e considerados parte importante na etiologia dos TAs. A visão do alimento, unicamente, como fonte de energia e nutrientes tornou obsoleta sua importância emocional e social na vida das pessoas. Ao mesmo tempo, crianças e adolescentes ocidentais aprendem que magreza é sinônimo de sucesso, autocontrole, competência e atratividade sexual, o que leva a mudanças no comportamento alimentar buscando se enquadrar nos padrões. O paradoxo é que apesar da idealização da magreza e da grande oferta de dietas, tratamentos e cirurgias para emagrecer, a disponibilidade de comidas saborosas e calóricas aumenta continuamente (MORGANA; VECCHIATTIA; NEGRÃO ${ }^{113}, 2002$; ALVARENGA $^{7}, 2003$; NUNES et al. $\left.{ }^{119}, 2006\right)$.

- Outros: experiências adversas, como abuso sexual, trauma e estímulos negativos, como comentários depreciativos, recebidos ao longo do desenvolvimento, podem ser fatores importantes na etiologia dos TA (NUNES et al. ${ }^{119}, 2006$ ). 
Fatores precipitantes:

- Dieta para perda de peso: geralmente o principal fator desencadeante. A prática de dietas é um comportamento comum, aceito e estimulado pelas sociedades ocidentais. Dietas restritivas aumentam em 18 vezes o risco relativo de desenvolver um TA, enquanto dietas moderadas aumentam em 5 vezes o risco relativo de desenvolver um TA (HETHERINGTON ${ }^{80}, 2000$ );

- Situações como perdas, separações, doenças, gravidez etc. podem corroborar para o aparecimento de um TA, por provocar desorganização e reforçar sentimentos de insegurança e insatisfação (CORDÁS ${ }^{50}$, 2004; MORGANA; VECCHIATTIA; NEGRÃO $\left.{ }^{113}, 2002\right)$.

Fatores mantenedores:

- alterações neuroendócrinas, em decorrência da privação alimentar;

- distorção da imagem corporal;

- distorções cognitivas;

- práticas purgativas;

- alterações psicológicas;

- socioculturais (CORDÁS ${ }^{50}$, 2004; MORGANA; VECCHIATTIA; NEGRÃO ${ }^{113}$, 2002). 


\subsubsection{Anorexia nervosa}

\subsubsection{Definição}

Etimologicamente, a palavra anorexia origina-se do grego (an= deficiência ou ausência e orexis= desejo ou apetite). Na AN esse termo não deve ser utilizado em seu sentido etimológico, uma vez que a recusa e controle da ingestão dos alimentos têm como objetivo perder peso ou o medo de ganhá-lo sem, necessariamente, apresentar real perda de apetite (CORDÁS; CLAUDINO ${ }^{52}$, 2002).

A AN é um distúrbio de comportamento conceituado como inanição deliberada e auto-imposta, caracteriza-se por uma perda de peso acentuada e intencional em conseqüência de dietas extremamente restritivas, por uma percepção distorcida da imagem corporal, por um medo intenso de ganho de peso e por ausência de ciclos menstruais regulares (CASTRO; GOLDSTEIN ${ }^{46}$, 1995; CORDÁS $\left.^{50}, 2004\right)$.

$\mathrm{Na}$ sua forma típica, a AN se inicia geralmente na infância ou adolescência. O início é marcado por uma restrição dietética progressiva com a eliminação de alimentos considerados "engordantes", como os carboidratos. As pacientes passam a apresentar certa insatisfação com os seus corpos assim como passam a se sentir obesas apesar de muitas vezes se encontrarem até emaciadas (alteração da imagem corporal). O medo de engordar é uma característica essencial, servindo muitas vezes como um diferencial para outros tipos de anorexia secundária a doenças clínicas ou psiquiátricas. Gradativamente, as pacientes passam a viver exclusivamente em função da dieta, da comida, do peso e da forma corporal, restringindo seu campo de interesse e levando ao isolamento social. O curso desse transtorno é caracterizado por uma perda de peso progressiva e continuada. $\mathrm{O}$ padrão alimentar vai se tornando cada vez mais secreto e muitas vezes até assumindo características ritualizadas e bizarras. (APPOLINÁRIO ${ }^{13}$, 2000).

O papel da nossa cultura, valorizando o corpo delgado da mulher, esta ligado ao aumento da ocorrência da AN. Apesar de não haver dúvidas quanto a importância dos fatores culturais, especialmente o culto à magreza, devemos 
lembrar que a AN foi descrita pela primeira vez em uma época em que o estereótipo da beleza feminina não era o corpo delgado de hoje (VILELA et al. ${ }^{167}$, 2004).

\subsubsection{Histórico}

A AN já era um transtorno conhecido em épocas antigas. Entre os séculos V e XIII, o jejum voluntário ou inanição auto-imposta foram compreendidas como estados de possessão demoníaca ou milagres divinos. Foram descritos casos na vida de algumas santas da Igreja Católica, como, Lidwina (Lydwine) de Shiedam, uma santa do século XIV que viveu na Holanda. Um dos mais antigos relatos é o de Santa Wilgefortis ou santa do século XIV, nos anos de 700-900 D.C. Essa princesa, filha de um rei de Portugal, teria feito voto de castidade e prometera servir a Deus quando seu pai lhe prometera em casamento para um rei da Sicília. Sabendo disso, desejou a privação de sua beleza para perder seus atrativos femininos, praticando inanição auto-imposta, para que seu pretendente desistisse do casamento. Ela tornou-se assim, santa padroeira das mulheres que almejavam se livrar do assédio dos homens e do controle de outras pessoas (CORDÁS; CLAUDINO ${ }^{52}$, 2002).

BELL ${ }^{31}, 1985$, descreveu o comportamento anoréxico realizado por 260 santas italianas (que teriam vivido entre 1200 e 1600) aparentemente em resposta à estrutura patriarcal a qual estavam submetidas sendo conhecida como "anorexia sagrada". Pela supressão de necessidades físicas e sensações básicas (como cansaço, impulso sexual, fome e dor) elas pareciam liberar o corpo e alcançar metas espirituais superiores, porém às crenças religiosas pareciam se misturar a outras intenções das jovens, como a perda dos atrativos femininos. A mais famosa anoréxica da história é Santa Catarina de Siena, que jejuava por semanas, aos 7 anos começou a recusar os alimentos, e aos 15 anos, após a morte de sua irmã e diante de projetos futuros de casamento, iniciou restrição alimentar, só se alimentava de pão e ervas, chegando a induzir vômito através de ervas e galhos na garganta quando forçada a alimentar-se. Catarina havia feito um voto de castidade quando ainda era criança. A inanição haveria gerado um estado psicológico de constante vigília e experiências místicas, vindo a falecer de desnutrição aos 32 anos. 
No século IX em Avicena, o príncipe Hamadham estava morrendo por não se alimentar, vitima de uma imensa melancolia. Esta é a primeira referencia de um anoréxico em um contexto médico, ainda que proveniente de um quadro depressivo (NUNES et al. $\left.{ }^{118}, 1998\right)$.

O primeiro relato médico de Anorexia Nervosa foi descrito por MORTON ${ }^{114}$, 1694. O autor comenta sobre a influência mútua entre processos mentais e físicos e ressalta o papel patogênico das emoções. Estes quadros não eram acompanhados de febre ou dispnéia, mas caracterizava-se pela diminuição do apetite, amenorréia, aversão à comida, obstipação, emagrecimento extremo e hiperatividade. $\mathrm{O}$ autor se mostra intrigado pela indiferença característica que essas pacientes denotam em relação a seu estado de desnutrição e pela preservação de suas faculdades mentais básicas (SILVERMAN $\left.{ }^{147}, 1993\right)$.

$\mathrm{Na}$ segunda metade do século XIX, a anorexia nervosa emerge como uma entidade clínica independente, com sintomatologia e patogenia distintas, a partir dos relatos do francês LASÉGUE" ${ }^{90}$ 1873, que descreve a "anorexie histérique". Em 1874, GULL ${ }^{72}$, descreve três meninas com quadro anoréxico como o nome de "apepsia histérica" (VAN DER HAM et al. $\left.{ }^{165}, 1997\right)$.

No começo do século $X X$, a anorexia nervosa começa a ser tratada sobre um ponto de vista endocrinológico, assim em 1914 Simonds um patologista alemão, descreveu uma paciente caquética, a quem, ao fazer-lhe autopsia encontrou uma destruição da glândula pituitária e durante os 30 anos seguintes, reinou a confusão entre insuficiência pituitária (doença de Simonds) e anorexia nervosa. A partir dos anos 30 a anorexia nervosa passa a ser estudada principalmente sobre o ponto de vista psicológico, deixando no esquecimento as antigas discussões sobre a origem endocrinológica ou psicológica do transtorno (BEAUMONT $\left.{ }^{29}, 1991\right)$.

$\mathrm{Na}$ década de 1970, começam a surgir critérios padronizados para o diagnóstico da anorexia nervosa com base nos distúrbios psicobiológicos e psicopatológicos, desenvolvidos para atender tanto as necessidades clínicas como as de pesquisa (RUSSELL ${ }^{136}, 1970$ ). De modo geral, os critérios ressaltaram: a perda considerável de peso, a preocupação mórbida com o risco de engordar, 
alterações na percepção corporal e disfunções endócrinas (ex: amenorréia), aspectos concebidos como diagnósticos de anorexia nervosa pelos atuais sistemas classificatórios $\left(\mathrm{OMS}^{124}, 1993 ; \mathrm{APA}^{9}, 1994\right.$; CORDÁS $\left.{ }^{50}, 2004\right)$.

\subsubsection{Critérios diagnósticos}

Diversos critérios operacionais foram propostos para AN a maioria deles englobando basicamente: comportamentos visando à perda de peso e sua manutenção abaixo do normal; medo de engordar; distúrbio de imagem corporal e distúrbio endócrino como a amenorréia (RUSSEL $\left.{ }^{136}, 1970\right)$. Os critérios diagnósticos para a AN segundo os sistemas de classificação DSM-IV (Diagnostic and Statistical Manual, IV edition) $\left(\right.$ APA $^{9}$, 1994) e CID-10 (Classificação Internacional de Doenças, 10ª edição), (OMS ${ }^{124}$, 1993) são descritos na Figura 1.

A perda de peso auto-induzida é necessária para o diagnóstico, porém a linha que separa o que seria "minimamente normal" e "abaixo do peso" não é tão clara. Para padronização tem-se utilizado o Índice de Massa Corpórea (IMC = peso/altura ${ }^{2}$ ) $<17,5$ (critério utilizado pela CID-10) ou percentual de adequação de peso inferior a 85\% (critério utilizado pelo DSM IV), considerando-se também a situação de pacientes em crescimento que apresentariam falhas em alcançar o ganho de peso esperado para o período (CLAUDINO; BORGES $\left.{ }^{48}, 2002\right)$.

O medo intenso ou mórbido de engordar representa o aspecto psicopatológico central da $\mathrm{AN}$, sendo concebidos como o critério que distinguiria esta de outras síndromes psiquiátricas. Porém existe uma dificuldade de se avaliar tal aspecto em algumas pacientes, que podem esconder o medo de engordar ou mesmo expressar verbalmente o desejo de ganhar peso, e exibir a fobia pelo seu comportamento e não pela palavra (GARFINKEL $\left.{ }^{66}, 1995\right)$.

O distúrbio de percepção corporal tem sido alvo de discussão entre os pesquisadores. Esse conceito tem demonstrado sua complexidade por não se ater apenas a avaliações neuroperceptivas do esquema corporal, mas envolver também dimensões afetivas (sentimentos em relação à imagem corporal) e comportamentais (atitudes), dentre outros aspectos. Sabe-se que tais distúrbios não são 
patognomônicos da AN, ocorrendo também em outras patologias e em indivíduos normais. Por estas razões o DSM-IV incorporou nesse critério alguns aspectos psicodinâmicos como: a negação da gravidade da perda de peso (negação dos riscos) e a auto-avaliação excessivamente centrada no peso e forma (LINDHOLM; WILSON $\left.^{94}, 1988\right)$.

$\mathrm{Na}$ AN existe a chamada perturbação no modo de vivenciar o próprio peso e imagem corporal, ou seja, a dificuldade de perceber o próprio corpo como ele é na realidade. Para que a pessoa se conscientiza, não bastam sequer os problemas de saúde provocados pela magreza excessiva (CAMPOS $\left.{ }^{43}, 2002\right)$.

A AN envolve também uma disfunção endócrina, especialmente do eixo hipotalâmico-hipofisário-gonadal, identificada pela amenorréia em mulheres e perda do interesse e potência sexual nos homens. Em pré-púberes, há retardo do desenvolvimento das características sexuais secundárias (CLAUDINO; BORGES ${ }^{49}$, 2002). Contudo, a amenorréia permanece como um critério controverso, em risco de exclusão, pois parece contribuir pouco para a definição de caso devido a alguns fatores: a) até 30\% das pacientes podem apresentar todo o quadro característico de anorexia sem amenorréia; b) $20 \%$ a $30 \%$ das pacientes apresentam amenorréia antes de haver perda importante de peso; c) dificuldades em se colher história menstrual confiável e; d) inexistência de um critério paralelo para homens. A manutenção do critério tem se justificado com base no fato de alertar para o distúrbio endócrino subjacente e suas seqüelas (osteoporose) (GARFINKEL $\left.{ }^{66}, 1995\right)$.

Estudos epidemiológicos demonstram que há dificuldades relacionadas ao diagnóstico correto dos transtornos alimentares, como por exemplo, a recusa do paciente em procurar ajuda profissional ou por não admitir que esteja doente ou achar que conseguirá se tratar sozinho. Com isso somente os casos mais graves procuram tratamento, o que pode implicar em incidência e prevalência subestimadas (FAIRBURN; HARRISON ${ }^{61}, 2003$ ). 
1.Perda de peso e manutenção do mesmo abaixo de $85 \%$ do esperado para a altura e idade;

2.Medo intenso de ganho de peso ou de ser tornar gordo, mesmo com peso inferior;

3.Perturbação no modo de vivenciar o peso, tamnaho ou forma corporais, excessiva influência do peso ou forma corporais na autoavaliação, negação do baixo peso;

4.Ausência de pelo menos três ciclos menstruais consecutivos.
1.Perda de peso ou, em crianças, falta de ganho de peso. Peso corporal se mantém no mínimo, 15\% abaixo do esperado;

2.A peda de peso é auto-induzida pela evitação de "alimentos engordativos";

3.Distorção na imagem corporal com medo excessivo de engordar;

4.Transtorno endócrino generalizado envolvendo o eixo hipotalâmicohipofisáriogonodal, manisfestado em mulheres como amenorréia, em homens como uma perda de interesse e potência sexuais e atraso do desenvolvimento puberal;

\section{DSM-IV}

Restritivo: ausência de episódios compulsivos e/ou comportamentos purgativos;

Purgativo: presença de episódios compulsivos e/ou comportamentos purgativos.

Figura 1 - Critérios diagnósticos para a anorexia nervosa segundo os sistemas de classificação

DSM - IV e CID - 10

Existem dois tipos de apresentação da AN: o tipo restritivo e o tipo purgativo. Os seguintes tipos podem ser usados para a especificação da presença ou ausência de compulsões periódicas ou purgações regulares durante o episódio atual de AN. No primeiro, os pacientes utilizam comportamentos restritivos associados à dieta. Na AN tipo purgativo acontece episódios de compulsão alimentar, seguido de métodos compensatórios, como vômitos auto-induzidos e o uso de laxantes e diuréticos (BORGES et al. $\left.{ }^{34}, 2006\right)$. 


\section{Tipo Restritivo}

Pacientes com AN do tipo restritivo a perda de peso é conseguida principalmente através de dietas, jejuns ou exercícios excessivos. Durante o episódio atual, esses pacientes não desenvolveram compulsões periódicas ou purgações, como, auto-indução de vômito ou uso indevido de laxantes, diuréticos ou outros.

\section{Tipo Purgativo}

Ocorre quando o paciente se envolve regularmente em compulsões de comer seguidas de purgações durante o episódio atual de anorexia. A maioria dos pacientes com AN que comem compulsivamente também faz purgações mediante vômitos auto-induzidos ou uso indevido de laxantes, diuréticos ou enemas. Alguns pacientes incluídos neste tipo não comem de forma compulsiva, mas fazem purgações regularmente mesmo após o consumo de pequenas quantidades de alimentos. Aparentemente, a maior parte dos pacientes com o AN tipo purgativo dedica-se a essa prática pelo menos uma vez por semana (APA $\left.{ }^{9}, 1994\right)$.

Os pacientes com AN do tipo Restritivo são menos graves e têm melhor prognóstico quando comparados com o tipo purgativo. Estes estão mais propensos a ter outros problemas de controle dos impulsos, a abusarem de álcool ou outras drogas, a exibirem maior instabilidade do humor e a serem sexualmente ativos (FAIRBUN; HARRISON ${ }^{61}, 2003$ ).

\subsubsection{Aspectos clínicos e complicações sistêmicas}

O início do quadro clínico ocorre freqüentemente a partir da elaboração de uma dieta, devido à insatisfação com a forma e o peso corporal. A refeição, quando é feita, demora excessivamente para se completar, o paciente opta por fazêlas solitariamente e evitam locais públicos onde este inicia a restrição de grupos 
alimentares, eliminando aqueles que julgam mais calóricos, como doces, massas, gorduras. Essa restrição alimentar aumenta progressivamente, passam a eliminar as carnes vermelhas e brancas. O número de refeições e quantidade de alimentos ingerida diminui progressivamente, chegando a dias de jejum absoluto. O paciente tem como meta emagrecer, cada vez mais, desejando a todo custo ficar cada vez mais magro (PHILIPPI; ALVARENGA ${ }^{129}$, 2004).

Um estranho comportamento, em relação à comida pode ser desenvolvido. Ocorre uma piora no estado nutricional e consultas a tabelas de calorias, freqüentemente. Apresentam pensamento constante sobre alimentação, colecionam receitas, preparam refeições para outras pessoas, escondem alimentos por toda casa, cortam e embalam alimentos em pequenos pedaços, organizam a comida no prato várias vezes. A avaliação distorcida da imagem corporal e a repulsa sistemática ao consumo de alimentos são as características mais comuns desse transtorno. Há pessoas em estágios avançados de desnutrição, pesando até 30 quilos e com uma aparência cadavérica insistindo em se descreverem como obesas (CORDÁS; BUSSE ${ }^{51}$, 1995; LOUZÃ NETO et al. ${ }^{96}$, 1995).

Na AN é possível se observar depressão, irritabilidade e comportamentos peculiares como rituais compulsivos, estranhos hábitos alimentares como divisão da comida em categorias saudáveis e perigosos. A pessoa tem uma baixa capacidade de enfrentar mudanças e situações novas, temem crescer, assumir responsabilidades da vida adulta, por isso são sempre dependentes dos pais. A dieta pode representar a dificuldade em lidar com um estágio como a adolescência. A debilitação física favorece a presença de outros sintomas, como dificuldade de concentração, irritabilidade, mau humor, depressão, ansiedade, perfeccionismo. O comportamento sexual é deficiente, a aparência do individuo assexuada, talvez como forma de se proteger da sexualidade (EMANS ${ }^{58}, 2000 ;$ KAUFMAN $\left.^{86}, 2000\right)$.

Os portadores de AN nem sempre são inapetentes, apenas negam ou controlam a fome criando estratégias e rituais obsessivos relacionados à comida. Para enganar médicos e familiares, provocam brigas durante as refeições para se levantarem da mesa sem comer. Durante as internações em hospitais, fornecem a sua refeição para outros pacientes, tomam moderadores de apetite sem 0 conhecimento médico e até colocam pesos dentro de suas roupas para parecerem 
mais gordas no momento de se pesarem com a finalidade de receber alta (EMANS $\left.{ }^{58}, 2000\right)$.

Geralmente os pacientes relatam que o início do quadro se deu após um fator estressante como algum comentário sobre seu peso, ou o término de relacionamento, ou perda de ente querido. Paulatinamente o paciente passa a viver exclusivamente em função da dieta, do peso, da forma corporal, das atividades físicas, de tabela de calorias e do medo patológico de engordar. Concomitantemente esses pacientes apresentam traços de personalidade como preocupações e cautela em excesso, medo de mudanças, hipersensibilidade e gosto pela ordem (CERESER; CORDÁS $\left.^{47}, 2001\right)$.

Exercícios físicos extenuantes são comuns e cessam somente quando há uma impossibilidade concreta. Alguns se limitam a restringir, apresentando características obsessivas e compulsivas; outros lançam mão de uso de laxantes, diuréticos, anorexígenos e vômitos para compensarem episódio de compulsão alimentar, ou mesmo na ausência de compulsão, apenas para controlar o peso, denotando comportamento impulsivo (KAPLAN; SADOCK; GREBB ${ }^{85}$, 1997; APA ${ }^{10}$, 2000).

Os achados clássicos no exame físico desses pacientes estão relacionados à desnutrição e à disfunção hipotalâmica, incluem pele seca, hipotermia, bradicardia, hipotensão, bradipnéia e edema de membros. A gravidade da desnutrição pode ser avaliada pelo índice de massa corpórea (IMC), que é obtido pela divisão do peso pelo quadrado da altura (faixa de desnutrição inferior a 18 $\mathrm{kg} / \mathrm{m}^{2}$ para adultos) (EMANS $\left.{ }^{58}, 2000\right)$.

Alteração metabólica como hipercolesterolemia pode ser observada em pacientes com AN, porém sua causa não é completamente conhecida. Provavelmente, decorre da redução dos níveis de T3. Quarenta por cento dos pacientes com AN apresentam uma elevação do colesterol total (CT), à custa do LDL-colesterol. A hipoglicemia tanto pode ocorrer após jejuns prolongados, como em resposta a um ECA (episódio de compulsão alimentar) seguido de vômitos, sendo freqüentemente assintomática. Cerca de $56 \%$ dos pacientes anoréxicos tem glicemia menor que $70 \mathrm{mg} / \mathrm{dl}$ (NUNES et al. $\left.{ }^{119}, 2006\right)$. 
A amenorréia pode ser acompanhada de várias anormalidades: regressão dos ovários para estágios pré-puberais com múltiplos pequenos folículos, regressão do tamanho mamário e, às vezes, perda parcial dos pelos pubianos. A infertilidade pode ocorrer, porém ovulações ocasionais podem acontecer (ASSUMPÇÃO; CABRAL $\left.^{18}, 2002\right)$.

Quando a AN ocorre na fase precoce da puberdade, pode ocorrer atraso na maturação sexual, no desenvolvimento físico e no crescimento, e não atingem a estrutura esperada. A osteopenia ou até mesmo osteoporose irreversível também afetam esses pacientes, favorecendo a ocorrência de fraturas patológicas. A osteopenia também pode ocorrer no sexo masculino, em decorrência da diminuição da testosterona (PHILIPPI; ALVARENGA ${ }^{129}$, 2004)

Devido o emagrecimento, o organismo responde com amenorréia, desativação da glândula tireóide, diminuição da freqüência respiratória e da pressão arterial. Com o desequilíbrio hormonal, unhas e cabelos tornam-se quebradiços, a pele resseca e fica recoberta por uma pelugem. A redução da gordura corporal causa menor resistência ao frio e a deficiência de glicose, resultante da falta de nutrientes, provoca hipoglicemia, tonturas, desmaios, insuficiência cardíaca, como a morte cerebral. O estômago diminui de tamanho e perde a motilidade, fazendo com que o paciente se sinta satisfeito com pequenas quantidades de comida (CORDÁS; BUSSE $\left.^{51}, 1995\right)$.

Pele seca, pálida, coloração amarelada, cabelos finos e quebradiços, pilosidade na pele (lanugo) e leve alopecia conferem aos pacientes anoréxicos uma aparência bastante envelhecida, apesar de muito jovens. Dentre as características clínicas relacionadas à AN estão as alterações metabólicas, prolapso da valva mitral, metabolismo tireóideo reduzido, baixa temperatura corporal, bradicardia, edema, infertilidade, desidratação, arritmias e anemias. Pode haver também, interrupção do ciclo menstrual, constipação, dor abdominal, fadiga, dificuldade de concentração (MAHAN; STUMP ${ }^{104}$, 1998; EMANS ${ }^{58}$, 2000; KAUFMAN ${ }^{86}$, 2000; BUSSE; SILVA ${ }^{41}$, 2004). 


\subsubsection{Tratamento e prognóstico}

As estratégias sugeridas para o tratamento da AN objetivam a diminuição da restrição alimentar e da freqüência de atividade física, facilitando o aumento do peso; a diminuição do distúrbio da imagem corporal; a modificação do sistema disfuncional de crenças associadas à aparência; peso e alimentação; e o aumento da auto-estima. Restaurando o estado nutricional, evita-se que as complicações do emagrecimento, desidratação e desequilíbrio eletrolítico possam levar à morte (LOUZÃ NETO et al. ${ }^{96}$, 1995; ALMEIDA $^{5}$, 2001).

A normalização da alimentação inicia-se pela discussão dos fatores que favorecem a manutenção da restrição dietética e por orientações acerca de alimentação e regulação de peso. O tratamento concentra-se no estabelecimento de horários regulares para alimentação e na exposição gradual aos alimentos e situações freqüentemente evitadas (ALMEIDA $\left.{ }^{5}, 2001\right)$.

É de suma importância o reconhecimento da doença por parte do paciente, o que nem sempre é fácil, onde a colaboração do paciente é quase nula, portanto, para se atingir os melhores resultados, deve-se contar com o apoio familiar e uma equipe multidisciplinar. A maioria dos pacientes recebe tratamento ambulatorial, com retornos de curtos períodos, que consiste basicamente na associação de drogas antidepressivas aliada à terapia comportamental, que possibilita ao paciente lidar com as dificuldades internas que levaram ao surgimento dos sintomas (KAUFMAN $\left.{ }^{86}, 2000\right)$.

A internação hospitalar procede apenas nos casos mais delicados, onde a condição nutricional apresenta-se com peso corporal abaixo de $75 \%$ do mínimo ideal, quando estão perdendo peso rapidamente ou quando se faz necessária a monitorização adequada das suas condições clínicas (APPOLINÁRIO; CLAUDINO ${ }^{14}$, 2000).

As taxas de recuperação da anorexia nervosa após o tratamento são variáveis, podendo ir de um único episódio até evoluções crônicas e recaídas sucessivas. Estima-se, no entanto, que em torno de 30 a $40 \%$ dos pacientes tenham recuperação completa, não voltando a apresentar outros episódios da 
doença. Outros 30 a 40\% têm uma evolução mediana, oscilando entre períodos de melhora e de recidiva da doença, podendo evoluir para bulimia nervosa. O restante dos pacientes tem um curso grave, com complicações físicas e psicológicas mais sérias (BORGES et al. $\left.{ }^{34}, 2006\right)$.

O índice de mortalidade pode chegar a 20\%, em razão das complicações decorrentes da própria doença e suicídio. Alguns fatores são preditivos de uma evolução desfavorável, como peso muito baixo no início do tratamento, aparecimento tardio da doença, demora para procurar ajuda médica, presença de práticas purgativas, relações familiares comprometidas e comorbidade psiquiátrica (PHILIPPI; ALVARENGA ${ }^{129}$, 2004).

O sucesso do tratamento depende de vários fatores, entre eles o esforço da família para ajudar o doente a livrar-se do problema, este aspecto é ainda mais importante quando o paciente é jovem. Esse tem melhorado em função de uma maior sistematização e padronização de condutas terapêuticas baseadas em evidências (CAMPOS ${ }^{43}$, 2002; APPOLINÁRIO; CÓRDAS; CLAUDINO ${ }^{15}$, 2002).

\subsubsection{Bulimia nervosa}

\subsubsection{Definição}

O termo bulimia deriva do grego (bous = boi ou bou = grande quantidade de e limos = fome), designando "fome raivosa" ou "fome de comer um boi" assim um apetite tão grande que seria possível a um homem comer um boi, ou quase. Entre os séculos XV e XVIII, diferentes variantes do termo, como os derivados do latim "bulimus" e "bolismos" ou do francês "bolisme", com o mesmo significado anterior, foram empregados na literatura médica na Inglaterra, França, Alemanha e Polônia (PARRY-JONES; PARRY-JONES ${ }^{126}, 1991$ ).

A bulimia nervosa (BN) corresponde a um tipo de TA caracterizado por episódios recorrentes de hiperfagia, onde ocorre ingestão de alimentos de uma maneira muito rápida e com a sensação de perda de controle, com pouco ou 
nenhum prazer, os chamados episódios bulímicos. Estes são acompanhados de métodos compensatórios inadequados para prevenir o ganho de peso, como a regurgitação auto-induzida (em mais de 90\% dos casos), uso de abusivo de medicamentos (diuréticos, laxantes, inibidores de apetite), dietas (períodos de restrição alimentar severa) e exercícios físicos, abuso de cafeína ou uso de cocaína (FAIRBURN ${ }^{59}$, 1995). Tal comportamento, também se desenvolve devido ao medo mórbido de engordar (AZEVEDO; ABUCHAIM ${ }^{20}$, 1998). Alguns bulímicos chegam a consumir de 1000 a $5000 \mathrm{kcal}$ em menos de uma hora, geralmente alimentos calóricos e de fácil digestão, sem preocupar-se com o gosto ou textura desses alimentos, num ritual que podem durar horas e ocorre secretamente (BUSSE; SILVA $\left.^{41}, 2004\right)$.

\subsubsection{Histórico}

Em 1743, James descreve a true boulimus para os episódios de grande ingestão de alimentos e preocupação intensa com os mesmos, seguidos de desmaios e uma variante chamada caninus appetities, com vômitos após estes episódios (HABERMAS $\left.{ }^{73}, 1989\right)$.

Esse comportamento de forçar o vômito é muito antigo e pode ser encontrado precocemente na história de diferentes povos da antiguidade. No Egito, grande parte do papiro de Eber é dedicado ao estímulo e às virtudes do ato de vomitar. Segundo Heródoto, os egípcios vomitavam e usavam purgativos todo mês, por três dias consecutivos, julgando que as doenças dos homens são oriundas da comida. Na medicina grega é sabido que Hipócrates também recomendava a indução de vômitos por dois dias consecutivos todo mês como um método de prevenir diferentes doenças. Os romanos criaram o vomitorium, que Ihes permitia alimentar-se em excesso durante os banquetes, e posteriormente vomitar em local reservado para esta finalidade, às vezes usando uma pena de ave para estimular o reflexo do vômito na garganta (CASPER $\left.{ }^{45}, 1983\right)$.

A descrição de BN, tal como a conhecemos hoje, foi elaborada por Russell em 1979, em Londres, quando descreveu trinta pacientes com peso normal, 
pavor de engordar, episódios bulímicos e vômitos auto-induzidos. Como essas pacientes haviam apresentado anorexia nervosa no passado, Russel considerou inicialmente que a bulimia seria uma seqüela, uma "estranha" variação da anorexia nervosa (RUSSELL ${ }^{136}, 1979$ ).

Segundo CÓRDAS; CLAUDINO ${ }^{52}$, 2002, desde a primeira descrição da BN por Gerald Russell em 1979, o conhecimento deste quadro como entidade nosológica distinta tem avançado rapidamente, graças à proliferação de grupos de pesquisa em vários países. Este fato é, principalmente, reflexo da importância clínica e epidemiológica que a BN vem demonstrando, superando em número de publicações, o interesse pela sua "irmã mais velha", a AN.

Diferentes nomes já foram dados ao quadro, incluindo hiperorexia nervosa, bulimarexia, bulivomia, síndrome do caos alimentar, bulimia e, finalmente, BN, termo hoje, de aceitação geral (RUSSEL ${ }^{136}$, 1979; BOSKIND-WHITE; WHITEJR $^{35}$, 1985; FAIRBURN ${ }^{59}$, 1995; FICHTER $\left.{ }^{63}, 1990\right)$.

\subsubsection{Critérios diagnósticos}

A BN só começou a ter um diagnóstico independente em 1980, na $3^{a}$ edição do Manual Diagnóstico e Estatístico dos Transtornos Mentais (DSM-II) da Associação Psiquiátrica Americana (APA). Na 10 ${ }^{\mathrm{a}}$ edição da Classificação de Transtornos Mentais e de Comportamento (CID-10) da Organização Mundial de Saúde (OMS), a anorexia e bulimia nervosas são classificadas independentemente. A classificação do DSM-IV distingue dois tipos de pacientes com BN conforme a utilização de métodos compensatórios mais invasivos (vômitos, laxantes, diuréticos, outras drogas), tipo purgativo ou não (dietas, jejuns e exercícios), classificado no tipo não purgativo (LOUZÃ NETO et al. ${ }^{96}$, 1995). Os critérios diagnósticos estão dispostos na Figura 2.

Existe um consenso na literatura quanto à necessidade da presença da "compulsão alimentar" para o diagnóstico de BN, mas não quanto à sua definição e freqüência. O DSM-IV descreve a compulsão com base em dois aspectos: 1) ingestão, em um período limitado de tempo (por ex., dentro de um período de duas 
horas) de uma quantidade de alimentos definitivamente maior do que a maioria das pessoas consumiria durante um período similar e sob circunstâncias similares e; 2) um sentimento de falta de controle sobre o comportamento alimentar durante o episódio (por ex., um sentimento de incapacidade de parar de comer ou de controlar que ou o quanto está comendo) (CLAUDINO; BORGES $\left.{ }^{48}, 2002\right)$.

O diagnóstico da BN exige o engajamento em métodos compensatórios inadequados seguindo-se os episódios bulímicos. O vômito auto-induzido é o método mais freqüente, de mais fácil identificação e que melhor delimita o final de uma compulsão. O reconhecimento de que algumas pacientes buscam compensar a compulsão por meio de métodos não purgativos apenas (jejuns e exercícios excessivos), aliado a indícios de maior psicopatologia alimentar e geral em purgadoras (depressão, ansiedade, abuso de substâncias e sexual) levou à distinção de grupos de bulimia pelo DSM-IV (HAY; FAIRBURN $\left.{ }^{76}, 1998\right)$.

O episódio bulímico refere-se à ingestão de uma quantidade exagerada de alimentos, corresponde ao aspecto central do diagnóstico da BN. Em pacientes com transtornos alimentares, a bulimia não visa apenas saciar uma fome exagerada, mas atende a uma série de estados emocionais ou situações estressantes. A literatura inglesa utiliza o termo binge-eating para descrever este comportamento, traduzido para o português como compulsão alimentar periódica (HAY ${ }^{75}$, 2002).

Em pacientes com TAs, a BN não visa apenas saciar uma fome exagerada, mas atende a uma série de estados emocionais ou situações estressantes. Essas condutas são destinadas a diminuir a agonia resultante de um acesso bulímico, e servem como forma de controle de peso. No final do acesso bulímico, a pessoa experimenta um intenso sentimento de culpa e necessidade de autopunição (KAUFMAN ${ }^{86}, 2000$; CLAUDINO; BORGES ${ }^{48}, 2002$ ). 
1. Episódios recorrentes de compulsão alimentar (episódios bulímicos): ingestão de quantidade de comida maior do que a maioria das pessoas comeria, em curto intervalo de tempo (por exemplo, em duas horas), sensação de perda de controle sobre o que e quanto se come;

2. Comportamentos compensatórios inapropriados para prevenir ganho de peso, como vômito auto induzido, laxantes, diuréticos ou outras drogas, dieta restritiva ou jejum ou, ainda, exercícios físicos excessivos;

3. Os episódios bulímicos e os comportamentos compensatórios ocorrem, em média, duas vezes por semana, por pelo menos três meses;

4. A auto-avaliação é indevidamente influenciada pelo peso e formas corporais.
1. Episódios de hiperfagia, nos quais grandes quantidades de alimento são consumidas em curtos períodos de tempo (pelo menos duas vezes por semana durante um período de três meses);

2. Preocupação persistente com o comer e um forte desejo ou um sentimento de compulsão a comer;
3. Utilização de neutralizadores dos efeitos "de engordar": vômitos auto-induzidos, laxantes, jejuns, drogas como anorexígenos, preparados tireoidianos ou diuréticos;

4. Autopercepção de estar muito gordo, com medo intenso de engordar e prática de exercícios excessivos ou jejuns.

Figura 2 - Critérios diagnósticos para a bulimia nervosa segundo os sistemas de classificação DSM - IV e CID - 10

\subsubsection{Aspectos clínicos e complicações sistêmicas}

O indivíduo que desenvolve o quadro de $\mathrm{BN}$, em geral, valoriza muito a forma do corpo e o peso, possuindo uma percepção física distorcida e dificuldade em identificar as emoções. Apresenta baixa auto-estima, nível elevado de ansiedade, baixo limiar à frustração e prejuízo no controle dos impulsos. Em sua insegurança, elege padrões de beleza muito altos, praticamente inatingíveis, na tentativa de corresponder à tendência da sociedade em eleger a magreza como símbolo de sucesso e beleza. Ao perceber que não atingiu suas metas, sente-se deprimida, fracassada e retorna à compulsão, com conseqüente culpa e depressão $\left(\mathrm{BEHAR}^{30}, 1994\right)$. 
As características principais da BN são: episódios de hiperfagia, em que há uma ingestão de grande quantidade de alimento consumido em um período de tempo; sensação de perda de controle sobre a ingestão dos alimentos; condutas compensatórias inadequadas para evitar o ganho de peso; os episódios devem ocorrer pelo menos duas vezes por semana durante três meses; a auto-estima é exageradamente influenciada pelo peso corporal (POP-JORDANOVA ${ }^{132}, 2000$ ).

A BN é um transtorno alimentar caracterizado por episódios periódicos de compulsão alimentar, seguido de comportamentos compensatórios inadequados, com o objetivo de evitar o ganho de peso. A indução de vômitos (80\% a 90\% dos casos) e o uso de laxantes e diuréticos (50\% dos casos) são práticas compensatórias da $\mathrm{BN}$ do tipo purgativo e a prática de jejuns ou atividade física excessivos são característicos do tipo não purgativo. A percepção da forma e do peso corporal é bastante alterada e característica essencial da BN. Esses pacientes apresentam uma falta de autocontrole e, às vezes podendo estar associado à obesidade $\left(\right.$ APA $^{10}, 2000$; CAMPOS $^{43}$, 2002; CLAUDINO; BORGES $\left.{ }^{48}, 2002\right)$.

No perfil psicológico de um paciente bulímico é possível observar depressão, perfeccionismo, baixa auto-estima, ansiedade, dúvidas pessoais, raivas e obsessão pelo sucesso. Também apresenta pouco autocontrole, o que pode leválos a aventuras sexuais, uso e abuso de drogas e álcool e outros comportamentos de risco porque não consideram as conseqüências. No entanto, estas pessoas se mostram extrovertidas, inteligentes e equilibradas emocionalmente somente na frente de outras pessoas (DE CONTE; MORENO ${ }^{54}$, 1995; LEITE; PINTO ${ }^{92}$, 2001).

Os episódios bulímicos e comportamentos compensatórios ocorrem em média duas vezes por semana, durante pelo menos três meses e ocorre uma autoavaliação indevidamente influenciada pela forma e pesos corporais. A primeira característica clínica é dada pela descrição de que o paciente ingere compulsivamente, grande quantidade de alimento em um curto espaço de tempo, ou às vezes em longo ritual de várias horas ou uma noite inteira. A pessoa ingere uma quantidade de até 10 mil calorias de uma vez, quando a necessidade para um ser humano adulto sobreviver é de 2,5 mil calorias diárias. Os alimentos escolhidos pelos bulímicos para ingestão nas crises compulsivas, geralmente são de fácil acesso, muitas vezes ricos em carboidratos e evitados em dietas hipocalóricas, 
como doces, chocolates, biscoitos, leite condensado (TEIXEIRA; NETO ${ }^{161}, 2003$ ). Além disso, deve haver um sentimento de perda de controle sobre a alimentação, ou seja, um sentimento de não poder parar de comer ou não controlar o que e quanto se come. Após a ingestão dos alimentos, o vômito é forçado com os dedos ou com uma leve pressão sobre o estômago. Assim, torna-se possível manter o peso dentro da normalidade. Algumas vezes depois de vomitar a pessoa volta a comer imediatamente, permanecendo, no final, com um sentimento de culpa, vergonha e desejo de autopunição. Normalmente, tais episódios ocorrem às escondidas, não dá atenção ao sabor e a textura do alimento, comendo sem nenhum critério na hora da compulsão (CORDÁS; BUSSE ${ }^{51}$, 1995; TRAEBERT; MOREIRA ${ }^{163}$, 2001; CORDÁS $\left.^{50}, 2004\right)$.

O xarope de Ipeca, que é feito das raízes da planta Ipecacuanha, para uso da indústria farmacêutica, é um irritante violento que estimula o sistema gástrico e bronquial, abaixa febre e previne a formação de cisto em disenteria motivada por ameba e também é usado para induzir o vômito em caso de intoxicação. Essa prática quando realizada em excesso, causa vômito severo e diarréia. Apenas, deve ser usado por médicos qualificados, porém é utilizado freqüentemente por pacientes com anorexia e bulimia nervosa para induzir o vômito (MAHAN; ESCOTT-STUMP ${ }^{103}$, 2002).

Pacientes com BN apresentam distúrbios eletrolíticos, alterações do funcionamento cardíaco; sangramento gástrico e esofágico, lesões intestinais pelo uso prolongado e inadequado de laxantes; lesões renais pelo uso de diuréticos; desgaste dentário, aumento das parótidas, lesões no estômago e esôfago devido aos vômitos. Bradicardia de repouso, hipotensão e diminuição da taca metabólica são observadas em alguns bulímicos, podendo refletir na diminuição da atividade do sistema nervoso simpático e do eixo tireoideano (APPOLINÁRIO; CLAUDINO ${ }^{14}$, 2000; LEITE; PINTO ${ }^{92}$, 2001)

O ato de vomitar quando freqüente pode provocar insuficiência cardíaca, devido à perda de minerais essenciais, como o potássio. Uma das complicações mais freqüentes e de maior risco para o desenvolvimento de arritmias cardíacas é a hipocalemia, causada pelo vômito, desnutrição e abuso de medicamentos depletores de potássio (diuréticos e laxantes). Os sintomas incluem fraqueza, confusão, 
náusea, palpitações, arritmia, poliúria, dor abdominal e constipação Nos casos mais graves, pode haver uma ruptura das paredes do estômago causada pelo excesso de alimentos (CORDÁS; BUSSE ${ }^{51}$, 1995).

Em decorrência da deficiência de ingestão de ferro ou de sangramento retal por uso excessivo de laxativos, pode ocorrer anemia do tipo ferropriva. Uma hipoplasia da medula pode ocorrer em pacientes bulímicos, que é secundária ao uso de laxativos contendo fenolftaleína (tóxicos para a medula) (CORDÁS ${ }^{50}, 2004$; BUSSE $^{40}$, 2004).

Úlceras ou escarificações dorsais da superfície das mãos e a presença de calos nos dedos podem ser observados em decorrência dos vômitos excessivos e foram descritos em 1979, por Russel. O nome "Sinal de Russel" foi dado a estas lesões que ocorrem como resultado de um trauma na pele, secundário ao uso das mãos como instrumento indutor dos vômitos. As lesões podem aparecer em qualquer lugar do dorso das mãos muito embora se situem mais usualmente na junção metacarpo-falangeana. Podem ser superficiais ou progredirem para calosidade hiperpigmentada com escarificações (CORDÁS ${ }^{50}$, 2004).

A constipação está entre as manifestações mais freqüentes da BN e decorre do uso de laxantes que, se utilizados em longo prazo, podem levar a danos irreversíveis ao cólon intestinal (cólon catártico). Nos pacientes com características purgativas pode se observar eritema do palato, faringe e gengiva e alterações dentárias como erosão do esmalte dentário que fica com aspecto liso e opaco. Os dentes mais acometidos são os incisivos e caninos; as cúspides dentárias podem se apagar reduzindo a altura do dente e há também um aumento da incidência de cáries (LEITE; PINTO ${ }^{92}$, 2001).

Observa-se também um aumento das glândulas parótidas. Os alimentos com alto teor de carboidratos podem causar intensa estimulação das glândulas, resultando em uma hipertrofia. A regurgitação contendo acido gástrico, a alcalose metabólica, a desnutrição e, o aumento do estimulo autonômico secundário a estimulação dos receptores linguais gustativos aumentam a liberação de enzimas proteolíticas pancreáticas contribuindo também para a parotidite. A freqüência e a gravidade da hipertrofia se correlacionam com a freqüência dos vômitos e ocorre 
entre $10 \%$ e 50\% das pacientes com BN. Geralmente o comprometimento é bilateral e indolor, mas raramente acomete as glândulas submandibulares. A hiperamilasemia acompanha a hipertrofia glandular salivar, desaparecendo com a descontinuidade dos vômitos (LASATER; MEHLER $\left.{ }^{89}, 2001\right)$.

Os vômitos freqüentes também podem levar à esofagite e ao sangramento da mucosa intestinal. A pancreatite aguda é uma rara complicação na BN, podendo ser secundária aos ECA ou ao uso abusivo de diuréticos. A hipoglicemia tanto pode ocorrer após jejuns prolongados, como em resposta a um ECA seguido de vômitos, sendo freqüentemente assintomática (ASSUMPÇÃO; CABRAL $^{18}$, 2002).

\subsubsection{Tratamento e prognóstico}

A BN parece ter evolução mais favorável que a AN, embora as pesquisas com BN ainda tenham pouco tempo de seguimento. Os trabalhos indicam índices de recuperação total entre 50\% e 70\%, conforme seus períodos de acompanhamento após manejo terapêutico (FAIRBURN et al. $\left.{ }^{60}, 2000\right)$.

Como na $\mathrm{AN}$, o tratamento da BN deve ser conduzido por uma equipe multiprofissional. A necessidade de internação hospitalar nos casos de BN está relacionada com a presença de complicações médico-psiquiátricas, de ciclos incoercíveis de compulsão alimentar-vômitos, de abuso de laxativos e/ou outras drogas e de outros comportamentos de risco. Na maioria das vezes, entretanto, o tratamento da BN é extra-hospitalar, devendo-se tentar um período inicial de abordagens como a psicoterapia cognitivo comportamental, o aconselhamento nutricional e o uso de psicofármacos, o que pode conduzir a uma melhora das pacientes (APPOLINÁRIO; CLAUDINO ${ }^{14}, 2000$ ).

Os estudos utilizando a fluoxetina no controle dos episódios de compulsão alimentar têm gerado um grande entusiasmo em relação à eficácia destes agentes no tratamento da BN, muito embora pareça improvável que todos os pacientes possam permanecer totalmente livres dos episódios de compulsão 
alimentar. A fluoxetina parece indicada em doses mais altas na BN (60 mg por dia em adultos) (APPOLINÁRIO et al. ${ }^{17}$, 2002).

A BN apresenta como fatores de bom prognóstico: sintomatologia leve a moderada, indicação de tratamento ambulatorial, duração menor da doença antes do tratamento, idade menor de início da doença, motivação para o atendimento e boa rede social de suporte. Indicam pior evolução da doença: sintomatologia mais severa, freqüência aumentada de vômitos no início do quadro, flutuações extremas de peso, impulsividade, baixa auto-estima, conduta suicida e transtornos comórbidos, como o uso de substâncias no início da patologia (BORGES et al. ${ }^{36}$, 2006).

Apesar da complexidade que envolve a patologia e seu diagnóstico, exigindo muitas vezes esforços multidisciplinares para compreendê-los, este transtorno tem cura. De cada 10 pacientes, 3 apresentam recuperação total e 3, melhora parcial. Os bulímicos até reconhecem a compulsão, mas tem vergonha do seu comportamento e só pedem ajuda quando a situação se torna insuportável. A recuperação é lenta e nem sempre definitiva. A reincidência diante de um acontecimento traumatizante é alta. Por isso, o constante acompanhamento psicoterápico é fundamental (KAUFMAN $\left.{ }^{86}, 2000\right)$.

\subsubsection{Transtorno de compulsão alimentar periódica}

\subsubsection{Definição}

O Transtorno de Compulsão Alimentar Periódica (TCAP) é uma atitude alimentar caracterizada pela ocorrência de episódios de comer grandes quantidades de comida de forma incontrolável até o ponto de sentir-se "cheio", em intervalos curtos de tempo, sensação de perda de controle sobre o ato de comer e, em seguida, arrependimento de ter comido. Estes episódios de compulsão são chamados de binge. Poderíamos traduzir binge como "ataques" de compulsão alimentar. Estes episódios ocorrem tanto na BN, quanto no TCAP. Neste transtorno, não existe purgação envolvida, isto significa que não é feita por parte da pessoa 
qualquer tentativa para se "livrar" do alimento ingerido, como vômitos, uso de laxantes e/ou diuréticos, e/ou exercícios físicos exagerados. Porem pode ocorrer episódios esporádicos de restrição alimentar e tentativas repetitivas de se submeter a dietas de emagrecimento, já que a maioria daqueles que sofrem de TCAP encontram-se acima do peso. Esses pacientes fazem parte do grupo de risco para ganho de peso e, à medida que o quadro evolui, atingem patamares de sobrepeso ou de obesidade. Esses episódios de hiperfagia são referidos na literatura internacional com o nome de Binge Eating (GRILO ${ }^{70}$, 2002; SALZANO; CORDÁS ${ }^{139}$, 2004).

\subsubsection{Histórico}

Durante muito tempo, indivíduos obesos foram considerados como pertencentes a um grupo homogêneo baseado apenas em uma característica comum - 0 peso. Ignoravam-se desta forma as possíveis diferenças comportamentais, que podem, em alguns casos, ter sido as desencadeadoras da obesidade (FRIEDMAN; BROWNELL $\left.{ }^{67}, 1995\right)$.

Obesos comedores compulsivos podem constituir uma subcategoria entre a população obesa, apresentando níveis mais elevados de psicopatologia, especialmente a depressão e transtorno de personalidade, uma gravidade maior e início mais precoce da obesidade, um percentual maior de sua vida gasto com dietas e prejuízo no funcionamento social e ocupacional (NAPOLITANO; HEAD; BABUAK $\left.^{117}, 2001\right)$.

A compulsão alimentar, enquanto comportamento, observada entre obesos foi descrita pela primeira vez por STUNKARD ${ }^{157}$, em 1959, no sentido de uma ingestão de enormes quantidades de comida em um curto espaço de tempo, seguida por sentimentos de desconforto físico e de autocondenação. A partir da década de 70, começou-se a pensar na compulsão alimentar como uma síndrome, surgindo relatos de indivíduos que apresentava uma associação com comportamentos compensatórios para prevenção de ganho de peso. (VANDEREYCKEN $\left.{ }^{166}, 1994\right)$. 
Em 1977, WERMUTH et al. ${ }^{169}$, ampliam a descrição realizada em 1959 por Stunkard e desenvolvem critérios diagnósticos para a síndrome da compulsão alimentar periódica: 1) ingestão rápida, impulsiva, episódica e sem controle de grandes quantidades de alimentos em um período de tempo relativamente curto; 2) o episódio termina apenas quando há desconforto físico (por exemplo, dor abdominal), vômitos auto-induzidos podem ocorrer, mas não são necessários para o diagnóstico; 3) sentimentos subseqüentes de culpa, desprezo por si ou remorso.

Diversos grupos ligados ao desenvolvimento do DSM-IV trabalharam em conjunto na criação de critérios para uma nova categoria dentre os transtornos alimentares, o TCAP. Essa proposta baseou-se na observação de que dentre os indivíduos obesos que procuravam tratamento em programas universitários envolvendo transtornos alimentares, uma grande parcela não era atendida por não preencher critérios diagnósticos para anorexia nervosa ou bulimia nervosa. Muitos obesos apresentavam a compulsão alimentar, mas não os comportamentos compensatórios inadequados para prevenção de ganho de peso, conforme critério requerido para bulimia nervosa (DEVLIN $\left.{ }^{55}, 1996\right)$.

Contudo, sua elevação à categoria diagnóstica apenas ocorreu em 1994, quando foi incluído no apêndice B do DSM IV (APA ${ }^{9}$, 1994), sob a forma de transtorno que necessita de maiores estudos para melhor caracterização. Assim, desde então, ocorreu um maior interesse em pesquisas nesta área, diferenciando um subgrupo de pacientes obesos com características alimentares específicas. Além disso, parece que os níveis de psicopatologia exibidos pelos pacientes com TCAP estão associados ao número de episódios de compulsão alimentar (HAY; FAIRBURN ${ }^{76}$, 1998).

\subsubsection{Critérios diagnósticos}

Os critérios propostos para o diagnóstico do TCAP requerem a presença de:

episódios recorrentes de compulsão alimentar periódica. Um ECA envolve algumas características principais: 1) ingestão, em um período limitado de tempo 
(por exemplo, dentro de um período de duas horas), de uma quantidade de alimento definitivamente maior do que a maioria das pessoas consumiria em um período similar, sob circunstâncias similares; 2) um sentimento de falta de controle sobre o episódio (por exemplo, um sentimento de não conseguir parar ou controlar o quê ou quanto se está comendo). Os ECA estão associados a três (ou mais) dos seguintes critérios: 1) comer muito mais rapidamente do que o normal; 2) comer até sentir-se incomodamente repleto; 3) comer grandes quantidades de alimentos, quando não fisicamente faminto; 4) comer sozinho, por embaraço pela quantidade de alimentos que consome; 5) sentir repulsa por si mesmo, depressão ou demasiada culpa após comer excessivamente (AZEVEDO; SANTOS; FONSECA ${ }^{21}$, 2004).

$>$ acentuada angústia relativa à compulsão alimentar.

$>$ ocorre, pelo menos dois dias por semana, durante seis meses. O método de determinação da freqüência difere daquele usado para a bulimia nervosa; futuras pesquisas devem dirigir-se à decisão quanto ao método preferencial para o estabelecimento de um limiar de freqüência, isto é, contar o número de dias nos quais ocorre a compulsão ou contar o número de ECA.

não está associada com o uso regular de comportamentos compensatórios inadequados (por exemplo, purgação, jejuns, exercícios excessivos), nem ocorre durante o curso de AN ou BN.

Um novo critério para o TCAP tem sido sugerido, a "auto-avaliação baseada no peso e na forma do corpo", já que este aspecto parece diferenciar obesos com e sem TCAP. Sendo esta uma característica central dos transtornos alimentares, este critério possibilitaria uma importante ligação do TCAP com a AN e a BN. Espera-se que mais estudos em andamento, analisando características psicobiológicas de indivíduos com TCAP e suas respostas a diversos tratamentos, fornecerão mais informações sobre a indicação de se estabelecer esta nova categoria diagnóstica (BORGES $\left.{ }^{33}, 1998\right)$. 
2.1.5.4 Aspectos clínicos e complicações sistêmicas

O comportamento alimentar no TCAP é caracterizado pela ingestão de grande quantidade de alimentos em um período de tempo delimitado (até duas horas), acompanhado da sensação de perda de controle sobre o quê ou o quanto se come $\left(\mathrm{APA}^{9}, 1994\right)$.

Os portadores de TCAP apresentaram baixos relatos de dietas restritivas quando comparados a pacientes com BN, que alternam entre compulsões e restrições alimentares. Os episódios compulsivos variavam quanto à hora em que costumam ocorrer com perda de controle, a hora sem esta perda e/ou perda de controle sem o consumo de uma grande quantidade de alimentos (GRILO ${ }^{70}, 2002$ ).

Os pacientes acometidos com TCAP apresentam "traços" de personalidade comuns: sintomas depressivos e ansiosos, baixa auto-estima; perfeccionismo; impulsividade; e pensamentos dicotômicos (do tipo "tudo ou nada", ou seja, total controle ou total descontrole). Alguns autores afirmam que um comedor compulsivo abrange no mínimo dois elementos: o subjetivo (a sensação de perda de controle) e o objetivo (a quantidade do consumo alimentar) (STUNKARD; ALLISON $^{158}$, 2003).

Há evidências de que pacientes com TCAP ingerem significativamente mais alimentos do que as pessoas obesas sem compulsão alimentar. O TCAP pode ocorrer em indivíduos com peso normal e indivíduos obesos. A maioria tem uma longa história de repetidas tentativas de fazer dietas e sentem-se desesperados acerca de sua dificuldade de controle da ingestão de alimentos. Alguns continuam tentando restringir o consumo de calorias, enquanto outros abandonam quaisquer esforços de fazer dieta, em razão de fracassos repetidos (GOLDFEIN et al. ${ }^{69}$, 1993; SPITZER et al. $\left.{ }^{155}, 1993\right)$.

O estresse é um fator que pode levar ao aumento das compulsões alimentares. Durante situações estressantes, o cortisol é liberado estimulando a ingestão de alimentos e o aumento do peso (STRIEGEL et al. ${ }^{156}$, 2001; STUNKARD; ALLISON $^{158}$, 2003). 
Estudo realizado por GELIEBTER ${ }^{67}$, 2002, demonstrou que pessoas obesas têm uma capacidade gástrica maior do que as pessoas com peso normal, o que poderia limitar a quantidade de alimentos ingeridos e de saciedade. Segundo o mesmo autor, desconhece-se a existência de um transtorno alimentar que tenha sido predisposto por uma grande capacidade gástrica.

O quadro é, em parte, muito semelhante à BN. A diferença é que no TCAP não há a necessidade de vomitar depois de comer bastante, como acontece na BN, onde também existem esses episódios de comer exageradamente (GRILO ${ }^{70}$, 2002).

O TCAP pode ser distinguido da BN, em alguns pontos. Os portadores de TCAP costumam apresentar índice de massa corporal (IMC) superior aos portadores de bulimia nervosa (GELIEBTER ${ }^{67}$, 2002). Além disso, a história natural da BN geralmente revela a ocorrência de dietas e perda de peso, enquanto que os comportamentos prévios do TCAP são mais variáveis (STRIEGEL et al. ${ }^{156}$, 2001). Assim, pacientes com BN mostram maiores níveis de restrição alimentar comparados aos portadores de TCAP (GRILO $\left.{ }^{70}, 2000\right)$.

\subsubsection{Tratamento e prognóstico}

Os pacientes com TCAP são grupo de risco para ganho de peso e, à medida que o quadro evolui, atingem patamares de sobrepeso ou de obesidade. Em um estudo populacional, FAIRBURN et al. ${ }^{60}, 2000$ observaram que a taxa de pacientes com TCAP que eram obesos aumentou de 22\% para 39\% após cinco anos de evolução.

Os objetivos do tratamento do TCAP devem incluir a redução dos episódios bulímicos, diminuição do peso corporal para pacientes obesos e melhora da psicopatologia associada (sintomas depressivos e ansiosos), preferencialmente com associação de psicofármacos e de psicoterapia (STUNKARD; ALLISON ${ }^{158}$, 2003). 
Tratar o quadro de depressão e ansiedade pode melhorar a compulsão por comida. Atividades físicas e terapêuticas como coadjuvantes do tratamento podem elevar a auto-estima dos doentes, facilitando a recuperação. As três classes de medicamentos que estão sendo estudadas no TCAP são: antidepressivos, inibidores de apetite com ação no sistema nervoso central e anticonvulsivante (AZEVEDO; SANTOS; FONSECA ${ }^{21}, 2004$ ).

\subsubsection{Características odontológicas}

\subsubsection{Complicações clínicas em saúde bucal}

Dentre as principais alterações bucais em paciente portador de TA destacam: descalcificação e erosão no esmalte dentário, cáries extensas, sensibilidade dentária a estímulos térmicos, alterações na mucosa bucal, problemas gengivais, edema de glândulas salivares, xerostomia, bruxismo, alterações ortodônticas, queilite e aumento da papila gengival (ROBB; SMITH ${ }^{133}, 1996$ ).

Os pacientes com TAs, devidos suas características psicológicas agravantes, acabam mostrando pouco ou nenhum interesse com os cuidados com relação à saúde bucal, as manifestações dentárias neste tipo de pacientes não levam a morte, porem são as únicas revertidas e para isso requer um tratamento preventivo e curativo adequado (ZÁRATE; RODRÍGUES ${ }^{172}$, 2000).

Os distúrbios psiquiátricos parecem ter influência definida na gravidade de doença periodontal que aumenta nos períodos de extrema ansiedade. É de suma importância à ingestão, absorção e utilização de várias vitaminas e minerais, pois estes são essenciais para manutenção de um periodonto normal (LOUZÃ NETO et al. $\left.{ }^{96}, 1995\right)$.

Em relação à perda de peso na AN a alcalose metabólica e a desnutrição promovem a formação de edemas de glândulas salivares parótidas e sublinguais. As deficiências vitamínicas levam ao aparecimento de queilites nos lábios e nas 
comissuras labiais. Os sintomas de AN podem ser acompanhados de bruxismo noturno, gengivites e aumento no índice de cáries (LEITE; PINTO ${ }^{92}$, 2001).

A dieta, rica em carboidratos e açúcares, consumida pelo pacientes favorece, ainda, a presença de cáries que são agravadas devido à xerostomia. A xerostomia pode ser acentuada pelo uso de medicamentos antidepressivos usados pelos pacientes portadores de ambas as doenças durante o tratamento. Muitos pacientes com esses distúrbios são dependentes químicos de drogas (álcool, fumo, medicamentos, etc), o que favorece a ocorrência de erosão dentária, xerostomia, formação do biofilme bacteriano e aumento de susceptibilidade à cárie (MAHAN; ESCOTT-STUMP ${ }^{103}$, 2002).

HAZELTON; FAINE ${ }^{77}$, em 1996, relataram que a atividade de cárie parece ser similar à da população em geral, entretanto em pacientes com lesões de cárie ativas a velocidade em que novas lesões se desenvolvem dificulta demasiadamente o tratamento. A região das papilas gengivais encontra-se aumentadas devido à irritação constante advinda do vômito ácido. A mucosa bucal também sofre os efeitos de tal comportamento. Importante notar que o periodonto e a mucosa bucal podem estar afetados devido à medicação que os pacientes possam estar utilizando, como os anticolinérgicos, cujo uso prolongado induz à xerostomia e aumento da papila gengival.

Ocorre um intumescimento das glândulas parótidas e, algumas vezes, das submandibulares de dois a seis dias após o episódio bulímico, se este for precedido de jejum. Este intumescimento pode ser uni ou bilateral, é assintomático e de etiologia incerta, mas que vem sendo atribuídas à alta ingestão de carboidratos, à regurgitação de conteúdos de ácidos gástricos, a alcalose metabólica e á má nutrição. Há ainda uma diminuição no fluxo salivar resultante de desidratação, má absorção, transtornos hormonais, anemia, má nutrição e uso de antidepressivos (TYLEND $\left.{ }^{164}, 1991\right)$.

Nos transtornos alimentares as complicações clínicas mais freqüentes estão associadas aos métodos compensatórios utilizados, a regurgitação corresponde a $80-90 \%$ dos casos, sendo sua prática de grande interesse odontológico por conferir várias alterações bucais (CALDEIRA; NÁPOLE; BUSSE ${ }^{42}$, 
2000). Pacientes com vômitos excessivos perdem grandes quantidades de líquidos e íons de hidrogênio, cloro e potássio. A irritação constante advinda da regurgitação causa aumento das papilas linguais, aumento assintomático das parótidas, xerostomia, irritação da mucosa oral, queilite e desgaste dentário, principalmente a erosão dental ou perimólise (ABOTT et al. ${ }^{1}$, 1993; HERZOG et al. ${ }^{79}$, 1993; FISHER; GOLDEN; KATZMAN ${ }^{64}$, 1995; EMANS ${ }^{58}$, 2000; PEGORARO; SAKAMOTO; DOMINGUES ${ }^{128}, 2000$; TRAEBERT; MOREIRA $\left.{ }^{163}, 2001\right)$.

A erosão dentária é considerada como lesão não cariosa ou desgaste dentário, esta é caracterizada pela perda da estrutura dentária e pode causar aos pacientes problemas estéticos e, principalmente, desconforto devido à hipersensibilidade que freqüentemente desenvolve-se na região cervical (LOZER, et al. $\left.{ }^{97}, 2000\right)$.

BURKE et al. $^{39}$, 1996, afirmam que a conseqüência dessa erosão dentária, pode causar várias complicações como: exposição pulpar; hipersensibilidade dentinária; diastemas; bordas incisais finas ou fraturadas; perda de dimensão vertical; proeminência das restaurações (aspecto esse garantido pelo menor efeito do ácido sobre a superfície do metal quando comparado ao efeito sobre a estrutura dentária); mordida aberta e comprometimento estético.

RYTÖMAA et al. $^{137}$, 1998, relatam que nem todos os bulímicos apresentam erosão dental e que os fatores associados com a ocorrência e a severidade da condição são o tempo de duração da doença, a freqüência dos episódios de vômito e a quantidade de saliva. A saliva reduz a acidez. Portanto, em pacientes com fluxo salivar baixo, a acidez permanece, principalmente no dorso da língua, razão pela qual as faces palatinas dos dentes anteriores são mais afetadas. Os autores relatam também desgastes dos dentes, principalmente relacionados à mastigação e à escovação vigorosa em pacientes bulímicos, após o episódio de vômito. Neste estudo, os pacientes bulímicos tiveram uma maior prevalência de cárie em superfícies proximais e palatinas do que pacientes controles, mas não houve diferença significativa nos hábitos de higiene e no estado periodontal.

Segundo MASO et al. ${ }^{106}$, 2001, durante um exame clínico, verificaram vários tipos de desgaste dentário e opacidades no esmalte dentário em 
determinadas regiões que seriam apenas observadas em pacientes com TAs que apresentam regurgitação gástrica. A manifestação bucal mais comum é a desmineralização, que é a perda do esmalte e/ou dentina nas superfícies dos dentes resultantes de uma ação química e mecânica. O paciente procura o profissional para aliviar a sensibilidade dentária associada por mudanças térmicas, fricção, dor espontânea ou a simples aparência dos dentes. A importância no diagnostico odontológico está no fato de que esse tipo de lesão é irreversível.

HAZELTON; FAINE ${ }^{77}$, 1996, relataram que um dos principais problemas para o dentista no trabalho com pacientes com desordens alimentares advém de seus problemas psicológicos. Normalmente, eles são bastante compulsivos em seus comportamentos diários. Sua higiene bucal é bastante meticulosa, repetitiva, e muitas vezes, seguida de escovações agressivas após o ato de vomitar, podendo resultar em severa abrasão. Nestes casos, o cirurgião-dentista deve alertar o paciente sobre o perigo destas escovações excessivas após o vômito e prescrever bochechos com água e bicarbonato de sódio para neutralizar o $\mathrm{pH}$ do ambiente bucal.

\subsubsection{Tratamento odontológico}

A perda de peso é o primeiro sintoma em pacientes com TAs, muitas vezes apresentam uma aparência física típica e característica, os quais apresentam também efeitos sobre a saúde bucal, cabendo ao cirurgião-dentista o conhecimento destas doenças, suas causas e efeitos, para que se possa diagnosticar e conduzir o tratamento adequado (BURKE et al. ${ }^{39}$, 1996).

O tratamento é sempre multiprofissional, com acompanhamentos médicos, nutricionais, psicológicos e odontológicos. Neste caso, o dentista irá tratar as conseqüências dos atos maléficos que esses transtornos causam nas estruturas dentárias, irá indicar métodos preventivos para evitar o aumento de cáries e erosões e orientar sobre o perigo de se desgaste dentário, com escovações excessivas, logo após ter provocado o vômito, já que este se apresenta desorganizado (SHAW; $\mathrm{SMITH}^{144}$, 1998). 
Na anamnese, é importante que o cirurgião-dentista tenha a habilidade de abordar o assunto de forma que se obtenha a confiança do paciente, inquirindo sobre os hábitos alimentares e a possibilidade de existência de problemas gastrointestinais, ao invés de dirigir perguntas diretas acerca da AN ou BN. Deve-se considerar que esta postura pode de certa forma, levar a resultados positivos do ponto de vista do tratamento do TA, pois possibilita a melhora de sua auto-estima por meio do tratamento odontológico do paciente ao longo do tempo, evitando a deterioração dos dentes (SCHMIDT; TREASURE $\left.{ }^{142}, 1997\right)$.

BURKE et al. $^{39}$, 1996 relatam que o manejo do paciente com TA em relação à saúde bucal deve envolver cuidados emergenciais, educação do paciente, cuidado pré-restaurador (ou adequação de meio), restaurações e manutenção. Dentre os cuidados emergenciais citados pode-se relacionar, procura pelo alívio da dor e melhora da estética. Como alívio da dor, propõe-se a proteção da dentina indevidamente exposta com a utilização de cimentos de ionômero de vidro, vernizes fluoretados ou, se necessário, tratamento endodôntico. Nos casos de queilite é indicado suplemento vitamínico; no bruxismo, confecção de placas miorelaxantes.

Para HAZELTON; FAINE $^{77}$, 1996, o planejamento do tratamento restaurador para esses pacientes é um desafio para o dentista. Se houver perda extensa de substância dental, o plano de tratamento normalmente deverá contemplar uma reabilitação bucal completa com restaurações bastante complexas. Mesmo com o intuito de melhorar a estética e de ser bastante cooperativo com as medidas preventivas prescritas, o paciente normalmente continua com seu hábito de vômito auto-induzido. Isto aumenta o risco de insucesso das restaurações, pelo fato de as estruturas dentais de suporte permanecerem em um ambiente extremamente ácido. Assim, também restaurações provisórias tendem a sofrer erosão muito facilmente se tal hábito permanecer.

PEGORARO; SAKAMOTO; DOMINGUES ${ }^{128}, 2000$ afirmam que é de suma importância o cirurgião-dentista orientar o paciente para não escovar os dentes imediatamente após a regurgitação, para não haver sinergismo do efeito erosivo e do mecânico, prescrever bochechos com água e bicarbonato de sódio para neutralizar o pH do ambiente bucal, além de aliviar a dor com a proteção do complexo dentinopulpar exposto, com a utilização de cimentos de ionômero de vidro, 
vernizes fluoretados, ou se necessário, tratamento endodôntico. Ainda, prescrever a utilização de cremes dentais com alta concentração de flúor e baixa abrasividade e realizar aconselhamento dietético no sentido de evitar alimentos e bebidas ácidas. Soluções neutras de flúor a 0,05\% também são úteis na redução da erosão e da sensibilidade subseqüente.

É fundamental uma abordagem de educação alimentar e saúde bucal concomitante ao tratamento restaurador, principalmente entre pacientes com má higiene bucal e ataques cariogênicos severos devido à ingestão de grandes quantidades de carboidratos. Em pacientes sem esses problemas, a educação em saúde bucal deve enfocar o aumento de conhecimento sobre sua situação e os riscos dela decorrentes (TRAEBERT; MOREIRA ${ }^{163}, 2001$ ).

O tratamento restaurador deve ser realizado como forma de auxiliar o tratamento psicológico, na tentativa de aumentar a auto-estima do paciente já que muitos só procuram o dentista quando há comprometimento estético, podendo variar de uma simples restauração até reabilitações bucais complexas em pacientes com perda da dimensão vertical. As coroas de cerâmica pura, cimentadas sobre a dentina remanescente com material adesivo, são relatadas como boa alternativa em casos onde o paciente continua com hábito de vômito auto-induzido e o insucesso das restaurações diretas nestes pacientes se devem ao fato das estruturas de suporte permanecem em um ambiente extremamente ácido, já que estas não são solúveis em ácido. O tratamento deve ter como objetivo cobrir tecido dentinário exposto para evitar perdas ainda maiores de tecido dentário (BURKE et al. ${ }^{39}$, 1996; TRAEBERT; MOREIRA ${ }^{163}$, 2001).

O tratamento deve ser de acordo com a severidade do caso. Em pacientes com esmalte poroso na região cervical e sem sensibilidade, recomenda-se aplicações tópicas de flúor periódicas além do controle da dieta. Nos pacientes com cavidade em esmalte e dentina e com sensibilidade dentária, restaurações com ionômero de vidro e resina. Nos casos crônicos e severos, com perda de esmalte, dentina, sensibilidade dentária, patologia pulpar e dano estético, deve-se realizar o tratamento endodôntico e reabilitação protética, no menor número de sessões possível para diminuir a ansiedade do paciente e recuperar sua auto-estima (MASO et al. $\left.{ }^{106}, 2001\right)$. 
O aconselhamento dietético no sentido de evitar alimentos e bebidas ácidas, reduzindo a freqüência de sua ingestão, principalmente como última ingestão noturna, tem sido relatado como importante contribuição no tratamento dos pacientes acometidos pelas doenças (SHAW; SMITH $\left.{ }^{144}, 1998\right)$.

O cirurgião-dentista deve abordar os pacientes cuidadosamente, catalogá-los e fotografá-los. Alertá-los quanto danos das práticas nocivas que realizam à saúde bucal, para que aumentem o cuidado com a higiene bucal e tentem modificar seus hábitos. A correção desses problemas pode ajudar o paciente no aspecto estético e psicológico. Um tratamento simples, como uma restauração, melhora a auto-estima dessas pessoas. Não há diferença entre o trabalho de restauração feito em pacientes com TAs e o realizado por outros motivos. No entanto, é preciso ir além, aliando o tratamento odontológico ao psicológico, porque uma abordagem equivocada pode piorar o estado emocional debilitado do paciente (LEITE; PINTO ${ }^{92}$, 2001).

É de fundamental importância a participação do cirurgião-dentista na equipe multiprofissional, onde poderá auxiliar no diagnóstico e no tratamento das lesões da boca, proporcionando benefícios à saúde bucal e geral destes pacientes (TRAEBERT; MOREIRA ${ }^{163}, 2001$ ).

O tratamento de pacientes com transtornos alimentares deve ser realizado por uma equipe multiprofissional, formada por profissionais da saúde (médicos, nutricionistas, psicoterapeutas), que atuem com adolescentes e adultos jovens. Todos os membros da equipe devem estar aptos a identificar o problema, a realizar uma adequada avaliação nutricional, identificar e tratar as complicações clínicas mais freqüentes oferecendo o correto acompanhamento dos pacientes (LEITE; PINTO ${ }^{92}$, 2001; TRAEBERT; MOREIRA ${ }^{163}, 2001$ ). 


\subsection{DESGASTE DENTÁRIO}

Atualmente, os cirurgiões-dentistas estão observando um paradoxo: dentes saudáveis e duradouros estão cada vez mais mostrando sinais de desgaste. A crescente longevidade no século XXI significará maior manutenção dos dentes o que resultara em efeitos incrementais e clinicamente perniciosos do desgaste, especialmente causados por erosão. Os problemas bucais podem ser divididos em lesões cariosas e não cariosas, sendo que o desgaste dentário está incluído nesta última (ZERO; LUSSI ${ }^{174}$, 2005; BARTLETT ${ }^{25}$, 2005).

O desgaste dentário (DD) é um termo composto, introduzido para abranger a perda de estrutura na superfície dentária não cariada causada por abfração, abrasão, atrição e erosão dentária. É comumente originado por uma combinação de causas, sendo que uma boa comunicação entre o paciente e o dentista é fundamental para a determinação da etiologia do caso e discussão das formas de prevenção e tratamento para o mesmo $\left(\mathrm{SMITH}^{148}, 1989\right)$.

Segundo MONDELLI ${ }^{110}$, 2003, o desgaste dentário pode ser definido como uma perda gradual não-cariosa de estrutura dos dentes, devido ao contato físico repetitivo ou ataque químico, podendo também ser denominada de lesões não cariosas (LNC).

A perda de substância dentária superficial pode ocorrer como resultado de agentes físicos (abrasão e atrição) e químicos (erosão). Geralmente mais de um desses fatores acomete a estrutura dentária ao mesmo tempo, o que torna o diagnóstico bastante complexo. Esta é uma perda de estrutura que ocorre sem sofrer influencia direta da ação do biofilme dentário e algum grau deste desgaste é aceito como fisiológico. Apenas quando o DD é excessivo afetando a estética ou a função dos dentes, ou causa desconforto e/ou dor, é que este deve ser considerado patológico (ECCLES $\left.{ }^{57}, 1982\right)$.

Segundo SMITH; ROBB ${ }^{151}$, 1996, consideraram o DD um problema comum, cuja prevalência gira em torno de $97 \%$ de acometimento da população, independente da faixa etária considerada. 
Frente ao DD, a forma do dente é perdida assim como sua função é alterada. De acordo com BARTLETT; PHILLIPS; SMITH ${ }^{26}$, 1999, a hipersensibilidade a mudanças de temperatura pode ser observada pela evolução da erosão exposição dos túbulos dentinários ao ambiente bucal. Mas, se o desgaste é gradativo e lento, a polpa pode responder com a formação de dentina secundária e a sensibilidade não será um problema comum, mesmo nos casos mais avançados, particularmente, nos pacientes mais velhos.

De acordo com o conhecimento vigente, o DD em qualquer indivíduo tende a ser multifatorial, sendo dificilmente ocasionado por um único fator etiológico (BARTLET; PHILLIPS; SMITH ${ }^{26}$, 1999; IMFELD ${ }^{83}$, 1996; LAMBRECHTS et al. ${ }^{88}$, 1996; MILLWARD et al. ${ }^{109}$, 1994). Uma causa, entretanto, deve ser predominante. Para um cirurgião-dentista é importante detectar o principal motivo de DD para a implementação de medidas preventivas adequadas (HOOPER et al. ${ }^{82}$, 2004; LUSSI; JAEGGI; ZERO ${ }^{101}$, 2004).

Determinar a etiologia do DD não é fácil, sendo geralmente baseada na aparência clínica. O desgaste das superfícies oclusais é diagnosticado como atrição, mas em muitos casos uma investigação mais detalhada revela também um componente erosivo nesta causa. O termo desgaste dentário tende a englobar todas as condições (erosão, atrição, abrasão e possivelmente abfração), mais suas combinações, sendo que a causa pode ser ou não conhecida. O termo "desgaste dentário" parece ser abrangente para descrever o processo combinado de perda de estrutura dos dentes por erosão, abrasão, abfração e atrição, ou quando um diagnóstico específico não puder ser determinado. Este deve ser usado como uma descrição genérica para os sinais e danos provocados até que um diagnóstico mais específico da etiologia possa ser feito (SMITH; KNIGHT $\left.{ }^{150}, 1984\right)$.

Apenas por meio de uma boa anamnese, análise da aparência do desgaste e consideração à etiologia do mesmo é que um diagnóstico específico será possível. Caso isso não seja alcançado, o termo genérico "desgaste dentário" deveria ser utilizado (BARTLETT; PHILLIPS; SMITH $\left.{ }^{26}, 1999\right)$.

Entretanto, até mesmo uma história abrangente e um bom exame baseado em evidências científicas podem falhar no esclarecimento da causa do DD, 
demonstrando a necessidade de mais pesquisas clínicas relacionadas à etiologia dos mesmos e dos mecanismos pelos quais eles ocorrem (SMITH; KNIGHT ${ }^{150}$, 1984).

A literatura científica classifica a perda de estrutura dentária de etiologia não cariosa em: Abfração (perda patológica de tecido duro do dente, causada por forças biomecânicas, que ocorreriam pela flexão e fadiga do esmalte e dentina em um ponto distante do ponto de aplicação das forças); Abrasão (perda de estrutura dentária por meio mecânico como a escovação); Atrição (perda de estrutura dentária por contato funcional ou parafuncional como mastigação normal e bruxismo); Erosão (perda de estrutura dentária por processo químico ou idiopático) (BARATA; FERNANDES; FERNANDES ${ }^{22}$, 2000).

As terminologias para os diferentes tipos de desgastes ou perda da estrutura dentária e respectivas definições, de acordo com mecanismos etiológicos, estão dispostas na Figura 3.

Segundo LEVITCH et al. ${ }^{93}$, 1994, relatam existir suficientes evidencias para suportar a etiologia multifatorial da LNC, que podem vaiar seu aspecto morfológico, desde lesões raras e extensas até lesões profundas em forma de cunha com ângulos nítidos ou com margens mal definidas. As lesões podem ocorrer tanto nas faces vestibular, lingual e incisal/oclusal.

\begin{tabular}{c|l}
\hline Terminologia & \multicolumn{1}{c}{ Definição } \\
\hline Abfração & $\begin{array}{l}\text { Perda de estrutura dentária da região cervical como resultado de forças } \\
\text { oclusais aplicadas centricamente ou excentricamente (contatos exagerados e } \\
\text { deflectivos) que provocam deflexão no colo do dente. }\end{array}$ \\
\hline Abrasão & $\begin{array}{l}\text { Perda da estrutura dentária ou da restauração por processos mecânicos } \\
\text { anormais (não de contatos entre dentes), envolvendo objetos ou substâncias } \\
\text { estranhas repetidamente introduzidas na boca e contatando os dentes } \\
\text { (escovação, roer unha, morder lápis, etc.). }\end{array}$ \\
\hline Atrição & $\begin{array}{l}\text { Perda de estrutura dentária ou da restauração causada pelo contato dente a } \\
\text { dente ou entre dentes opostos, sem nenhuma substância estranha interposta. }\end{array}$ \\
\hline Erosão & $\begin{array}{l}\text { Perda progressiva da estrutura dentária por processo químico pela ação de } \\
\text { ácidos de origem não bacteriana (sucos cítricos e gástrico, refrigerantes, etc.). }\end{array}$
\end{tabular}

Figura 3 - Terminologia e definição dos diversos tipos de desgaste dentário. 


\subsubsection{Abfração}

Em 1991, GRIPPO ${ }^{71}$, propôs o termo abfração para as lesões em esmalte e dentina resultantes de stress originado de forças biomecânicas nas superfícies dentais, pode ser encontrada em um dente isoladamente ou em dentes não adjacentes. Essa denominação é originada do termo latino "abfraction" - "ab" significa para fora e "fraction", ruptura, sendo definida como perda patológica de substância dentária, causada por forças biomecânicas, devido à flexão da estrutura dentária e resultando em fadiga da dentina e esmalte na região do fulcro. Essas forças são focadas na junção cemento-esmalte, onde provocam microfraturas no esmalte e na dentina. Essas microfraturas se propagam perpendicularmente ao longo eixo do dente afetado até que haja fratura da superfície dentária. Os defeitos resultantes em forma de cunha apresentam margens cortantes.

Alguns autores relataram que grandes estresses por tensão pelas cargas oclusais podem causar uma perda da estrutura dentária. Quando a mastigação não é correta, forças laterais aparecem, fazendo com que o dente se "curve", produzindo uma distribuição de forças com estresse na junção amelocementária, o que pode causar ruptura das ligações químicas nas estruturas cristalinas do esmalte e dentina, resultando em uma separação entre eles (LEE; EAKLE ${ }^{91}$, 1984; TANAKA et al. ${ }^{160}$, 2003).

Lesões de abfração (Figura 4) podem ser observadas também em pacientes com bruxismo, onde, acredita-se que as forças das interações entre dentes antagonistas, promovem as facetas de desgaste nas faces oclusais pela atrição, desenvolvem as lesões em forma de cunha nos mesmos dentes. A fratura do esmalte e dentina cervicais é produzida patologicamente por esse mecanismo chamado abfração, e tem sido atribuído ao estresse da corrosão gerado nessas áreas (BARTLETT; PHILLIPS; SMITH $\left.{ }^{26}, 1999\right)$. 




Figura 4 - Lesão de abfração

Clinicamente as lesões de abfração (Figura 5) são descritas como sendo agudas e em forma de cunha, geralmente profundas e com margem bem definidas, acometendo a região cervical dos dentes afetados. A maior incidência pode ser encontrada nos dentes inferiores e estar relacionada ao menor diâmetro coronário em cervical, quando comparado aos superiores (IMFELD ${ }^{83}$, 1996). Tem sido comumente, observadas em pacientes com bruxismo ou interferência oclusal pela acentuada distribuição de cargas. Recentes estudos apontaram não só a hipótese puramente mecânica e sugerem que as lesões de abfração (Figura 6) são multifatoriais, havendo uma inter-relação entre as forças oclusais, as abrasivas e a dieta ácida erosiva (HAMMADEH; REES $\left.{ }^{74}, 2001\right)$.

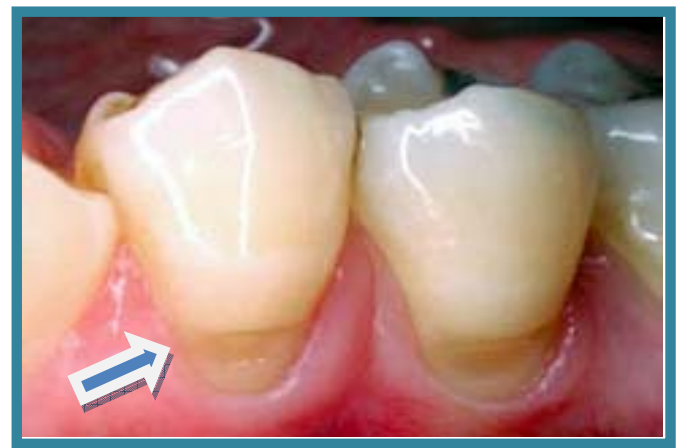

Figura 5 - Lesão de abfração



Figura 6 - Lesão de abfração 



\subsubsection{Abrasão}

O termo abrasão deriva do latim abradere, abrasi, abrasum, e descreve a perda de substância por desgaste decorrente de processos mecânicos, como triturar, friccionar ou despedaçar. O termo clínico abrasão dentária é usado para descrever o desgaste patológico dos tecidos duros dentários por meio de forças mecânicas anormais que envolvem objetos estranhos ou substâncias repetidamente introduzidas no ambiente bucal e tocando os dentes. O padrão de desgaste dentário pode ser difuso ou localizado, dependendo da etiologia (ECCLES ${ }^{57}$, 1982).

Os hábitos que causam abrasão são: fumar cachimbo, quebrar sementes ou nozes com os dentes, roer unha, segurar grampos para cabelos com os dentes, etc. Os profissionais como carpinteiro, alfaiates, músicos que, habitualmente, seguram ou forçam objetos entre os dentes mostram evidencias de abrasão dentária (ECCLES $\left.{ }^{57}, 1982\right)$.

Segundo OGINNI; OLUSILE ${ }^{122}$, 2002, relatam que abrasão dentária também pode ser causada pelo uso incorreto de palito e fio-dental, portanto, dentre os fatores considerados como causa deste tipo de desgaste dentário, a escovação se mostrou a mais prevalente, dependendo de fatores como, técnica inadequada de escovação dentária, tipos de cerdas da escova dentária utilizada e abrasividade dos dentifrícios. Com relação às técnicas de escovação, na técnica vertical as cerdas permanecem menos tempo em contato com a estrutura dentária comparada à técnica de escovação horizontal. Quanto ao design das cerdas da escova dentária, estudos "in vitro" demonstraram que o tipo de filamento das cerdas determina variação na habilidade de transportar o creme dental e, conseqüentemente, causar abrasão dentária à superfície dos dentes.

Clinicamente a abrasão (Figura 7) é mais observada na região cervical dos dentes e se manifesta como lesões de aspecto arredondado ou em forma de sulcos em V, entre a gengiva e o esmalte da coroa. Na lesão de abrasão crônica, pela escovação, podemos verificar uma superfície lisa, aspecto polido, com esmalte e dentina caracterizados por estrias horizontais uniformes e consistentes (SMITH ${ }^{148}$, 1989). 





Figura 7 - Lesão de abrasão

Esse tipo de DD por abrasão (Figura 8) pode acometer qualquer dente, mas comumente aparecem na região cervical vestibular dos dentes que são proeminentes no arco, como os incisivos, caninos e pré-molares, em ambos os arcos dentários e também se manifestam nos dentes adjacentes a áreas edêntulas (ADDY; MOSTAFA; NEWCOMBRE², 1987).

A posição do dente no arco também é relevante à distribuição de abrasão (Figura 9), sendo que os dentes vestibularizados são mais suscetíveis ao desgaste e ao trauma que aqueles posicionados mais lingualmente (ADDY; MOSTAFA; NEWCOMBRE $\left.{ }^{2}, 1987\right)$.

Segundo LITONJUA et al. $^{95}$, 2003, as pessoas destras mostram uma preponderância de lesões no lado esquerdo da boca, enquanto canhotos mostram o oposto. A seqüência na qual os dentes são escovados também se relaciona com a localização das lesões de abrasão.

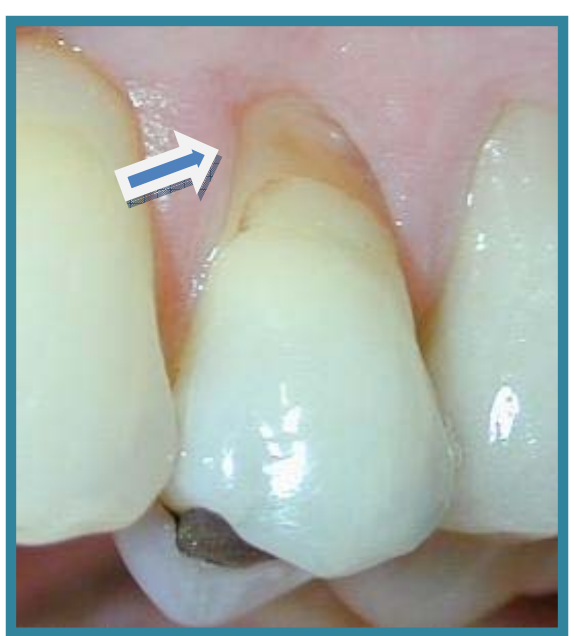

Figura 8 - Lesão de abrasão

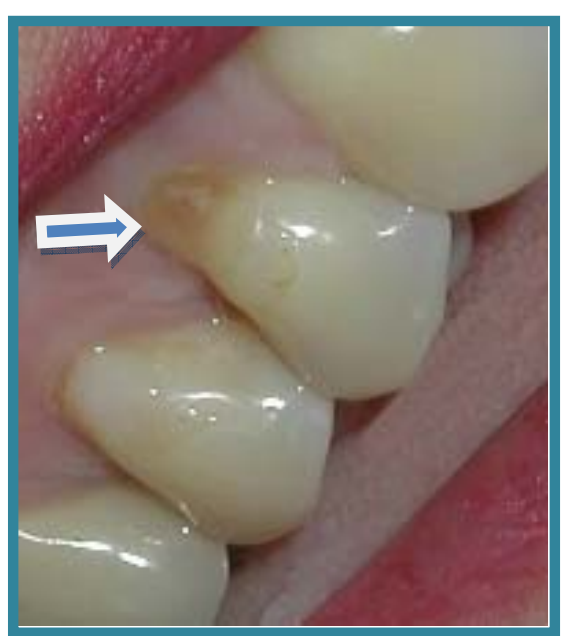

Figura 9 - Lesão de abrasão 



\subsubsection{Atrição}

O termo atrição é derivado do latim atterere, attrivi, attritum descrevendo a ação do contato contra alguma coisa. O termo atrição dentária é usado para descrever o desgaste fisiológico do tecido duro dentário com resultado do contato entre os dentes antagonistas, sem intervenção de qualquer outro objeto. Esse contato ocorre durante a raspagem de um dente contra outro, trituração e fala, e o resultado do desgaste envolve as superfícies oclusais e incisais dos dentes. As faces proximais também podem ser envolvidas durante a mastigação. O grau individual de desgaste está diretamente relacionado com a idade. O desgaste em esmalte apresenta-se plano e na dentina, raso. Haverá freqüentemente contorno assimétrico na região de contato entre dentes antagonistas nos movimentos. A lesão de atrição (Figura 10) é muitas vezes confundida com outras alterações e motivo de dúvidas (SMITH ${ }^{148}, 1989$; LOZER et al. $\left.{ }^{97}, 2000\right)$.



Figura 10 - Lesão de atrição

Esse tipo de DD ocorre usualmente nas superfícies oclusais, incisais ou palatinas dos dentes superiores, ou na superfície vestibular dos dentes inferiores, apresentando uma pequena área polida na ponta da cúspide, na região ao redor dela ou nos ângulos incisais. Alguns hábitos funcionais ou parafuncionais, incluindo a mastigação, o bruxismo e apertamento dentário, podem contribuir para esse tipo de desgaste (Figura 11). Os indivíduos que têm uma dieta abrasiva, primitiva, contendo impurezas, apresentam maiores chances de apresentar esse desgaste. A quantidade de contato que ocorre entre dois dentes, durante a alimentação com uma dieta moderna, é provavelmente insuficiente para causar atrição (Figura 12) mesmo que ao longo do tempo (BARTLETT; PHILLIPS; SMITH ${ }^{26}, 1999$ ). 



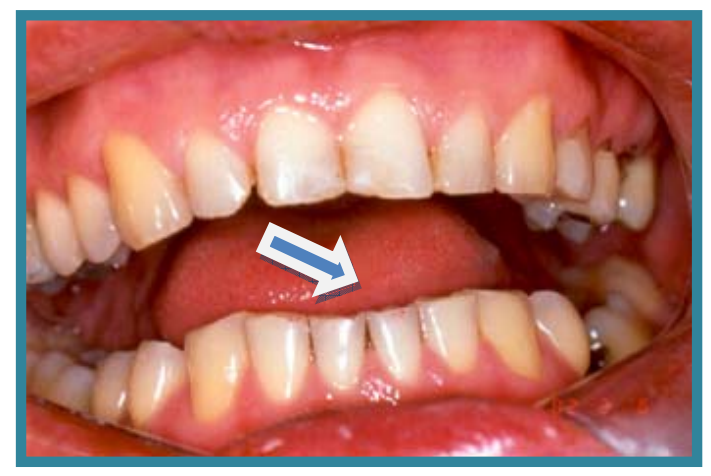

Figura 11 - Lesão de atrição

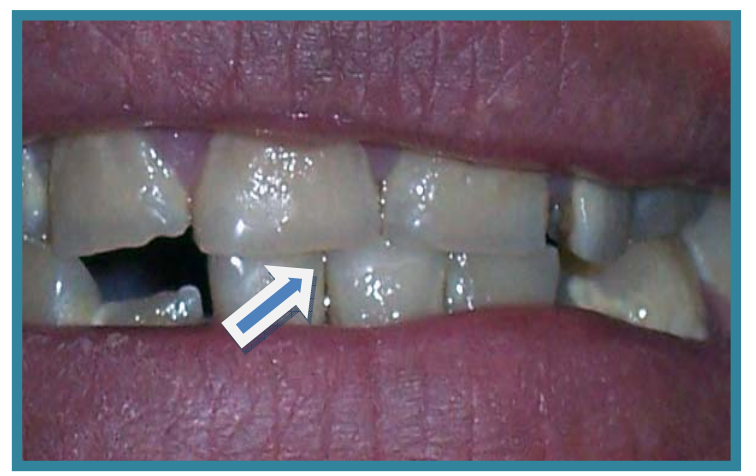

Figura 12 - Lesão de atrição

A atrição possui uma etiologia multifatorial. Experimentos in vitro mostraram que o desgaste de esmalte é afetado por mudanças nas condições de lubrificação pela saliva, acidez do meio bucal e a ocorrência de cargas ou forças oclusais. O desgaste do esmalte difere do desgaste da dentina, sendo que, o aumento progressivo da dentina é associado ao aumento de forças oclusais, sendo a atrição um processo contínuo (LITONJUA et al. ${ }^{95}, 2003$ ).

\subsubsection{Erosão}

O termo erosão é derivado do latim erodere, erosi, erosum, que descreve o processo gradual de destruição de uma superfície, usualmente por um processo químico ou eletrolítico (LITONJUA et al. ${ }^{95}, 2003$ ).

Definida como perda patológica, crônica, indolor e localizada no tecido dentário duro submetido quimicamente ao ataque de ácidos sem o envolvimento de bactérias, a erosão dentária (Figura 13) pode ser causada por uma série de fatores extrínsecos ou intrínsecos (BARATIERI $\left.{ }^{23}, 2001\right)$.

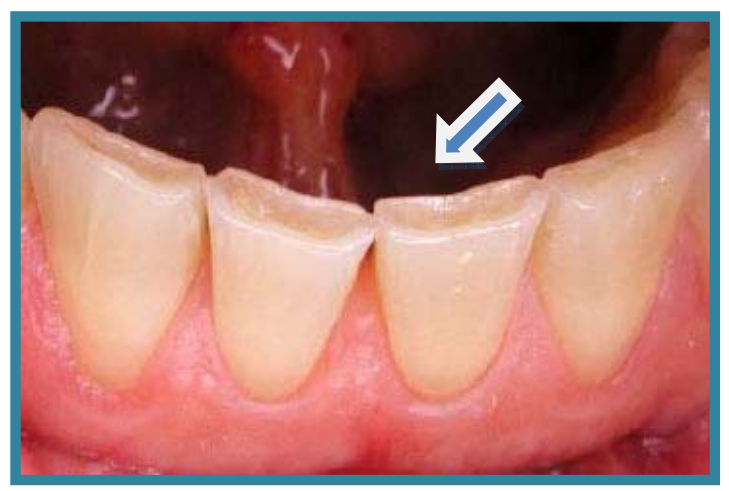

Figura 13 - Lesão de erosão 



\subsubsection{Erosão extrínseca}

A erosão extrínseca é o resultado da ação de ácidos exógenos que entram em contato com a cavidade bucal por via oral. Podem estar presentes na atmosfera do ambiente de trabalho, algumas vezes sendo considerados como ácidos industriais, ou ácidos da água de piscinas, como efeito do uso de gás de cloro que reage com a água formando o ácido hidroclorídrico. Funcionários de fábricas de baterias, aqueles que se encontram expostos a processos eletrolíticos e também outros trabalhadores que ficam numa atmosfera contaminada por vapor ácido tendem a apresentar lesões de erosão dentária (BARTLETT; PHILLIPS; $\mathrm{SMITH}^{26}$, 1999).

Severos casos de erosão extrínseca têm sido relacionados à administração oral de medicamentos, como os tônicos de ferro, reposição ácida de pacientes que sofrem de acloridria; ou os ácidos para dissolver pequenos cálculos renais $\left(\right.$ ZERO $\left.^{173}, 1996\right)$.

Os ácidos da dieta são, entretanto, o principal fator etiológico da erosão dentária extrínseca (Figura 14). As fontes extrínsecas de ácidos disponíveis são muitas e variadas, mas têm sido consideradas pela mídia e mesmo pelos estudos disponíveis na literatura que o enorme aumento no consumo de bebidas carbonatadas pode ser o principal fator na erosão, nos últimos 25 anos (AIDLAIGAN; SHAW; SMITH $\left.{ }^{3}, 2001\right)$.

Provavelmente pelo aumento do número de pessoas praticando exercícios físicos, geralmente prolongados, regulares e intensos, houve a introdução do consumo de bebidas esportivas. Essas bebidas apresentam geralmente um baixo $\mathrm{pH}$ e uma acidez variável, sendo ambas as propriedades relevantes frente ao processo de erosão dentária. Recentemente, as bebidas convencionais têm sido modificadas pela adição de cálcio às mesmas com a finalidade de reduzir o potencial erosivo. Os isotônicos esportivos, geralmente, apresentam um baixo pH e contêm açúcar para proporcionar energia (mistura de 6 a 7\% de glicose) e eletrólitos para reposição daqueles perdidos com o suor. Durante os exercícios físicos pode ocorre desidratação, resultando em redução do fluxo salivar, aumentando o potencial para 

contribuir na ocorrência de erosão dentária (Figura 15) e no processo cariogênico. A xerostomia também ocorre durante a realização dos exercícios, podendo aumentar a suscetibilidade à erosão que acontece pelo consumo dessas bebidas. Muitos esportes envolvem o treino constante e prolongado, onde grandes quantidades de bebidas são consumidas, expondo a cavidade bucal à erosão dentária por repetidos períodos de ingestão (HOOPER et al. ${ }^{82}$, 2004).

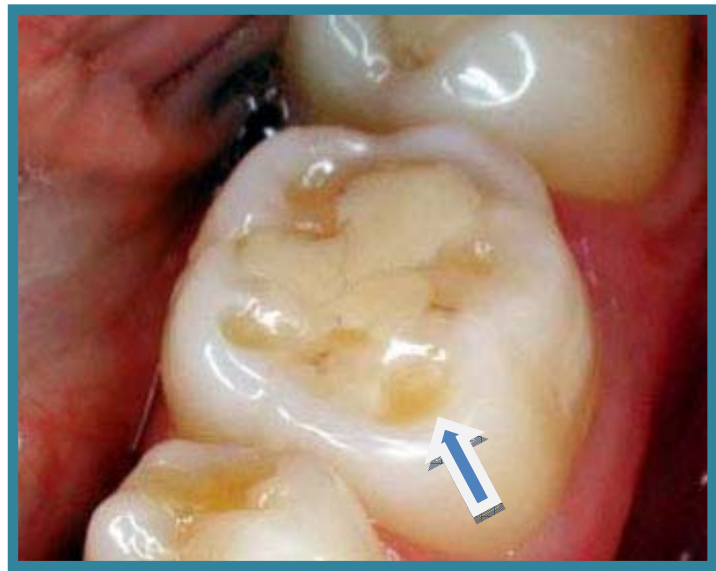

Figura 14 - Lesão de erosão

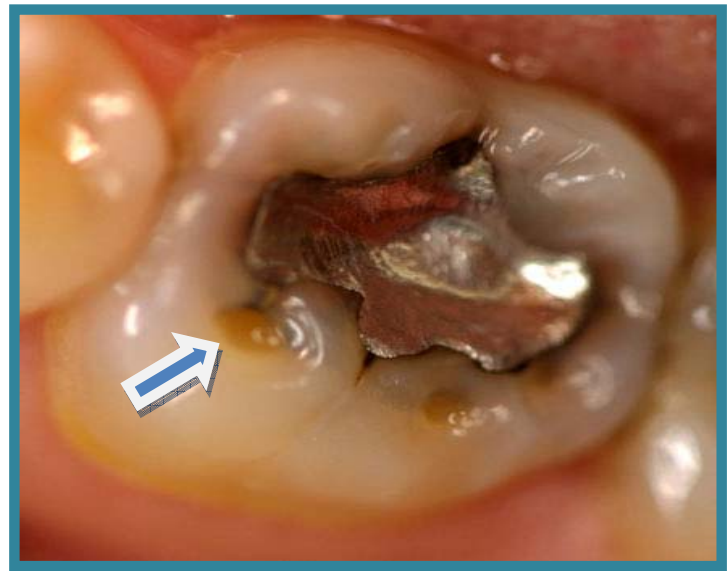

Figura 15 - Lesão de erosão

Diferentes estudos mostraram que a dieta pode ser um importante fator etiológico ao desenvolvimento e progressão da erosão dentária (Figura 16). O consumo freqüente de sucos de frutas e bebidas ácidas causa erosão dentária, quando sob circunstâncias desfavoráveis na cavidade bucal. Tem sido verificado também que bebidas contendo ácido cítrico são mais erosivas do que as contendo ácido fosfórico, mas resultados contrários têm sido publicados (LUSSI; JAEGGI; SCHARER $^{100}$, 1993; AINE; BAER; MAKI ${ }^{4}, 1993$; IMFELD ${ }^{83}, 1996 ;$ ZERO $\left.^{173}, 1996\right)$.

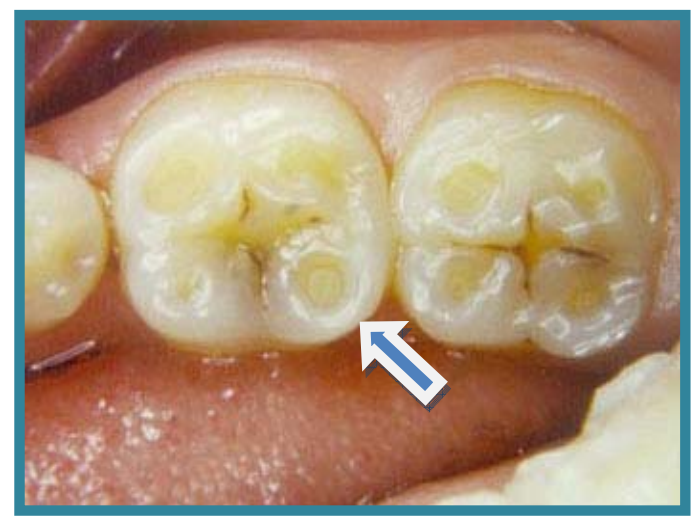

Figura 16 - Lesão de erosão

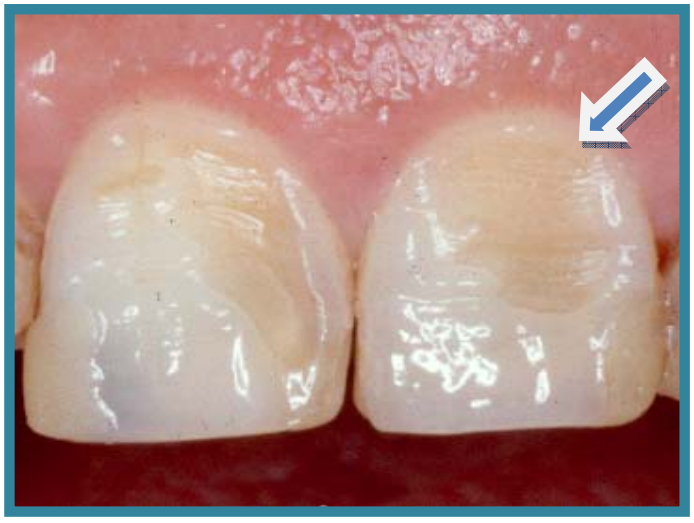

Figura 17 - Lesão de erosão 

Um dos mais potentes agentes erosivos encontrados nos alimentos é o ácido cítrico, em decorrência da sua propriedade de quelar o cálcio da hidroxiapatita, aumentando a suscetibilidade à dissolução. Essa capacidade tende a continuar, mesmo depois que o $\mathrm{pH}$ se eleva a níveis normais, prolongando a erosão dentária (LUSSI $^{99}, 1996 ;$ ZERO $\left.^{173}, 1996\right)$.

Segundo GIUNTA ${ }^{68}$, 1983; MEURMAN; FRANK ${ }^{108}$, 1991, a erosão dentária pode ser causada por ácido cítrico de vitamina C e bebidas. Outros fatores, além do consumo de bebidas ácidas, como a capacidade tampão da saliva e o estado físico do dente devem ser considerados nos diferentes graus de erosão observados em cada individuo.

Em adicional, alimentos e bebidas ácidas podem promover o refluxo gastro-esofágico tendo o potencial de causar erosão dentária por regurgitação. Pacientes consumidores de chá de ervas, alguns profissionais relataram uma maior tendência de se encontrar superfícies perdidas pela erosão dentária e a severidade desta parece ser inversamente proporcional ao $\mathrm{pH}$ do chá (BRUTON; HUSSAIN ${ }^{36}$, 2001).

\subsubsection{Erosão intrínseca}

A erosão intrínseca (Figura 18) é o resultado de ácidos endógenos, como o ácido gástrico que atinge a cavidade bucal durante o vômito, regurgitação, ruminação ou refluxo. Transtornos alimentares como, o vômito decorrente da anorexia e bulimia nervosa, são freqüentemente as causas de regurgitação ou vômito induzido. O sintoma clínico associado a este fenômeno é a regurgitação de ácidos e, conseqüentemente a azia. A ruminação consiste na regurgitação espontânea repetitiva de alimentos não digeridos, minutos após as refeições. O alimento é remastigado deglutido novamente ou, ás vezes, escarrado (MALCOLM ${ }^{105}$, 1997).

A regurgitação crônica, de origem somática ou psicossomática é a segunda principal causa de desgaste por erosão, resulta em uma distribuição típica das lesões de erosões pelos arcos dentários. Este achado clínico tem sido chamado 

de perimólise. Correspondendo a regurgitação de ácido gástrico sobre o dorso da língua, sobre as faces palatinas dos dentes superiores e sobre a face oclusal dos dentes inferiores, a perimólise afeta os dentes superiores e inferiores de forma diferente. Outra característica dela é que as restaurações permanecem intactas e se projetam acima da superfície dentária remanescente (IMFELD $\left.{ }^{83}, 1996\right)$.

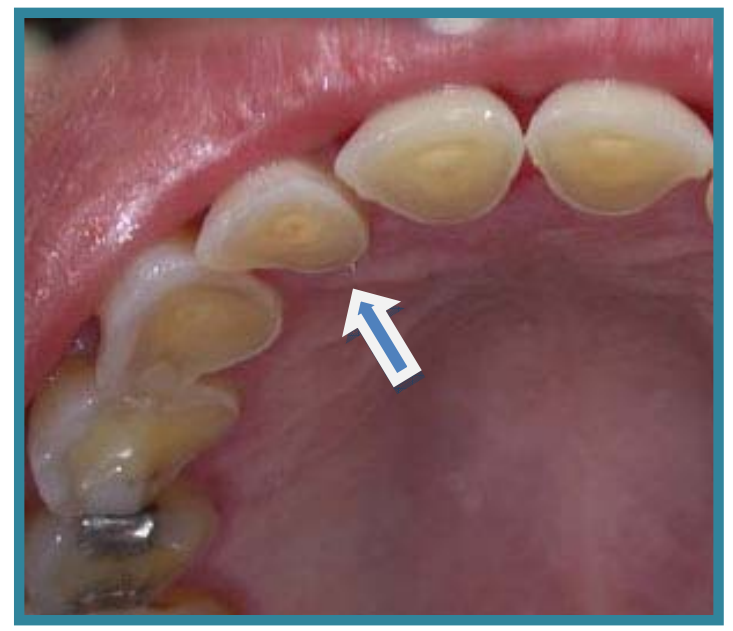

Figura 18 - Lesão de erosão

As causas de origem somática incluem algumas condições médicas como desordens gastrointestinais (úlcera péptica, hérnia de hiato, problemas de mobilidade gástrica, obstrução intestinal, gastrenterites) metabólicas e endócrinas (diabetes melitus e deficiência renal, hipertireoidismo, insuficiência adrenal) neurológicas e do sistema nervoso (enxaquecas, neoplasias intracranianas) podem ocasionar processos de vômitos recorrentes, aumentando assim a probabilidade de incidência de lesões erosivas dentárias (Figura 19). Os pacientes que apresentam história de alcoolismo crônico também podem apresentar vômito recorrente e geralmente associado ao refluxo gastro-esofágico. A gravidez é uma condição que predispõe a constantes crises de vômitos (IMFELD ${ }^{83}$, 1996; ROBB; SMITH $\left.{ }^{133}, 1990\right)$.

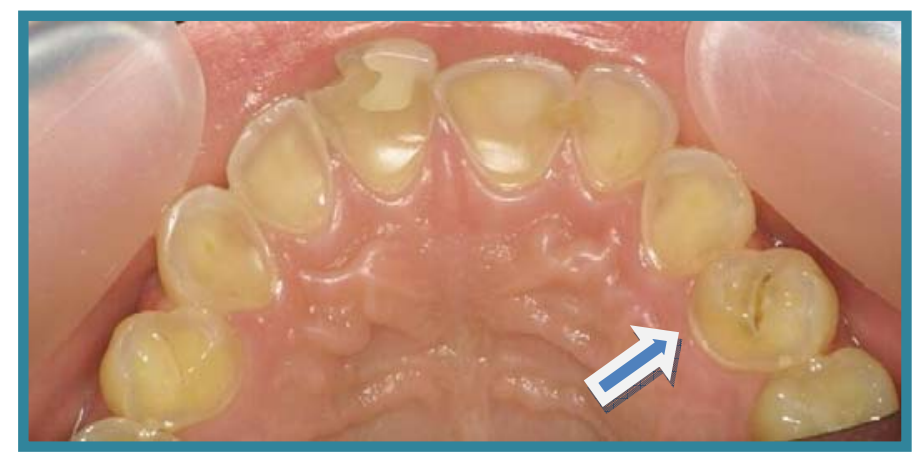

Figura 19 - Lesão de erosão 

O processo erosivo é influenciado pelo que ocorre antes, durante e depois do desafio ácido, isto é, da completa inter-relação entre fatores biológicos e comportamentais, em função do tempo. Assim, fatores biológicos como o fluxo salivar, composição, capacidade tampão e pH da saliva, presença ou não de película adquirida, composição e estrutura dentária e anatomia e oclusão dentária interferem no possível desenvolvimento do processo da erosão dentária (BARTLETT ${ }^{25}$, 2005; MOSS $^{115}, 2006$ ).

O mecanismo de desenvolvimento da erosão dentária ainda está diretamente relacionado aos constituintes da cavidade bucal. A saliva atua como tampão para os ácidos desmineralizantes em superfícies dentárias. Contudo, baixo fluxo salivar pode, portanto, ser um fator desencadeador na erosão dentária. Indivíduos com baixos níveis de fluxo salivar correram cinco vezes mais o risco de desenvolver lesões de erosão dentária (LITONJUA et al. ${ }^{95}, 2003$ ).

Como conseqüência da erosão dentária, pode ocorrer exposição pulpar; hipersensibilidade dentinária; diastemas; bordas incisais finas ou fraturadas; proeminência das restaurações (aspecto esse garantido pelo menor efeito do ácido sobre a superfície do metal quando comparado ao efeito sobre a estrutura dentária), pseudomordida aberta e comprometimento estético. Além disto, pode ocorrer perda de dimensão vertical, devido ao desgaste das superfícies oclusais dos dentes posteriores (BURKE et al. $\left.{ }^{39}, 1996\right)$.

\subsection{5 Índice de desgaste dentário}

A inexistência de um índice para mensuração da severidade das lesões internacionalmente aceito torna-se um obstáculo para o estudo da etiologia do desgaste dentário.

Nos últimos anos, têm-se buscado formas de obtenção de um diagnóstico claro e preciso acerca da prevalência de erosão dentária em diferentes populações, através da utilização de índices epidemiológicos. Vários índices têm sido propostos, porém, há uma grande dificuldade em se medir a erosão dentária. 
TEN CATE; IMFELD ${ }^{162}$, em 1996, descreveram um índice de desgaste dentário, para ser utilizado em larga escala em estudos epidemiológicos, ou monitorar a progressão da lesão ao longo do tempo. Baseado em um escore de severidade para superfície vestibular e outro para superfície palatal e oclusal conforme apresentado na tabela 1.

Tabela 1 - Índice de desgaste dentário proposto por Ten Cate; Imfeld, em 1996.

\begin{tabular}{|c|c|}
\hline Superfície vestibular & Superfície palatal ou oclusal \\
\hline 0 - nenhum sinal de erosão & $0-$ nenhum sinal de erosão \\
\hline 1 - somente em esmalte & 1 - somente em esmalte \\
\hline 2 - metade da dentina & $3-$ esmalte e dentina \\
\hline 3 - grande extensão da dentina & \\
\hline
\end{tabular}

Algumas classificações para a erosão dentária foram elaboradas a fim de facilitar o estudo. ECCLES ${ }^{56}, 1979$, sugeriu a classificação baseada na severidade clínica que pode ser encontrada na tabela 2.

Tabela 2 - Classificação da erosão dentária preconizada por Eccles, 1979.

\begin{tabular}{|c|c|}
\hline Classificação & Severidade da Lesão \\
\hline Classe I & Lesões superficiais - envolvendo somente esmalte. \\
\hline Classe II & $\begin{array}{l}\text { Lesões localizadas - envolvendo dentina em menos que } 1 / 3 \text { da } \\
\text { superfície. }\end{array}$ \\
\hline Classe III & $\begin{array}{l}\text { Lesões generalizadas - envolvendo dentina em mais que } 1 / 3 \text { da } \\
\text { superfície. } \\
\text { III - a: superfícies vestibulares } \\
\text { III - b: superfícies linguais e palatinas; } \\
\text { III - c: superfícies incisais e oclusais; } \\
\text { III - d: múltiplas superfícies envolvidas severamente. }\end{array}$ \\
\hline
\end{tabular}


Em 1984, SMITH; KNIGHT ${ }^{150}$, tendo em vista a etiologia multifatorial das lesões e a necessidade de medir a quantidade de desgaste dentário, propuseram um índice - ÍNDICE DE DESGASTE DENTÁRIO - (TWI - Tooth wear índex), que seria capaz de avaliar todo tipo de destruição não cariosa de acordo com a tabela abaixo, onde V indica a superfície vestibular; L lingual; O, oclusal; I, inicsal; e C, cervical. (Tabela 3). O índice media o desgaste por escores de 0 a 4 de acordo com sua severidade, sendo 0 a ausência de desgaste e 4 representava desgaste severo ou exposição pulpar.

Tabela 3 - Índice de desgaste dentário - (TWI - Tooth wear índex) proposto por Smith e Knight, em 1984.

\begin{tabular}{|c|c|c|}
\hline Escore & Superfície & Critérios \\
\hline 0 & $\begin{array}{l}\mathrm{V}, \mathrm{L}, \mathrm{O} \text { ou I } \\
\mathrm{C}\end{array}$ & $\begin{array}{l}\text { Nenhuma perda nas características do esmalte. } \\
\text { Sem perda de contornos }\end{array}$ \\
\hline 1 & $\begin{array}{l}\mathrm{V}, \mathrm{L}, \mathrm{O} \text { ou I } \\
\mathrm{C}\end{array}$ & $\begin{array}{l}\text { Perda nas características da superfície do esmalte. } \\
\text { Mínima perda de contorno }\end{array}$ \\
\hline 2 & $\begin{array}{l}\text { V, L, O } \\
\text { I } \\
\text { C }\end{array}$ & $\begin{array}{l}\text { Perda de esmalte com exposição de dentina em < de 1/3 da superfície. } \\
\text { Perda de esmalte com exposição e dentina } \\
\text { Defeito com menos de } 1 \mathrm{~mm} \text { de profundidade }\end{array}$ \\
\hline 3 & $\begin{array}{l}\mathrm{V}, \mathrm{L}, \mathrm{O} \\
\mathrm{I}\end{array}$ & $\begin{array}{l}\text { Perda de esmalte com exposição de dentina em > 1/3 da superfície. } \\
\text { Perda de esmalte e perda substancial de dentina, porém sem exposição } \\
\text { pulpar ou presença de dentina secundária } \\
\text { Defeito com 1-2 } \mathrm{mm} \text { de profundidade }\end{array}$ \\
\hline 4 & V, L, O & $\begin{array}{l}\text { Perda completa de esmalte, ou exposição pulpar ou presença de } \\
\text { dentina secundária. } \\
\text { Exposição pulpar ou exposição de dentina secundária } \\
\text { Defeito com de } 2 \mathrm{~mm} \text { de profundidade, ou exposição pulpar ou } \\
\text { exposição de dentina secundária. }\end{array}$ \\
\hline
\end{tabular}


O'BRIEN ${ }^{120}, 1994$ utilizou um índice (Tabela 4) para medir a erosão dentária em um estudo epidemiológico realizado no Reino Unido, onde avaliava a profundidade das lesões e a área de superfície dental envolvida. Utilizou escores que vão de 0 a 3 para codificar as superfícies vestibular, lingual e incisal:oclusal, estabeleceu critérios que envolvem somente esmalte, esmalte/dentina e esmalte/dentina/polpa envolvidos em diferentes graus e acrescentando a extensão de área envolvida pela lesão.

Tabela 4 - Índice de erosão dental proposto por O’Brien, em 1994.

\begin{tabular}{|c|l|}
\hline \multicolumn{1}{|c|}{ Código } & \multicolumn{1}{c|}{ Critérios } \\
\hline Profundidade & \\
\hline $\mathbf{0}$ & Normal \\
\hline $\mathbf{1}$ & Perda da caracterização da superfície do esmalte somente \\
\hline $\mathbf{2}$ & Esmalte e dentina, perda de esmalte expondo dentina \\
\hline $\mathbf{3}$ & $\begin{array}{l}\text { Esmalte até polpa, perda de esmalte e dentina resultando em exposição } \\
\text { pulpar }\end{array}$ \\
\hline $\mathbf{9}$ & Não avaliada \\
\hline Área & \\
\hline $\mathbf{0}$ & Normal \\
\hline $\mathbf{1}$ & Menos de $1 / 3$ da superfície envolvida \\
\hline $\mathbf{2}$ & Entre $1 / 3$ a $2 / 3$ da superfície envolvida \\
\hline $\mathbf{3}$ & Mais de $2 / 3$ da superfície envolvida \\
\hline $\mathbf{9}$ & Não avaliada \\
\hline
\end{tabular}

O'Sullivan ${ }^{121}, 2000$ propôs um índice para erosão dentária (Tabela 5), o qual está apresentado na tabela abaixo. O índice utiliza letras para descrever as superfícies envolvidas na erosão, número para relatar o grau de severidade e +oupara descrever a extensão do envolvimento da superfície. Embora seja detalhado o exame, a reprodutibilidade reduz muito, visto que existe grande dificuldade de coerência no uso dos códigos durante o exame. 
Tabela 5 - Índice de erosão dental proposto por O'Sullivan, 2000.

\begin{tabular}{|c|c|}
\hline Código & Área de erosão \\
\hline A & Vestibular somente \\
\hline B & Palatal ou lingual somente \\
\hline C & Incisal ou oclusal somente \\
\hline D & Vestibular e incisal/oclusal \\
\hline E & Palatal e incisal/oclusal \\
\hline $\mathbf{F}$ & Várias faces $(\mathrm{V}, \mathrm{I}, \mathrm{P} / \mathrm{L}, \mathrm{O})$ \\
\hline Código & Grau de severidade \\
\hline 0 & Esmalte normal \\
\hline 1 & Esmalte alterado mas sem perda de contorno \\
\hline 2 & Esmalte alterado com perda de contorno \\
\hline 3 & $\begin{array}{l}\text { Perda de esmalte com exposição de dentina (junção amelodentinária visível } \\
\text { - JAD) }\end{array}$ \\
\hline 4 & Perda de esmalte e dentina além da (junção amelodentinária visível - JAD) \\
\hline 5 & Perda de esmalte e dentina com exposição pulpar \\
\hline 9 & Não analisado \\
\hline \multicolumn{2}{|l|}{$\begin{array}{l}\text { Área da } \\
\text { superfície }\end{array}$} \\
\hline- & Menos da metade da área afetada \\
\hline+ & Mais da metade da área afetada \\
\hline
\end{tabular}

Sales-Peres et al. ${ }^{138}, 2005$ propõem um índice de desgaste dentário IDD (Tabela 6), para ser aplicado em estudo epidemiológicos. O índice adota escore de 0 a 4 para dentes permanentes e de a até e para dentes decíduos, inclui o critério de não avaliado para dentes permanentes (código 9) e (código -) para dentes decíduos, distribui a análise por estrutura dentária (esmalte, dentina e polpa) e respectivas superfícies (vestibular, lingual e incisal/oclusal), sendo incluídos todos os dentes no exame. Segundo os autores, a justificativa para a adoção do referido índice é o aumento na reprodutibilidade quando comparado aos demais índices estudados. 
Tabela 6 - Índice de desgaste dentário proposto por Sales Peres et al., em 2005.

\begin{tabular}{|c|c|c|c|}
\hline \multicolumn{2}{|c|}{ Escore } & \multirow[t]{2}{*}{ Critério } & \multirow[t]{2}{*}{ Descrição } \\
\hline Dente Dec. & Dente Per. & & \\
\hline a & 0 & $\begin{array}{l}\text { Normal: sem evidência de } \\
\text { desgaste }\end{array}$ & $\begin{array}{l}\text { Nenhuma perda nas características do } \\
\text { esmalte }\end{array}$ \\
\hline b & 1 & $\begin{array}{l}\text { Incipiente: desgaste em } \\
\text { esmalte }\end{array}$ & $\begin{array}{l}\text { Perda nas características da superfície } \\
\text { do esmalte, sem envolvimento da } \\
\text { dentina }\end{array}$ \\
\hline C & 2 & $\begin{array}{l}\text { Moderado: desgaste } \\
\text { envolvendo dentina }\end{array}$ & $\begin{array}{l}\text { Perda de esmalte com exposição da } \\
\text { dentina }\end{array}$ \\
\hline$d$ & 3 & $\begin{array}{l}\text { Severo: desgaste se } \\
\text { estendendo até a polpa } \\
\text { ou dentina secundária }\end{array}$ & $\begin{array}{l}\text { Extensa perda de esmalte e de dentina } \\
\text { com exposição da polpa ou dentina } \\
\text { secundária }\end{array}$ \\
\hline e & 4 & $\begin{array}{l}\text { Restauração: restaurado } \\
\text { por causa de desgaste }\end{array}$ & $\begin{array}{l}\text { O dente recebeu tratamento restaurador } \\
\text { devido ao desgaste }\end{array}$ \\
\hline- & 9 & $\begin{array}{l}\text { Sem registro: não } \\
\text { avaliado }\end{array}$ & $\begin{array}{l}\text { Cáries extensas, restauração grande, } \\
\text { dente com fratura ou dente ausente, } \\
\text { aparelho ortodôntico, hipoplasias. }\end{array}$ \\
\hline
\end{tabular}

\subsubsection{Estudos de prevalência do desgaste dentário em pacientes com transtornos alimentares}

A primeira publicação existente na literatura a respeito de erosão dentária associada a distúrbios gastrointestinais foi feita por BARGEN; AUSTIN ${ }^{24}, 1937$, onde descreveram o caso clínico de uma paciente que apresentava perda de esmalte dentário na superfície lingual dos dentes anteriores superiores e inferiores. Os incisivos apresentavam-se diminuídos com margens incisais agudas, e as restaurações de amálgama apresentavam-se salientes como ilhas de metal. O relato da paciente era de que vomitava diariamente logo após as refeições.

HELLSTRÖM $^{78}, 1977$, examinou 39 pacientes com anorexia e bulimia nervosa, entre os quais 38 eram do sexo feminino, sendo que 27 , com histórico de 
vômitos intensos, apresentavam severa erosões dentárias na superfície lingual e oclusal dos dentes posteriores e anteriores.

ROBERTS; LI $^{134}, 1987$, realizaram um estudo em 17 pacientes com AN e 30 pacientes com $\mathrm{BN}$, verificaram uma diferença na incidência de erosão dentária entre os dois grupos, sendo maior nos indivíduos com AN (60\%) do que naqueles pacientes com BN (20\%). Esse fato pode estar relacionado aos cuidados com a higiene bucal após episódios de vômito, relatados pelos pacientes com BN. Já nos casos de pacientes com AN estavam relacionados com depressão e, provavelmente por isso, não havia preocupação e interesse em manter cuidados específicos com a higiene bucal.

SPIGSET ${ }^{154}$, 1991, avaliou as manifestações de saúde bucais de 34 pacientes do gênero feminino com BN e observou que 68\% apresentavam hiperestesia dentinária e 6 \% apresentavam fratura dentária em função da erosão.

RYTÖMAA, et al. ${ }^{137}$, 1998, realizaram um estudo com 35 pacientes com BN e também verificaram que a ocorrência de erosão dentária nesses casos é bastante comum. Foi observada uma perda de esmalte dentário mais freqüentemente em incisivos superiores e constatada que metade dos pacientes examinados não conhecia o efeito da doença sobre seus dentes.

SMITH; BARTLETT; ROBB ${ }^{149}$, 1997, realizaram um exame detalhado de pacientes com quadros odontológicos típicos de perimólise, lesões lisas com contornos arredondados, sem sinais de pigmentação, predominantemente nas superfícies palatinas dos dentes anteriores superiores, linguais dos posteriores, encurtamento dos incisivos superiores, restaurações salientes, hiperestesia dentinária e a ocorrência de vômitos em função de problemas no aparelho digestivo, como úlceras, gastrites, hérnia de hiato, e até mesmo, alcoolismo crônico.

Segundo SHIPLEY; TAYLOR; MITCHELL ${ }^{145}$, 2005, relataram que pacientes acometidos pela bulimia nervosa, 90\% destes irão apresentar erosão dentária. Devido à destruição causada pelo suco gástrico, os sinais podem aparecer na dentição desses pacientes em poucos meses. Clinicamente a aparência mais comum é a erosão severa na face lingual dos incisivos e caninos superiores. A superfície oclusal também apresenta facetas de desgaste e altamente polida, num 
processo de associação de desgaste químico e mecânico. O ácido gástrico parece não afetar os dentes inferiores, devido à proteção da língua. 
3 PROPOSIÇÃO 



\section{PROPOSIÇÃO}

A proposta deste estudo foi avaliar a prevalência e a severidade de desgaste dentário em pacientes portadores de transtornos alimentares (TAS), atendidos pela equipe multiprofissional do GRATA (Grupo de Assistência aos Transtornos Alimentares) do Hospital das Clínicas da Faculdade de Medicina de Ribeirão Preto - USP (HCFMRP - USP). 

4 MATERIAIS E METODOS 



\section{MATERIAL E MÉTODOS}

\subsection{ASPECTOS ÉTICOS}

Este projeto foi submetido à avaliação pelo Comitê de Ética em Pesquisa (CEP) do Hospital das Clínicas da Faculdade de Medicina de Ribeirão Preto (HCFMRP/USP), sob responsabilidade da autora Juliana Julianelli de Araújo, com a orientação do Prof. Dr. José Roberto de Magalhães Bastos, Professor Titular do Departamento de Odontopediatria, Ortodontia e Saúde Coletiva da Faculdade de Odontologia de Bauru - USP, estando ciente o Prof. Dr. José Ernesto dos Santos, Professor Associado do Departamento de Clínica Médica da Faculdade de Medicina de Ribeirão-Preto - USP, da realização de tal projeto nas dependências do Departamento de Clínica Médica do Hospital das Clínicas da Faculdade de Medicina de Ribeirão - Preto - USP, onde se encontra o GRATA, de acordo com a resolução no 196/96 do Conselho Nacional do Ministério da Saúde, sob o protocolo no 28.32/2007 (Anexo A).

Houve desde o início desse estudo, o compromisso em respeitar os aspectos éticos envolvidos, assegurando assim, a impossibilidade de identificação dos sujeitos participantes dessa pesquisa. As informações obtidas por meio de entrevistas foram mantidas em sigilo, somente para realização deste estudo. A participação dos sujeitos foi voluntária, com total liberdade para os mesmos desistirem em qualquer momento da colaboração com esse estudo, sem nenhum prejuízo ou punição. Este estudo não ofereceu risco ou dano significativo ao indivíduo participante. Os resultados obtidos neste estudo deverão ser publicados e apresentados em eventos científicos. 


\subsection{EQUIPE MULTIPROFISSIONAL}

Em 1982, foi criado o Ambulatório de Distúrbios da Conduta Alimentar e do Peso do HCFMRP-USP (Hospital das Clínicas da Faculdade de Medicina de Ribeirão Preto-USP) por iniciativa do médico psiquiatra assistente do serviço de nutrologia, que sentia a necessidade de oferecer recursos terapêuticos especializando o atendimento, a fim de receber esses casos. Contudo, o serviço cresceu devido à demanda de pacientes para este tratamento. Atualmente, este ambulatório foi nomeado como Grupo de Assistência aos Transtornos Alimentares (GRATA), no qual conta com uma equipe multiprofissional composta por nutricionistas, médicos nutrólogos, psiquiatra, psicólogos e atualmente uma cirurgiãdentista, que atendem os pacientes com TAs, dentro de um modelo de atenção assistencial. Nas internações hospitalares participam também o clínico geral, o enfermeiro e o terapeuta ocupacional.

\subsection{COMPOSIÇÃO DA AMOSTRA}

A população alvo deste estudo foi composta por 30 pacientes portadoras de TAs, na faixa etária de 13 a 44 anos, todas do gênero feminino, devidamente atendidas no GRATA (Grupo de Assistência aos Transtornos Alimentares do HRFMRP/USP); sendo que 8 apresentavam AN tipo restritiva; 9 pacientes com AN tipo purgativo; 12 pacientes com BN e destas 1 apresentava-se com Síndrome de Morse hermafroditismo e 1 paciente com TCAP.

Os critérios para inclusão dos pacientes na amostra foram:

$>$ autorização por meio da assinatura do (TCLE) termo de consentimento livre e esclarecido (Anexo C), após a leitura da Carta de Informação (Anexo B);

$>$ pacientes em tratamento, sem internação no GRATA do HCFMRP-USP. 
A dificuldade encontrada durante este projeto foi à limitação do tempo no preenchimento do questionário e realização do exame clínico, visto que por vezes a pesquisa iniciou-se após o último atendimento com os demais profissionais da equipe do GRATA.

\subsection{DELINEAMENTO DO ESTUDO}

O estudo foi composto pelas seguintes etapas: a) calibração do examinador; b) apresentação da cirurgiã-dentista ao GRATA (Grupo de Assistência aos Transtornos Alimentares); c) inserção do cirurgião-dentista ao grupo de pacientes; d) aplicação de questionário contendo perguntas objetivas; e) exame clínico;

\subsubsection{Calibração do examinador para avaliar desgaste dentário}

O processo de calibração para avaliação de desgaste dentário foi conduzido por um examinador padrão e experiente em levantamentos epidemiológicos, sendo que, as atividades teórico-práticas envolveram exercícios de treinamento em área de campo e calibração, compreenderam um total de 6 períodos de 4 horas de trabalho. No primeiro período de treinamento foi administrada aula teórica, no qual se buscou a padronização inicial quanto aos códigos, critérios e condutas de exames adotados no estudo. Nesta aula foram solucionadas dúvidas e exposição visual de casos clínicos em sala de aula com discussões sobre os tipos de desgaste dentário que foram observados na área de campo. A calibração propriamente dita ocorreu em 5 períodos, no qual foram selecionadas crianças de diferentes faixas etárias, devidamente matriculadas na Casa do Garoto, que é uma Instituição vinculada pela Faculdade de Odontologia de Bauru - FOB/USP. Foram examinadas crianças sem que os casos fossem discutidos durante o atendimento. Após o término do exame, foi aberta uma discussão geral dos casos, com a presença do examinador padrão, certificando-se que a cirurgiã-dentista estava familiarizada com os códigos. 


\subsubsection{Apresentação da cirurgiã-dentista ao GRATA e inserção do cirurgião- dentista ao grupo de pacientes portadores de transtornos alimentares}

Em primeiro momento, o profissional responsável pelo ambulatório de transtornos alimentares apresentou a cirurgiã-dentista aos membros da equipe multiprofissional do GRATA, que conta com médico clínico geral, nutrólogo, psiquiatra, psicólogos, nutricionistas. Em seguida a cirurgiã-dentista foi inserida no grupo de pacientes portadores de transtornos alimentares, destacando a importância da interação do cirurgião-dentista na equipe multiprofissional, buscando contribuir na prevenção e tratamento de alterações na boca, proporcionando benefícios à saúde bucal e geral desses pacientes.

\subsubsection{Aplicação do questionário}

Inicialmente foi aplicado um questionário estruturado dividido em duas partes. O questionário foi aplicado pela pesquisadora responsável que pôde sanar qualquer dúvida dos sujeitos da pesquisa durante o preenchimento das respostas do questionário.

A primeira parte do questionário (Apêndice A) constou de perguntas relacionadas à identificação dos pacientes, dados cadastrais e suas variáveis sócioeconômicas. Neste momento foi apresentado o TCLE, juntamente com a carta de informação, explicando o propósito deste estudo e a livre escolha do sujeito em participar da pesquisa.

A segunda parte do questionário (Apêndice B) foi composta por perguntas estruturadas, para a detecção de hábitos presentes na rotina diária dos pacientes acometidos com transtornos alimentares; abrangendo questões sobre cuidados com higiene bucal, hábitos bucais e alimentares, a fim de detectar os riscos de desgaste dentário. As respostas foram assinaladas por um " $X$ ". 


\subsubsection{Exame clínico}

Todos os pacientes foram avaliados por um único examinador devidamente calibrado, observando-se a presença de diferentes graus de desgaste dentário.

Para realização dos exames foi utilizado sondas CPI (também conhecidas com "sonda da OMS"); espelhos bucais planos $\mathrm{n}^{\circ} 5$, previamente esterilizados conforme as normas de biossegurança do Ministério da Saúde (OMS ${ }^{123}$, 1999), dispondo de instrumentos em número suficiente para realização dos exames. Uma vez utilizados em pacotes individuais foram recolhidos e somente reutilizados após a esterilização em autoclave. Os demais materiais utilizados para o procedimento do exame clínico foram: espátulas de madeira; gaze estéril com o intuito de secar a superfície dentária; para melhor visualização foi utilizada uma fonte de luz artificial. Material de biossegurança como: máscara, touca, luvas de procedimento descartáveis, guardanapo de papel. Prancheta de madeira, lápis e borracha para o preenchimento do índice de desgaste dentário (Apêndice C).

Devido à ausência de um consultório odontológico no local e a dificuldade de um espaço físico adequado para realização do exame clínico, foi necessária a adaptação de um ambiente. Em uma sala adaptada foi realizada a montagem da mesa clínica (Figura 20), utilizou-se uma cadeira (Figura 21) onde os pacientes foram avaliados e uma fonte de luz artificial (Figura 22) para facilitar na visualização.

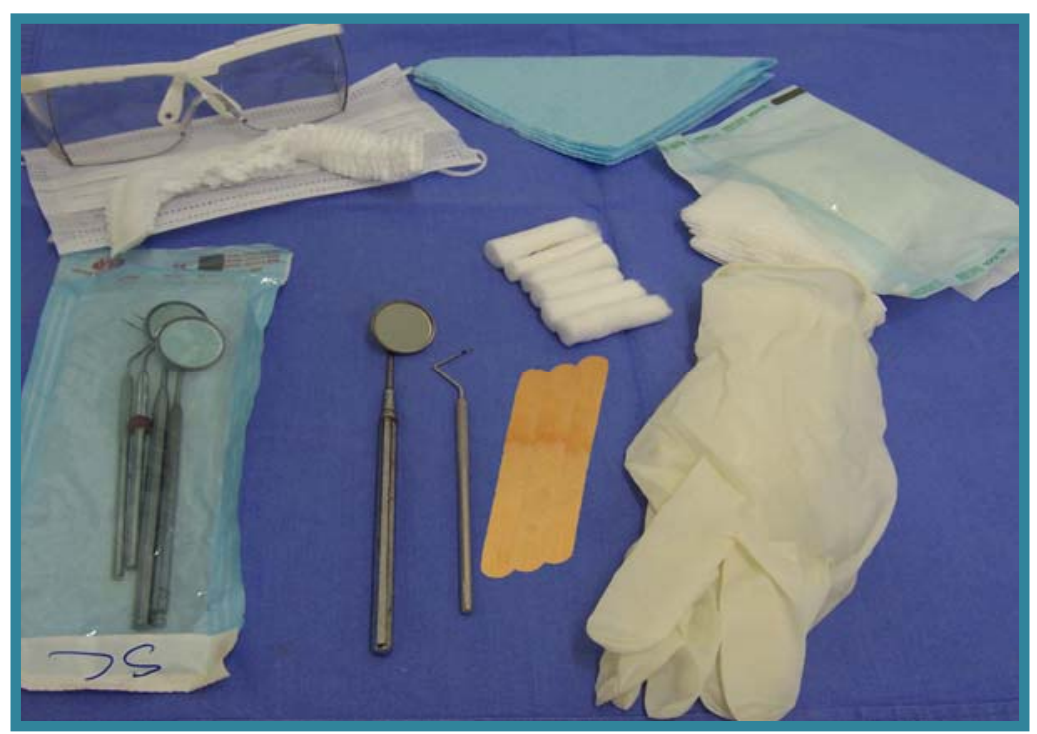

Figura 20 - Mesa clínica 



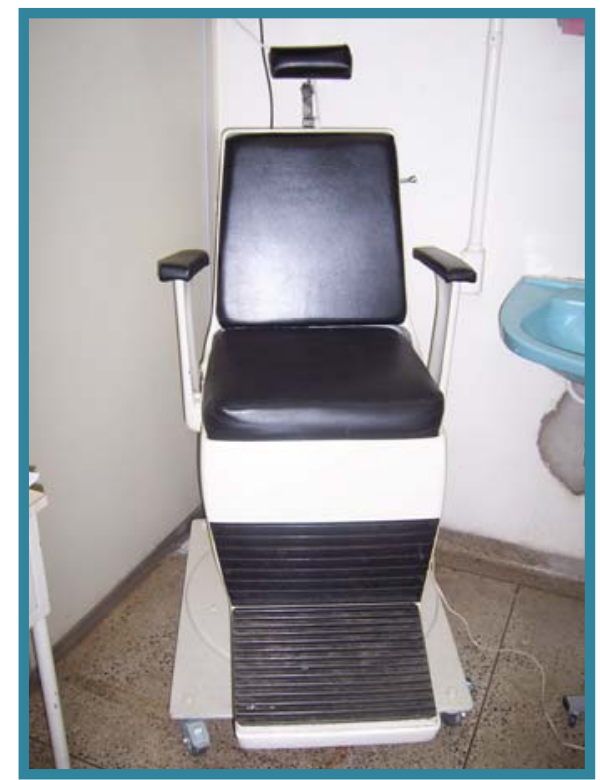

Figura 21 - Cadeira

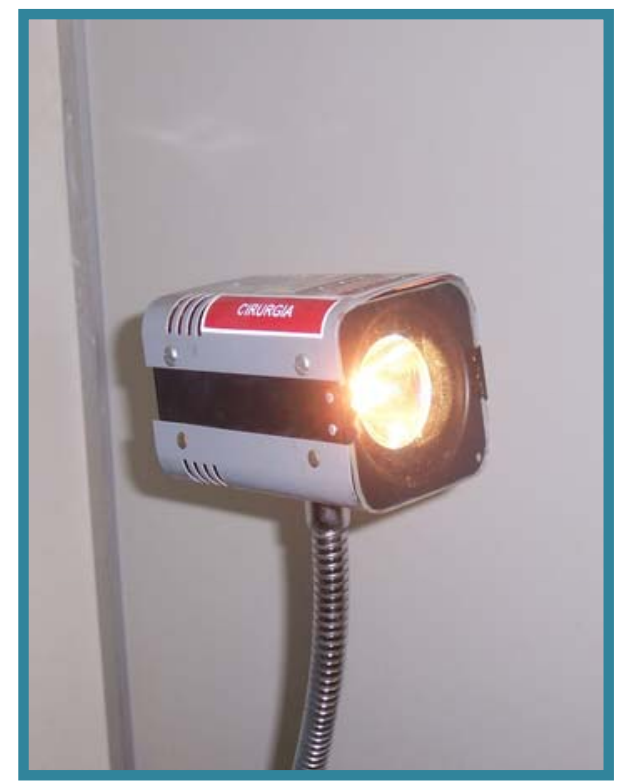

Figura 22 - Fonte de Luz artificial

\subsubsection{Códigos e critérios utilizados}

Para avaliação do desgaste dentário nos pacientes com transtornos alimentares foi adotado o índice proposto por SMITH; KNIGHT ${ }^{150}, 1984$, e adaptado por SALES PERES et al. ${ }^{138}, 2005$ (Figura 23). O exame foi iniciado pelo terceiro molar até o incisivo central do hemiarco superior direito (do 18 ao 11), passando em seguida ao incisivo central do hemiarco superior esquerdo e indo até o terceiro molar (do 21 ao 28), indo para o hemiarco inferior esquerdo (31 ao 38) e, finalmente, concluindo com o hemiarco inferior direito (do 41 ao 48).

O índice de Desgaste Dentário (TWI - Tooth Wear Índex), proposto por SMITH; KNIGHT ${ }^{150}, 1984$, porém, foi o que se tornou um guia e, simultaneamente, um método de monitoramento de mudanças progressivas do desgaste em um paciente, ao longo do tempo, passando a ser adotado para a grande maioria dos estudos relacionados ao desgaste dentário. A adoção desse índice em estudos epidemiológicos foi dificultada, visto que não contemplava o critério não avaliado e subdividia a dentina em diferentes graus de extensão, o que reduzia acentuadamente a reprodutibilidade. 

O índice adotado foi o IDD- índice de desgaste dentário, proposto por SALES PERES et al. ${ }^{138}$, 2005, o qual permite avaliar as superfícies vestibulares, linguais e oclusais/incisais, individualmente. Propõe avaliar todos os dentes e adotar escores que vão de 0 a 4, por meio de critérios que envolvem somente esmalte, esmalte/dentina, esmalte/dentina/polpa e superfície restaurada devido ao desgaste. Cada superfície do dente susceptível ao desgaste dentário é examinada visualmente.

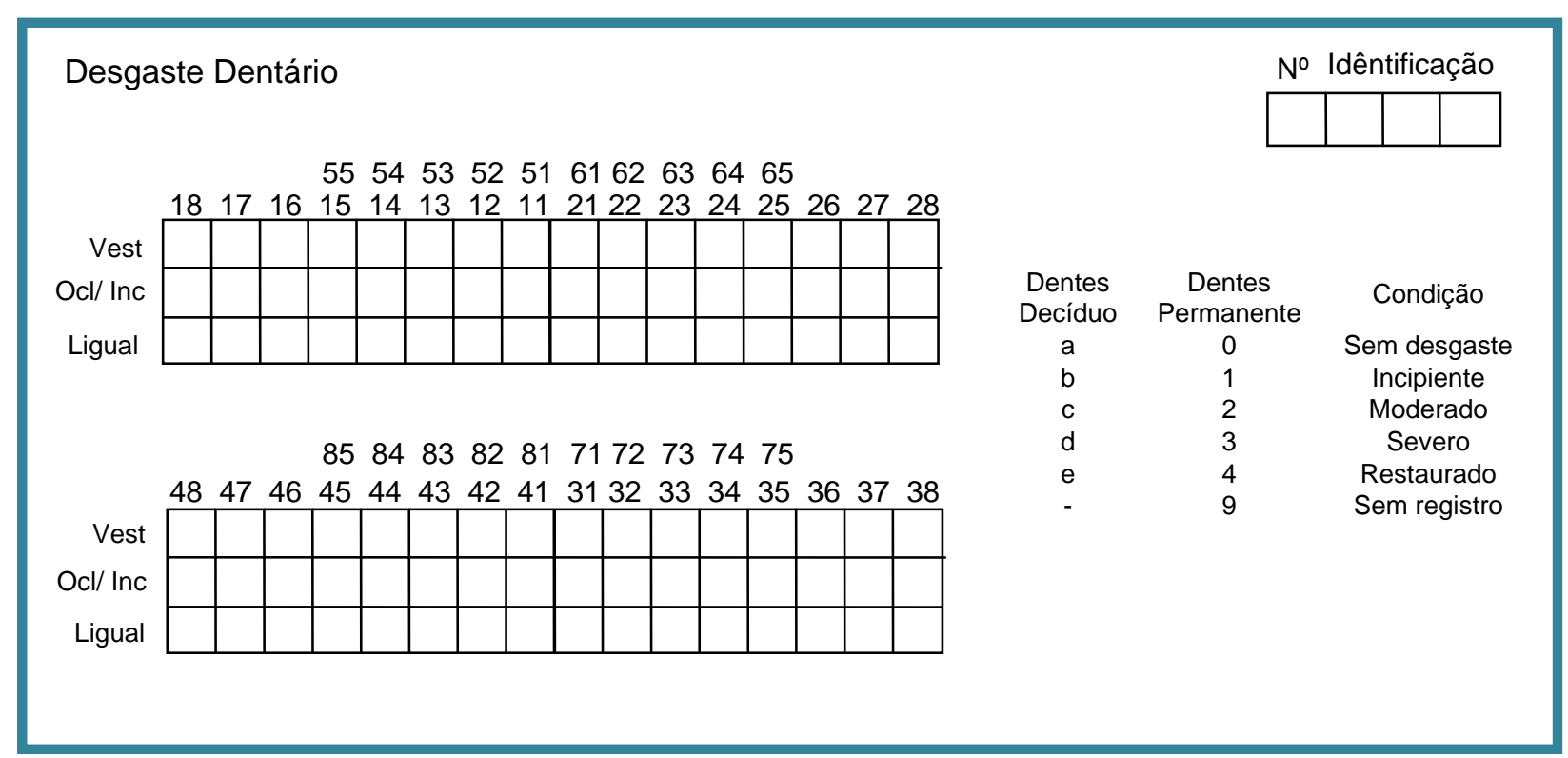

Figura 23 - Índice adaptado para Desgaste Dentário (IDD).

De acordo com o Índice Desgaste Dentário-IDD, as condições de desgaste dentário são:

0-Sem Desgaste: Superfície dentária sem desgaste dentário;

1-Incipiente: Superfície dentária a qual apresenta desgaste dentário envolvendo apenas o esmalte.

2-Moderada: Superfície dentária a qual apresenta desgaste dentário envolvendo esmalte e dentina.

3-Severa: Superfície dentária a qual apresenta desgaste dentário com comprometimento pulpar ou envolvimento de dentina secundária.

4-Restaurada: Superfície dentária encontra-se restaurada devido ao desgaste dentário; 
9-Sem Registro: Quando por algum motivo, como, banda ortodôntica não é possível examinar a superfície dentária.

\subsubsection{Análise estatística}

Os dados foram digitados em planilha Excel e procedeu-se à análise estatística por meio de freqüências absolutas e relativas, apresentadas em tabelas e gráficos. Adotou-se o teste de Mann Whitney para amostras independentes, sendo adotado um nível de significância de 5\%. 
5 RESULTADOS 


\section{RESULTADOS}

\subsection{CARACTERIZAÇÃO DA AMOSTRA}

A faixa etária dos pacientes com transtornos alimentares variou entre $13 \mathrm{e}$ 44 anos, com uma média de 26,8 e desvio padrão de 8,2 , no qual todos são do gênero feminino, dispostas na tabela 7. O percentual do tipo de transtornos alimentares encontra-se na tabela 8.

Tabela 7 - Percentual de pacientes com transtornos alimentares por faixa etária

\begin{tabular}{|c|c|c|}
\hline Idade & $\mathbf{n}$ & $\%$ \\
\hline 13 a 18 anos & 5 & 16,67 \\
\hline 19 a 24 anos & 8 & 26,67 \\
\hline 25 a 30 anos & 7 & 23,33 \\
\hline 31 a 36 anos & 7 & 23,33 \\
\hline 37 a 44 anos & 3 & 10,00 \\
\hline TOTAL & $\mathbf{3 0}$ & 100,00 \\
\hline
\end{tabular}

Tabela 8 - Percentual do tipo de transtorno alimentar

\begin{tabular}{|c|c|c|}
\hline Transtornos Alimentares & $\mathbf{n}$ & $\%$ \\
\hline Anorexia nervosa - Restritiva & 8 & 26,67 \\
\hline Anorexia nervosa - Purgativa & 9 & 30,00 \\
\hline Bulimia Nervosa & 12 & 40,00 \\
\hline $\begin{array}{c}\text { Transtorno de compulsão alimentar } \\
\text { periódica }\end{array}$ & 1 & 3,33 \\
\hline TOTAL & $\mathbf{3 0}$ & $\mathbf{1 0 0 , 0 0}$ \\
\hline
\end{tabular}


Das $30(100 \%)$ pacientes portadoras de TAs, encontramos: $8(26,67 \%)$ apresentavam AN tipo restritiva; 9 (30\%) pacientes com AN tipo purgativo; 12 (40\%) pacientes com BN e destas 1 apresentava-se com Síndrome de Morse hermafroditismo e $1(3,33 \%)$ paciente com TCAP.

Com relação à avaliação do nível de escolaridade das pacientes, constatou-se que $50 \%$ responderam ter curso superior conforme demonstra a tabela 9.

Tabela 9 - Número de pacientes com transtornos alimentares por nível de escolaridade

\begin{tabular}{|c|c|c|}
\hline Nível de escolaridade & $\mathbf{n}$ & $\%$ \\
\hline $1^{\circ}$ Grau completo & 6 & 20,00 \\
\hline $2^{\circ}$ Grau completo & 9 & 30,00 \\
\hline Superior & 15 & 50,00 \\
\hline TOTAL & 30 & 100,00 \\
\hline
\end{tabular}

Com respeito à ocupação, observamos que 33,33 \% são estudantes, correspondendo a 10 pacientes; $16,67 \%$ são do lar de acordo com a tabela 10. 
Tabela 10 - Percentual de pacientes em relação à ocupação

\begin{tabular}{|l|c|c|}
\hline \multicolumn{1}{|c|}{ Ocupação } & $\mathbf{n}$ & $\%$ \\
\hline Biomédica & 1 & 3,33 \\
\hline Promotora de vendas & 1 & 3,33 \\
\hline Balconista & 1 & 3,33 \\
\hline Cantora & 1 & 3,33 \\
\hline Professora & 1 & 3,33 \\
\hline Enfermeira & 1 & 3,33 \\
\hline Técnico de enfermagem & 1 & 3,33 \\
\hline Auxiliar de enfermagem & 1 & 3,33 \\
\hline Decoradora & 1 & 3,33 \\
\hline Secretária & 1 & 3,33 \\
\hline Do lar & 5 & 16,67 \\
\hline Babá & 2 & 6,67 \\
\hline Auxiliar administrativo & 2 & 6,67 \\
\hline Estudante & 10 & 33,33 \\
\hline & 30 & 100,00 \\
\hline
\end{tabular}

Quanto à renda familiar, observaram-se resultados tais como: 33,3\% dos pacientes, 10 classificaram-se na faixa de renda familiar de 760,00 correspondentes a dois salários mínimos (tabela 11).

Tabela 11 - Percentual de pacientes em relação à renda familiar

\begin{tabular}{|c|c|c|}
\hline Renda Familiar & $\mathbf{n}$ & $\%$ \\
\hline 380,00 & 4 & 13,33 \\
\hline 760,00 & 10 & 33,33 \\
\hline $1.140,00$ & 8 & 26,67 \\
\hline $1.520,00$ & 4 & 13,33 \\
\hline $2.280,00$ & 4 & 13,33 \\
\hline TOTAL & 30 & 100,00 \\
\hline
\end{tabular}


A procedência dos pacientes em sua maioria são de regiões fora do município de Ribeirão Preto - SP, e preferem se deslocar até o Hospital das Clínicas, por ser mais apropriado e privado (53,4\%). Foi observado que, $36,6 \%$ da amostra residem no município de Ribeirão Preto-SP e somente $10 \%$ são procedentes de regiões fora do estado de São Paulo (tabela 12).

Tabela 12 - Porcentagem de pacientes em relação à procedência.

\begin{tabular}{|l|c|c|}
\hline \multicolumn{1}{|c|}{ Procedência } & $\mathbf{n}$ & $\%$ \\
\hline Batatais - SP & 1 & 3,33 \\
\hline Brodowski -SP & 1 & 3,33 \\
\hline Canapólis - MG & 1 & 3,33 \\
\hline Dumont & 1 & 3,33 \\
\hline Franca & 4 & 13,33 \\
\hline Orlândia & 1 & 3,33 \\
\hline Passos - MG & 1 & 3,33 \\
\hline Poço - Fundo & 1 & 3,33 \\
\hline Ribeirão Preto - SP & 11 & 36,67 \\
\hline São Joaquim da Barra - SP & 2 & 6,67 \\
\hline Sertãozinho - SP & 5 & 16,67 \\
\hline Taiúva & 1 & 3,33 \\
\hline
\end{tabular}

\subsection{CONDIÇÕES DE DESGASTE DENTÁRIO}

Todos os pacientes portadores de transtornos alimentares apresentaram algum grau de desgaste dentário. Os resultados de acordo com a severidade acometida por indivíduos encontram-se na figura 24. 


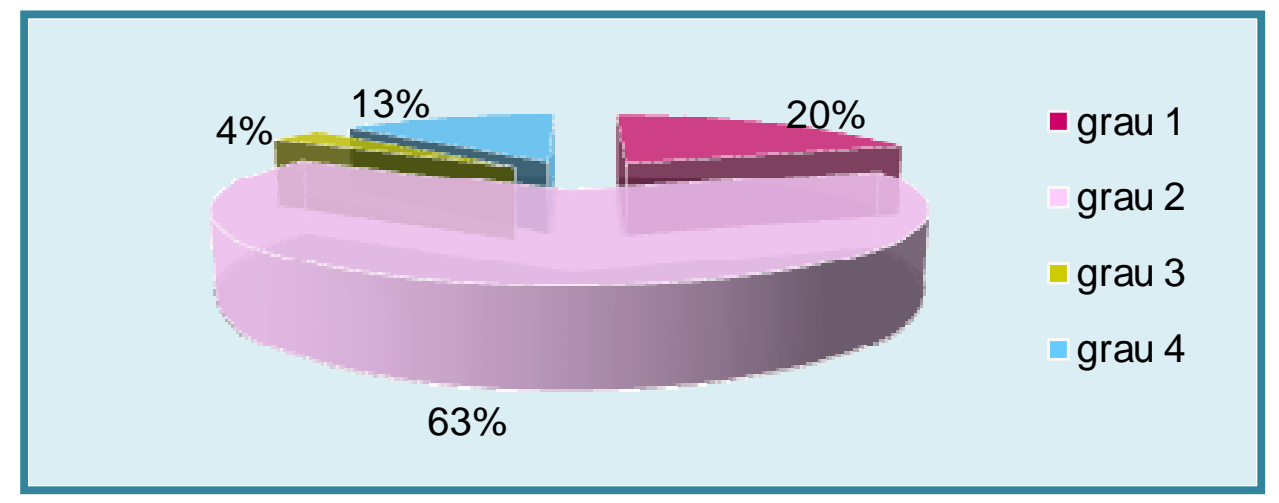

Figura 24 - Percentual de desgaste dentário acometidos por indivíduos em pacientes com transtornos alimentares

A prevalência de desgaste dentário em pacientes com BN foi de $75 \%$ $(n=9)$, acometendo somente dentina de acordo com a figura 25.

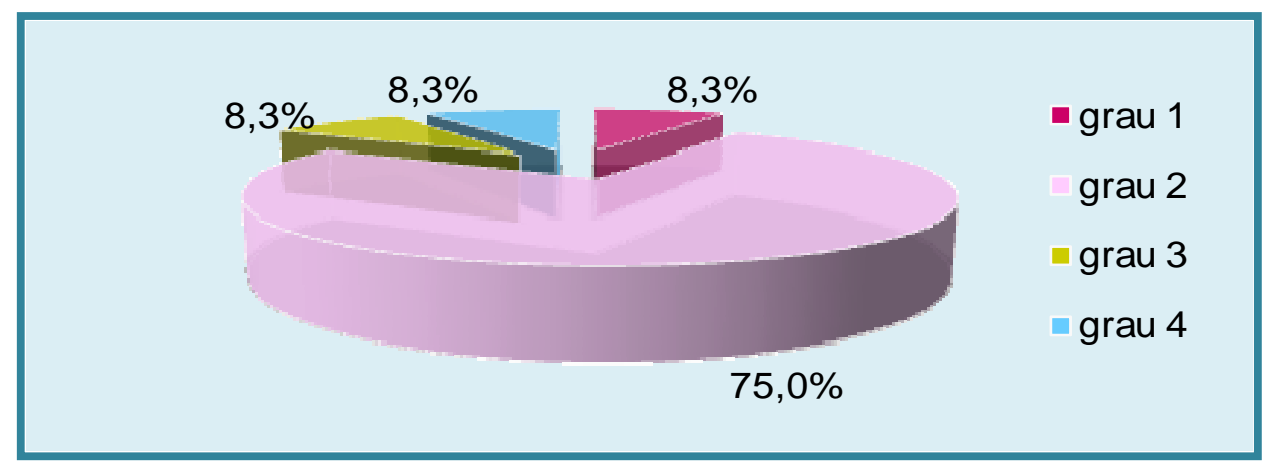

Figura 25 - Percentual de pacientes com bulimia nervosa em relação à severidade do desgaste dentário.

Das oito pacientes com AN-R, foi observado $50 \%(n=4)$ de desgaste dentário com severidade grau 2. (Figura 26). As pacientes com AN-P apresentou 11,1\% ( $n=1)$ desgaste dentário grau 4, 33,3\% $(n=3)$ de desgaste dentário grau 1 e $55,6 \%(n=5)$ com desgaste dentário grau 2. (Figura 27). 


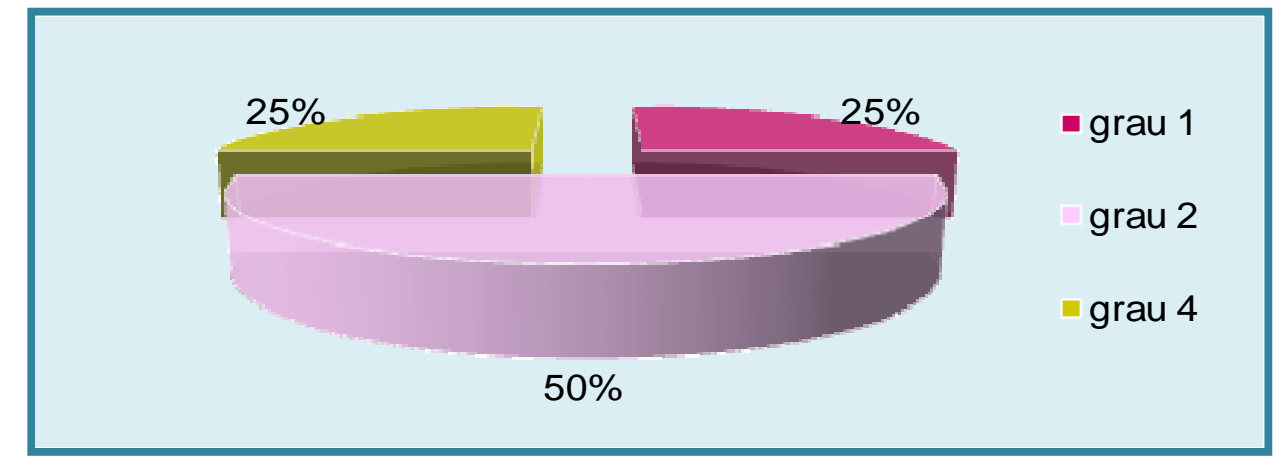

Figura 26 - Percentual de pacientes com anorexia nervosa tipo restritiva em relação à severidade do desgaste dentário.

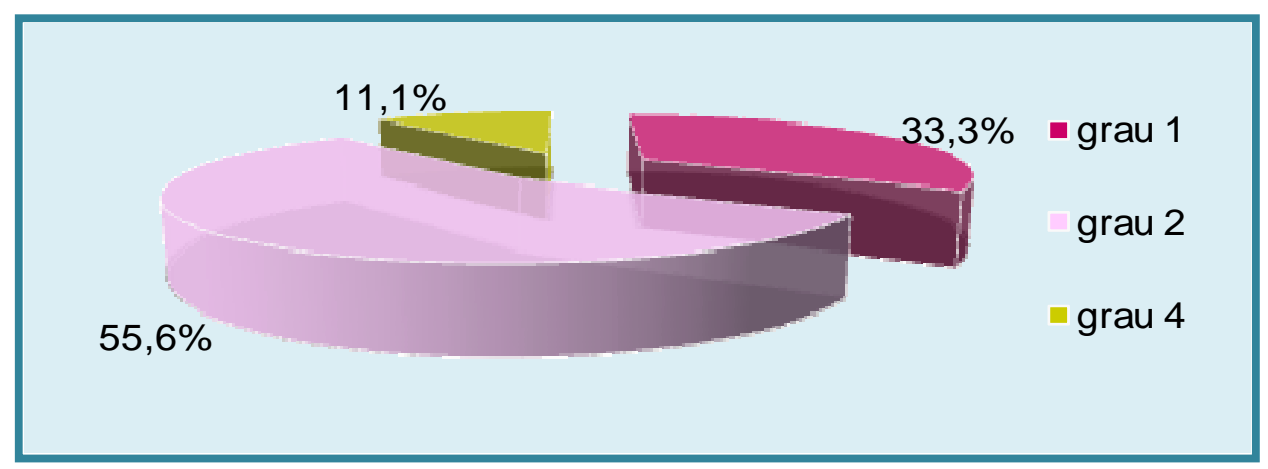

Figura 27 - Percentual de pacientes com anorexia nervosa tipo purgativa em relação à severidade do desgaste dentário.

A superfície dentária mais acometida foi à superfície oclusal/incisal com uma severidade de desgaste dentário em dentina, correspondendo a 66,7\% ( $\mathrm{n=20}$ ). Não foram identificados o grau 3 de desgaste dentário (Figura 28).

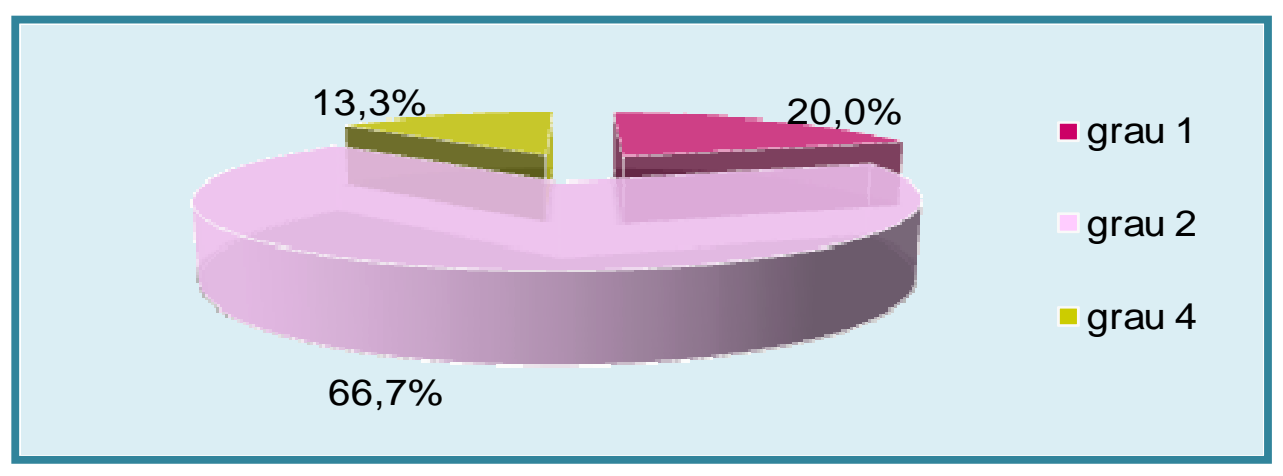

Figura 28 - Percentual de desgaste dentário na superfície oclusal 
Com relação à superfície vestibular observou-se que 76,7\% (n=23) não apresentaram nenhum grau de desgaste dentário e 13,3\% (n=4) apresentaram desgaste dentário grau 4. (Figura 29).

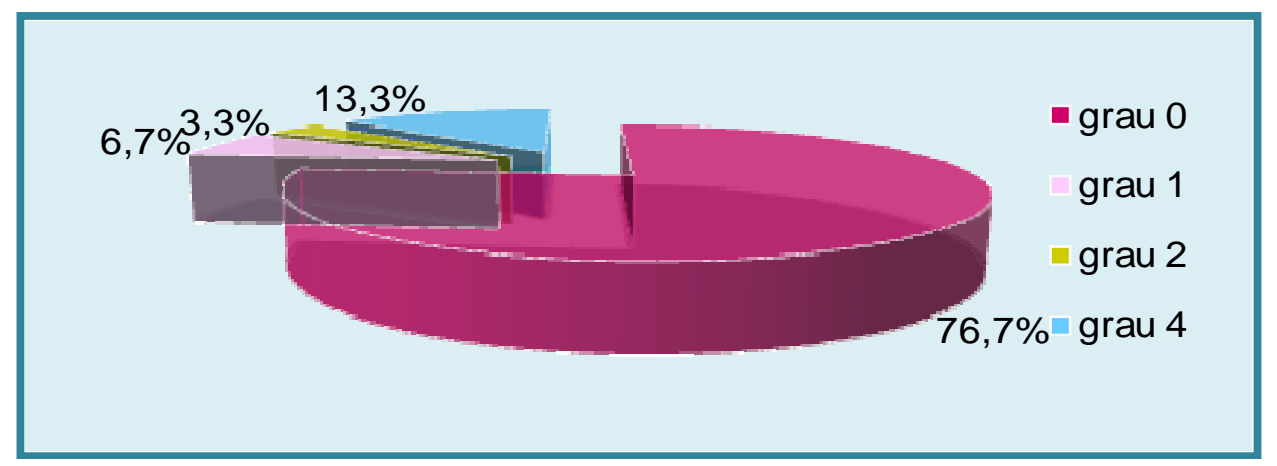

Figura 29 - Percentual de desgaste dentário na superfície vestibular

De acordo com a figura 30, observa-se uma prevalência de desgaste dentário com comprometimento pulpar de 13,4\% (n=4) na superfície lingual.



Figura 30 - Percentual de desgaste dentário na superfície lingual/palatina

As informações sobre hábitos alimentares e condições de saúde bucal foram questionadas.

Todos os pacientes relataram tomar refrigerante, sendo que 66,6\% $(n=20)$ só ingerem coca-cola. Com relação ao hábito de tomar suco, a maioria das entrevistadas prefere os sabores mais cítricos como laranja, limão e tangerina, correspondendo a $63,3 \%(n=19)$. 
Os pacientes que apresentaram desgaste dentário grau 4, do total da amostra (13\%) ingeriam refrigerante coca-cola.

O número de escovações diárias foi avaliado, sendo que a maioria, 33,3\%, respondeu que fazia suas escovações em média 3 vezes ao dia, seguido dos que realizam as escovações 4 vezes ao dia (30\%), 2 vezes ao dia (16,6\%), 1 vez ao dia $(6,7 \%), 2$ vezes ao dia $(6,7 \%)$ e alguns relataram escovar os dentes todas as vezes que comem $(6,7 \%)$.

Questionou-se, em seguida, se o paciente tinha costume de dormir sem escovar os dentes, da amostra $26,7 \%$, responderam que sim, pelo menos 1 vez na semana, enquanto $43,3 \%$ dos entrevistados relataram não deixar de realizar a higiene bucal nenhum dia da semana. (Figura 31).

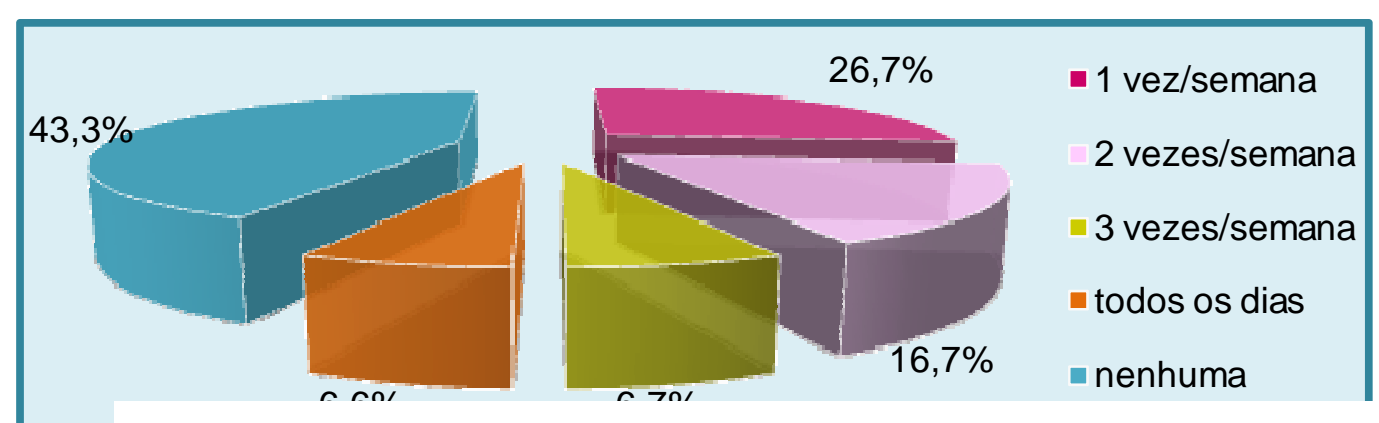

Figura 31 - Percentual de pacientes que deixam de realizar higiene bucal antes de dormir

A preferência dos pacientes sobre o tipo de cerdas das escovas dentais foi questionada, no qual a maioria $73,3 \%(n=22)$ preferia cerdas macias. Já $26,6 \%$ $(n=8)$ referem preferir escovas dentais com cerdas médias.

Em relação ao movimento utilizado para escovar a superfície vestibular dos dentes, ou seja, $50 \%(n=15)$ dos pacientes responderam que costumam utilizar movimentos circulares, enquanto $33,3 \%(n=10)$ realizam o movimento de trás para frente/frente para trás e somente $16,3 \%(n=5)$ utilizam movimentos de cima para baixo/baixo para cima. 
Investigando sobre hábitos bucais, como, ranger os dentes, morder objetos, roer unha, mascar chiclete, morder língua e lábios, a maioria dos pacientes, isto é, $86,6 \%(n=26)$ afirmaram ter um ou mais hábitos bucais e apenas $13,4(n=4)$ relataram não ter nenhum tipo de hábito bucal.

Foram analisados os seguintes fatores associados com os diferentes graus de desgaste dentário: ingestão de coca-cola, guaraná, sprite, fanta; consumo de sucos sabor laranja e limão; ocorrência de refluxo e vômito; presença de hábitos bucais: ranger os dentes, apertar os dentes, morder lábios, roer unha e morder objeto, sendo que não houve diferença significativa $(p>0,05)$ para ocorrência de desgaste dentário na superfície vestibular e lingual. Embora o fator ranger os dentes tenha sido significativo $(p=0,04)$.

Porém, com relação ao desgaste dentário na superfície oclusal, os fatores ranger e apertar os dentes apresentaram significância ( $p=0,02$ e $p=0,01$ respectivamente). 

6 DISCUSSÃO 



\section{DISCUSSÃO}

\subsection{TRANSTORNOS ALIMENTARES}

Os transtornos alimentares tornaram-se, nos últimos 15 anos, alvo de intensas pesquisas dado o grande aumento de sua incidência na população jovem, principalmente nos adolescentes. Atualmente já se descreve o que poderia ser chamado de comportamento de risco para desenvolver um distúrbio alimentar. Em geral, os pacientes com BN, AN ou TCAP, muito antes da doença estabelecida, já apresentavam alguma alteração emocional e do comportamento.

As complicações clínicas dos transtornos alimentares são variadas e estão relacionadas principalmente com a perda de peso corporal e com os métodos compensatórios utilizados pelos pacientes. Apesar da disponibilidade de tratamentos eficazes para essas doenças, um atraso importante entre o início dos sintomas e o tratamento ainda é comum. Sendo assim, o diagnóstico precoce desses distúrbios, assim como de suas complicações clínicas nem sempre são possíveis. O tratamento das complicações deve ser realizado concomitante ao acompanhamento psicoterápico e nutricional, necessitando de uma equipe multidisciplinar para o manuseio mais adequado e satisfatório dessas condições clínicas.

Segundo ZÁRATE; RODRÍGUEZ ${ }^{172}$, em 2000, é necessário vincular as distintas áreas de saúde para entender melhor sobre os transtornos alimentares e abordá-lo integralmente, não só como um sintoma isolado de outras enfermidades ou como uma mera curiosidade médica e sim, como uma síndrome bem definida.

Estudos na década de 80, nos EUA, revelaram que a anorexia nervosa era a terceira doença crônica mais comum entre adolescentes do gênero feminino (10 a 20 mulheres para 1 homem), só perdendo para asma e obesidade. Quanto à bulimia nervosa afetava 1 a 5\% desta população, sendo também mais freqüente na mulher na proporção de 1:2. (FISHER; GOLDEN; KATZMAN ${ }^{64}$, 1995). 
De acordo com a $A P A^{10}$, em 2000, a prevalência de anorexia nervosa variava cerca de 0,3 a 3,7\% e a prevalência de bulimia nervosa cerca de 1,1 a 4\%.

Com o aumento de casos de TAs, criaram-se ambulatórios de saúde específicos para esse tipo de tratamento (TEIXEIRA NETO ${ }^{161}, 2003$ ).

O tratamento de pacientes portadores de transtornos alimentares constitui-se um grande desafio para os profissionais da área de saúde em geral (SILVA; SANTOS ${ }^{146}, 2006$ ).

\subsection{CONTRIBUIÇÃO DA ODONTOLOGIA PARA O ATENDIMENTO DE PACIENTES COM TRANSTORNOS ALIMENTARES}

É de suma importância que profissionais da saúde que atuam com adolescentes e adultos jovens estejam aptos a identificar o problema, a realizar uma adequada avaliação nutricional, identificar e tratar as complicações clínicas mais freqüentes, sempre atuando em conjunto uma equipe interdisciplinar, formada por médicos, nutricionistas, psicoterapeutas e cirurgiões-dentistas. Neste caso, o cirurgião-dentista poderá tratar as conseqüências dos atos maléficos que esses transtornos causam nas estruturas dentárias, irá indicar métodos preventivos para evitar o aumento de cáries e erosões e orientar sobre o perigo de se desgastar o esmalte do dente, com escovações excessivas, logo após ter provocado o vômito, já que este se apresenta desorganizado.

Dependendo das condições clínicas do paciente, é necessário, muitas vezes em função de uma caquexia, proceder à internação da paciente para restabelecimento de sua saúde em ambiente hospitalar.

O cirurgião-dentista pode desempenhar um papel fundamental no diagnóstico precoce em pacientes portadores de transtornos alimentares, devido à presença de desgaste dentário. Para isso, há a necessidade de o profissional estar familiarizado com os sinais das doenças e preparado para realizar o tratamento educativo, preventivo e curativo nesses pacientes. 
Uma das dificuldades que o cirurgião-dentista enfrenta com pacientes portadores de TA seria o fato de que ele, sendo profissional de odontologia, não receba nenhum treinamento adequado para abordar tais questões com o paciente e encaminhá-lo para o tratamento psicológico ou até mesmo psiquiátrico frente a tais transtornos (LEITE; PINTO ${ }^{92}$, 2001).

A inclusão e o envolvimento do cirurgião-dentista em equipe multiprofissional no atendimento aos pacientes portadores de TAs é de fundamental importância para a melhoria da qualidade de vida e aumento do conforto desses pacientes podendo contribuir no diagnóstico, na prevenção e no tratamento de alterações dentárias, proporcionando benefícios à saúde bucal e geral destes pacientes.

\subsection{EQUIPE MULTIPROFISSIONAL - GRATA}

No grupo de assistência em transtornos alimentares (GRATA) do hospital das clínicas da faculdade de medicina de Ribeirão - Preto - USP, a abordagem inicial do paciente é feita em nível ambulatorial, com funcionamento semanal, atendimento clínico individual e com retornos freqüentes. De acordo com a evolução clínica esses retornos são reavaliados, agendado mais rápidos ou se uma evolução clinica desfavorável, os pacientes são internados. É oferecida uma assistência à família, com a realização de grupos de apoio (reuniões), as quais ocorrem antes do atendimento clínico individual, com duração de 2 horas, para esclarecimento de dúvidas médicas, odontológicas, nutricionais, apoio psicológico, o que certamente influencia no bom prognóstico. Essas reuniões constituem em estratégia que os membros do GRATA encontraram para levar adiante sua tarefa assistencial, buscando-se explorar os recursos criativos que são potencializados na reflexão compartilhada sobre o trabalho multidisciplinar.

Os profissionais atuam, em sua maioria, em caráter voluntário e estão inseridos em uma instituição macro-hospitalar pública, de natureza acadêmica, atendendo diferentes camadas sociais dada a sua inserção no Sistema Único de Saúde (SUS). Cada integrante desempenha um papel essencial no cuidado do 
paciente e/ou dos familiares e acompanhantes, respeitando-se o saber de cada um e sua colaboração para o tratamento global (BORGES, et al. ${ }^{34}, 2006$ ).

Neste estudo participaram pacientes portadores de BN, AN, e portadoras de TCAP. As bulímicas representaram 40\% da amostra e as anoréxicas 56,67\%. Das participantes 3,33\% apresentou-se com TCAP.

$\mathrm{Na}$ contemporaneidade tem-se observado um aumento considerável da prevalência de casos de TAs, incidindo cada vez mais em idades precoces, principalmente em adolescentes do gênero feminino, entre 18 e 30 anos, afetando $3 \%$ desta população. Os homens também são acometidos, mas em proporções menores, representando apenas $10 \%$ dos casos dos transtornos alimentares, sendo que entre os homens, a incidência é maior em homossexuais (MELIN; ARAÚJO ${ }^{107}$, 2002). No presente estudo não foi encontrado nenhum paciente portador de transtorno alimentar do gênero masculino.

Um estudo realizado por ALONSO et al. ${ }^{6}$, 2001, ressaltou que aproximadamente a metade (46\%) apresentou-se com diagnóstico de BN, seguido de 35\% com AN e 19\% na forma mista BN+AN, demonstrou uma elevada prevalência no sexo feminino entre 12 e 22 anos, observou também um aumento no gênero masculino, de acordo com PARGA; HIGHSMITH; MEDIZAZCOITIA ${ }^{125}$, 1996; BIDWELL $^{32}, 1999$.

Os resultados desta pesquisa apontaram uma média de idade de 26,8 anos, indo ao encontro aos achados de MELIN; ARAÚJO ${ }^{107}$, 2002. Este fator sinaliza a importância de campanhas educativas para as adolescentes sobre a preocupação exagerada com a aparência.

\subsection{PROBLEMAS BUCAIS EM PACIENTES COM TRANSTORNOS ALIMENTARES}

Manifestações odontológicas são de grande relevância, razão pela qual devem ser devidamente reconhecidas previamente e tratadas oportunamente.

A dieta rica em carboidratos e açúcares consumida pelo paciente com BN e TCAP favorece a presença de cáries que são agravadas devido à xerostomia. Esta 
pode ser acentuada pelo uso de medicamentos antidepressivos usados pelos pacientes portadores de transtornos alimentares durante o tratamento. Pode ocorrer aumento assintomático das parótidas, irritação da mucosa oral, queilite, sensibilidade dentária à alteração da temperatura, mordida aberta anterior e bruxismo (RYTÖMAA, et al. $\left.{ }^{137}, 1998\right)$.

Nos pacientes bulímicos observam-se três sinais relativamente simples na realização do exame bucal: a hipertrofia das glândulas parótidas, que confere ao paciente face de lua cheia quando o grau é intenso; lesão no dorso da mão ou nos dedos (sinal de Russel), decorrente da indução de regurgitação; e desgaste dentário provocado pelo suco gástrico dos vômitos levando a descalcificação (CORDÁS; BUSSE $^{51}$, 1995). No presente estudo verificou-se em uma das pacientes a hipertrofia das glândulas parótidas.

As alterações bucais mais freqüentes estão associadas aos hábitos purgativos, particularmente a indução voluntária de vômitos. O ato de regurgitar provoca vários problemas dentários, em especial o desgaste dentário. O processo erosivo pode ser devido a causas intrínsecas, em pacientes que regurgitam, e causas extrínsecas, largamente atribuídas a excesso de consumo de dietas ácidas que levam à queda do pH (CALDEIRA; NÁPOLE; BUSSE $\left.{ }^{42}, 2000\right)$.

\subsection{CONDIÇÕES DE DESGASTE DENTÁRIO}

Nos últimos anos, têm-se buscado formas de obtenção de um diagnóstico claro e preciso acerca da prevalência de erosão dentária em diferentes populações, por meio da utilização de índices epidemiológicos. Vários índices têm sido propostos, porém, há uma grande dificuldade em se medir a erosão dentária. A maioria desses índices mede o desgaste dentário, nesse caso, podem ser incluídas lesões de erosão, abrasão, atrição e abfração ao mesmo tempo (BARTLETT; PHILLIPS; SMITH ${ }^{26}$, 1999; LITONJUA et al. ${ }^{95}$, 2003).

O índice proposto para medir erosão dentária elaborado por ECCLES ${ }^{56}$, 1979, classifica a erosão de acordo com a severidade clínica apresentada (Classe I, II e III) e avalia a localização e o grau de envolvimento das superfícies de esmalte e 
dentina.

O índice mais utilizado em levantamentos epidemiológicos foi proposto por SMITH; KNIGHT ${ }^{150}$, 1984, porém seus critérios para avaliar extensão da dentina envolvida, geram dúvidas para o examinador em estudos epidemiológicos e clinicamente tem uma visibilidade melhor. Ainda, deve-se observar que não contempla a condição de dente não avaliado.

O'BRIEN ${ }^{120}$, 1994, desenvolveu o índice de desgaste dentário para ser aplicado no Reino Unido analisando profundidade e área envolvida, aplicando os códigos numéricos. Entre os critérios propostos não contemplava o dente restaurado por causa do desgaste e divide a área envolvida em até $1 / 3$, entre 1/3 e 2/3 e mais de 2/3, critério que dificulta a avaliação em levantamentos epidemiológicos.

A proposta de O'SULLIVAN ${ }^{121}$, 2000, foi elaborada para investigação de erosão dentária, e não de desgaste dentário, visto que um mesmo paciente pode apresentar fatores etiológicos associados determinados pelo diferentes tipos de desgaste. O índice adota letras para relacionar a superfície dentária envolvida, números para identificar severidade e algarismos mais (+) e menos (-) para relacionar a extensão da superfície dentária envolvida com a alteração. Para realização da adoção deste índice, observa-se a grande dificuldade no treinamento do examinador reduzindo a concordância intra e inter examinador, visto que o número de códigos adotados é muito grande para esta análise.

Vale ressaltar que os índices acima citados têm reconhecimento científico, mas muitas vezes em estudos epidemiológicos esta validação torna-se de baixa reprodutividade.

SALES PERES et al. ${ }^{138}, 2005$, após a avaliação dos quatro índices acima citados, em atividades de calibração identificou alguns critérios que poderiam favorecer a realização de estudos epidemiológicos de desgaste dentário. Incorporou o código 4 para contemplar dente restaurado por causa de desgaste dentário, relaciona letras e números para separar a ocorrência de desgaste em dentes decíduos e permanentes e adota o código 9, para superfícies não avaliadas. Elaboraram uma ficha especifica para registrar os códigos, incluindo todos os dentes e analisando as superfícies vestibular, lingual, incisal/oclusal. 
Muitos pacientes apresentam desgastes dentários com uma etiologia diversa que não se pode indicar os resultados das mesmas como uma única e precisa categoria entre erosão, abrasão, atrição ou abfração (BASSIOUNY; ZARRINNIA $^{29}$, 2004). Esta afirmação dá suporte aos pesquisadores que adotam índice epidemiológico para desgaste e não somente para erosão (SMITH; KNIGHT ${ }^{150}$, 1984; SALES PERES et al. $\left.{ }^{138}, 2005\right)$.

Ao analisar os graus de severidade de desgaste dentário, encontra-se um elevado número de desgaste grau 2 por indivíduo com transtornos alimentares (63\%), o que vai de encontro com os achados de ALONSO et al. ${ }^{6}, 2001$.

Em relação ao número de pacientes para o presente estudo, adotou-se uma amostra de 30 indivíduos similar a outros trabalhos realizados (HELLSTRÖM ${ }^{78}$, 1977; PASZYNSKA et al. ${ }^{127}$, 2006), frente à dificuldade de se encontrar esse grupo de pacientes. Foram incluídas todas as pacientes atendidas pelo GRATTA e que aceitaram participar deste estudo.

Nos resultados sobre a prevalência de desgaste dentário em pacientes portadores de bulimia nervosa, RYTÖMAA et al. ${ }^{137}$, em 1998 , verificaram que 90\% desses pacientes apresentavam algum grau de desgaste. Na presente pesquisa, a concentração foi maior, visto que $100 \%$ das pacientes se apresentaram com diferentes graus de desgaste dentário.

Segundo ROBERTS; $\mathrm{LI}^{134}$, 1987, pacientes com anorexia nervosa também apresentam desgaste na superfície dos dentes, podendo estar relacionados com a depressão e, provavelmente por isso, não havia preocupação e interesse em manter cuidados específicos com a higiene bucal. Neste estudo encontrou-se uma prevalência de $75 \%$ de desgaste dentário com severidade grau 2, demonstrando como a extensão ocorreu em dentina, o que muitas vezes pode gerar hipersensibilidade dentinária.

Diante da discussão apresentada, pôde-se perceber a complexidade e a importância de trabalhos acerca da interação entre pacientes portadores de transtornos alimentares com a prevalência e severidade de desgaste dentário. É importante ressaltar a necessidade de mais trabalhos existentes nesta área, para que resultados conclusivos possam ser adotados pela literatura científica. 
É de grande importância identificar os diferentes tipos de desgaste dentário, principalmente em estágio inicial, realizar um diagnóstico diferencial e identificar os fatores etiológicos, implementar um programa preventivo para evitar a evolução do quadro ou mesmo o aparecimento de novas lesões e definir um plano de tratamento adequado para cada caso.

Neste trabalho, observou-se a necessidade de um protocolo de atendimento específico aos pacientes portadores de transtornos alimentares, proporcionando a integração dos cuidados odontológicos aos da equipe multiprofissional. A participação do cirurgião-dentista durante as discussões de casos junto à equipe, favorece a implementação de atividades educativas e preventivas, bem como a avaliação das condições de saúde bucal de portadores de transtornos alimentares e encaminhamento para tratamento odontológico quando necessário. O correto acompanhamento do paciente e motivação irá ocasionar uma melhora no tratamento, na prevenção e no prognóstico na maioria dos casos. 


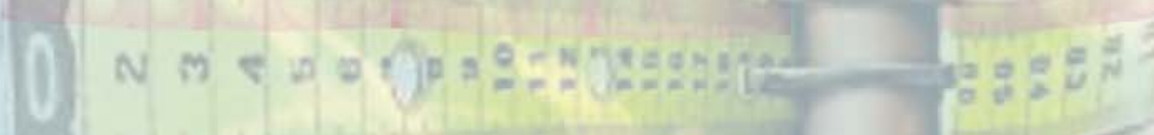

7 CONCLUSÕES 



\section{CONCLUSÕES}

Pela metodologia aplicada e pelos resultados obtidos, torna-se possível apresentar as seguintes conclusões:

$\checkmark$ Todos os pacientes portadores de transtornos alimentares, avaliados neste estudo, apresentaram algum grau de desgaste dentário.

$\checkmark$ Em relação à severidade, a mais freqüente foi com envolvimento em dentina (grau 2).

$\checkmark$ Os dados demonstraram que a superfície dentária mais acometida pelo desgaste dentário foi à superfície oclusal/incisal.

$\checkmark$ Quanto ao número de escovações diárias, houve um predomínio na média de 3 vezes ao dia.

$\checkmark$ Metade da amostra relatou utilizar o movimento circular na escovação dentária.

$\checkmark$ Com relação ao hábito de ingerir bebidas, como refrigerantes e sucos, a maioria deu preferência para o refrigerante "coca-cola" e aos sabores cítricos para os sucos.

$\checkmark$ Dos pacientes que apresentaram desgaste dentário grau 4 , todos ingeriam coca-cola.

$\checkmark$ A maioria dos pacientes afirmaram ter um ou mais hábitos bucais, como ranger os dentes, morder objetos, roer unha, mascar chiclete, morder língua e lábios, sendo que somente ranger e apertar os dentes apresentaram significância estatística. 




\section{REFERÊTNCIAS}

1 Abott DW, Ackerman SH, Agras WS, Banzhaf D, Barber J, Bartlett JC, et al. Practice guideline for eating disorders. Am J Psychiatr. 1993;150(2):212-214.

2 Addy M, Mostafa P, Newcombre RG. Dentine hypersensitivity: the distribution of recession, sensitivity and plaque. J Dent. 1987;15(6):242-48.

3 Al-Dlaigan $\mathrm{YH}$, Shaw L, Smith A. Dental erosion in a group of British 14-yearold-children. Part I: prevalence and influence of differing socioeconomic backgrounds. Br Dent J. 2001;190(3):145-49.

4 Aine L, Baer M, Maki M. Dental erosions caused by gastroesophageal reflux disease in children. ASDC J Dent Child. 1993;60(3):210-14.

5 Almeida PEM. Terapia comportamental para transtornos alimentares: um estudo exploratório das possíveis variáveis envolvidas na origem e manutenção das chamadas anorexia e bulimia nervosa [dissertação-mestrado]. São Paulo (SP). Pontifícia Universidade Católica de São Paulo; 2001.

6 Alonso C, Sabás M, Castilho AM, Weisstaub G, Pascual DM. Transtornos de La conducta alimentaria: repercusiones a nível oral. Rev Assoc Odontol Argent. 2001;89(4):390-95.

7 Alvarenga MA. Mudança na alimentação e no corpo ao longo do tempo. In: Philippi ST, Alvarenga M. Transtornos Alimentares. uma visão nutricional. São Paulo: Manole; 2003. p. 2-20.

8 American Dietetic Association. Position of the american dietetic association: Nutrition intervention in the treatment of anorexia nervosa, bulimia nervosa, and other eating disorders. J Am Diet Assoc. (ADA) 2006;106(12):2073-82.

9 American Psychiatric Association. Diagnostic and statistical manual of mental disorders (DSM - IV). $4^{\text {th }}$ ed. Washington: APA; 1994.

10 American Psychiatric Association. Diagnostic and statistical manual of mental disorders (DSM - IV-TR). Press. $4^{\text {th }}$ ed. Washington: APA; 2000. 
11 American Psychiatric Association. Practice guideline for the treatment of patients with eating disorders. $1^{\text {st }}$ ed. Washington: APA; 2006.

12 Amigo VL. Comorbidades clínicas e psiquiátricas. In: Nestor S. Guia de transtornos alimentares e obesidade. São Paulo: Manole; 2005.

13 Appolinário JC. Transtornos alimentares. In: Nardi AE, Bueno JR. Diagnóstico e tratamento em psiquiatria. Rio de Janeiro: Medsi; 2000. p. 480.

14 Appolinário JC, Claudino A. Transtornos Alimentares. Rev Bra Psiquiatr. 2000;22(2):28-31.

15 Appolinário JC, Córdas TA, Claudino AM. Transtornos alimentares: apresentação. Rev Bras Psiquiatr. 2002;24(Suppl 3):1-2.

16 Appolinário JC, Coutinho W, Povoa LC. O transtorno do comer compulsivo no consultório endocrinológico: comunicação preliminar. $\mathrm{J}$ Bras Psiquiatr. 1995;44(1):46-49.

17 Appolinário JC, Godoy-Matos A, Fontenelle LF, Carraro L, Cabral M, Vieira A, Coutinho W. Na open-label Trial of sibutramine in obese patients with binge eating disorder. J Clin Psychiatr. 2002;63(1):28-30.

18 Assumpção CL, Cabral MD. Complicações clínicas da anorexia nervosa e bulimia nervosa. Rev Bras Psiquiatr. 2002;24(3):29-33.

19 Azevedo AMC. Considerações diagnósticas na anorexia nervosa: análise a partir de sete casos clínicos [dissertação - mestrado]. São Paulo (SP): Escola Paulista de Medicina, Universidade Federal de São Paulo; 1996.

20 Azevedo AMC, Abuchaim ALG. Bulimia nervosa: classificação diagnóstica e quadro clínico. In: Nunes MAA, Appolinário JC, Abuchaim ALG, Coutinho W. Transtornos alimentares e obesidade. Porto Alegre: Artmed; 1998. p. 31-39.

21 Azevedo AP, Santos CC, Fonseca DC. Transtorno da compulsão alimentar periódica. Rev Psiq Clin. 2004;31(4):170-72. 
22 Barata TJE, Fernandes MILP, Fernandes JMA. Lesões cervicais não cariosas: condutas clínicas. ROBRAC. 2000;9(28):22-24.

23 Baratieri LN. Odontologia restauradora: fundamentos e posibilidades. São Paulo: Santos; 2001.

24 Bargen JA, Austin LT. Decalcification of teeth as a result of obstipation with long continued vomiting: Report of a case. J Am Dent Assoc. 1937;24(8):1271-273.

25 Bartlett DW. The role of erosion in tooth wear: aetiology, prevention and management. Int Dent J. 2005;55(4 Suppl 1): 277-84.

26 Bartlett DW, Phillips K, Smith B. A difference in perspective - the North American and European interpretations of tooth wear. Int J Prosthodont. 1999;12(5):401-8.

27 Basdevant A, Pouillon M, Lahlou N, Le Barzic M, Brillant M, Guy-Grand B. Prevalence of binge eating disorder in different populations of French women. Int J Eating Disord. 1995;18(4):309-15.

28 Bassiony MA, Zarrinnia K. Dental erosion: a complication of pervasive developmental disorder. J Clin Pediatr Dent. 2004;28(3):273-8.

29 Beaumont PJV. The history of eating and dieting disorders. J Appl Nutr. 1991;1(2):9-20.

30 Behar V. Abordagem psicoterápico do paciente com bulimia nervosa. Rev Insight-psicoterapia. 1994;43(1):11-14.

31 Bell RM. Hoy anorexia. Chicago: University of Chicago Press; 1995.

32 Bidwell HLD. Bulimia-induced dental erosion in a male patient. Quintessence International. 1999;30(1):135-138.

33 Borges MBF. Estudo do transtorno da compulsão alimentar periódica em população de obesos e sua associação com depressão e alexitimia [dissertação - mestrado]. São Paulo (SP). Universidade Federal de São Paulo; 1998. 
34 Borges NJBG, Sicchieri JMF, Ribeiro RPP, Marchini JS, Santos JE. Transtornos alimentares - Quadro clínico. Medicina (Ribeirão Preto). 2006;39(3):340-48.

35 Boskind-White M, White-JR W. Bulimarexia: a historical-sociocultural perspective. In: Brownell KD, Foreyt JP. Handbook of eating disorders Psysiology and treatment of obesity, anorexia, and bulimia. USA: Basic Books; 1985. p. 353-66.

36 Brunton PA, Hussain A. The erosive effect of herbal tea on dental enamel. J Dent. 2001;29(8):517-20.

37 Bryant-Waught R, Lask B. Annotation: eating disorders in children. J Child Psychol Psuchiatry. 1995;36(1):191-202.

38 Bulik CM, Sullivan PF, Kendler KS. Medical and psychiatric morbidity in obese women with and without binge eating. Int J Eat Disord. 2002;32(1):72-78.

39 Burke FJT, Bell TJ, Ismail N, Hartley P. Bulimia: implications for the practicing dentist. Br Dent J. 1996;180(11):421-26.

40 Busse SR. Anorexia, bulimia e obesidade. Barueri: Manole; 2004.

41 Busse SR, Silva BL. Transtornos Alimentares. In: Busse SR. Anorexia, bulimia e obesidade. Barueri: Manole; 2004. p. 31-110.

42 Caldeira TH, Nápole RCD, Busse SR. Erosão dental e a contribuição do cirurgião-dentista no diagnóstico de bulimia nervosa. Rev Assoc Paul Cir Dent. 2000;54(6):465-67.

43 Campos R. Imagnes irreais. Rev Viver Psicol. 2002;109(2):24-29.

44 Carlat DJ, Camargo JRCA. Review of bulimia nervosa in males. Am J Psychiatr. 1991;148(7):831-43.

45 Casper RC. On the emergence of bulimia nervosa as a síndrome: a historical view. Int J Eat Disord. 1983;2(1):3-16. 
46 Castro JM. Goldstein SJ. Eating attitudes and behaviors of pre-and postupuberal females: clues to the etiology of eating disordens. Physiol Behav. 1995;58(1):5-23.

47 Cereser MG, Cordás TA. Transtornos alimentares: anorexia nervosa e bulimia. São Paulo: Atheneu; 2001. p. 269-76.

48 Claudino AM; Borges MBF. Critérios diagnóstico para os transtornos alimentares: conceitos em evolução. Rev Bras Psiquiatr. 2002;24(3):7-12.

49 Cobelo AW. O papel da família no comportamento alimentar e nos transtornos alimentares. In: Philippi ST. Alvarenga M. Transtornos alimentares. Uma visão nutricional. São Paulo: Manole; 2004. p. 119-129.

50 Cordás TA. Transtornos alimentares: classificação e diagnóstico. Rev Psiquiatr Clin. 2004;31(4):154-57.

51 Cordás, TA, Busse SR. Transtornos alimentares: anorexia e bulimia nervosa. In: Louzã Neto MR, Motta T, Wang YP, Elkis H. Psiquiatria Básica. Porto Alegre. Artes Médicas; 1995. p. 273-82.

52 Cordás TA, Claudino AM. Transtornos alimentares: fundamentos históricos. Rev Bras Psiquiatr. 2002;24(Suppl 3):3-6.

53 Coutinho W. Estudo da compulsão alimentar periódica em pacientes que procuram tratamento médico para emagrecer [tese - doutorado]. São Paulo (SP). Universidade Federal de São Paulo; 2000.

54 De Conte FNB, Moreno RA. Avaliação da bulimia nervosa em pacientes com transtornos do humor através da escala BITE: resultados preliminares. Ver ABP-APAL. 1995;17(2):72-74.

55 Devlin MJ. Assessment anda treatment of BED. Psychiatr Clin $N$ Am. 1996;19(4):761-72.

56 Eccles JD. Dental erosion of nonindustrial origin. A clinical survey and classification. J. Prosthet Dent. 1979;42(6):649-53. 
57 Eccles JD. Tooth surface loss from abrasion, atrition and erosion. Dent Update. 1982;9(7):373-82.

58 Emans SJ. Eating disordens in adolescent girls. Pediatr Inter. 2000:42(1):1-7.

59 Fairburn CG. Psychological and social probems associated with binge eating. In: Fairbum CG. Overcoming Binge Eating. New York: The Guilford Press;1995. p 42-66.

60 Fairburn CG, Cooper Z, Doll HS, Norman P. O'Connor M. The natural course of bulimia nervosa and binge eating disorder in young women. Arch Gen Psychiatr. 2000;57(7):659-65.

61 Fairburn CG, Harrison PJ. Eating disorders. J Lancet. 2003;361(1):407-16.

62 Fiates GMR, Salles RK. Fatores de risco para o desenvolvimento de distúrbios alimentares: um estudo em universitárias. Rev. Nutr. 2001:14(3):3-6.

63 Ficther MF. Bulimia nervosa and bulimic behaviour. In: Ficter MF. Bulimia nervosa: Basic research, diagnosis and therapy. Chichester: John Wley \& Sons; 1990.

64 Fisher W, Golden NH, Katzman DK. Eating disordens in adolescence: a background paper. J Adolesc Health. 1995; 16(6):420-37.

65 Friedman MA, Brownell KD. Psychological correlates of obesity: moving to the next research genereation. Psychol Bull. 1995;11(7):3-20.

66 Garfinkel PE. Classification and diagnosis of eating disorders. In: Brownell KD, Fairburn CG. Eating Disorders and Obesity. A Comprehensive Handbook. New York: The Guilford Press; 1995. p. 125-134.

67 Geliebter A. New developments in binge eating disorder and the night eating syndrome. Appetite. 2002;39(1):175-77.

68 Giunta JL. Dental erosion resulting from chewable vitamin C tablets. J Am Dent Assoc. 1983;107(2):253-56. 
69 Goldfeim JA, Walsh BT, LaChauseé JL, Kissileff HR, Devlin MJ. Eating behavoir in binge eating disorder. Int J Eat Disord. 1993;14(1):427:31.

70 Grilo CM. Binge eating disorder. In: Fairburn CG, Brownell KD. Eating disordens and obesity: a comprenhensive handbook. $2^{\text {th }} .2002 ;$ p. $178-82$.

71 Grippo JO. Abfractions: a new classification of hard tissue lesions of teeth. J Esthet Dent. 1991;3(1):14-19.

72 Gull W. Anorexia nervosa. Trans Clin Soc. 1874;1:22.

73 Habermas T. The psychiatric history of anorexia nervosa and bulimia nervosa: weight concerns and bulimic symptoms in early case reports. Int $\mathrm{J}$ Eat Disord. $1989 ; 29(6) 403-10$.

74 Hammadeh M. Rees JS. The erosive susceptibility of cervical versus occlusal enamel. Eur J Prosthodont Dent. 2001;9(1):13-17.

75 Hay PJ. Epidemiologia dos transtornos alimentares: estado atual e desenvolvimentos futuros. Rev Bras Psiquiatr. 2002;24(Suppl 3)13:17.

76 Hay PJ. Fairburn C. The validity of the DSM - IV scheme for classifying bulimic eating disorders. Int J Eat Dis. 1998;23(1):7-15.

77 Hazelton LR, Faine MP. Diagnosis and dental management of eating disorder patients. Int J Prosthodont. 1996;9(1):65-73.

78 Hellström I. Oral complications in anorexia nervosa. Scand J Dent Res. 1977;85(1):71-86.

79 Herzorg DB, Dorer DJ, Kell PK, Selwyn SE, Ekeblad ERA, Flores AT. Patterns and predictors of recovery in anorexia nervosa and bulimia nervosa. J Am Child Adolesc Psychiatr. 1993;32(1)835-42.

80 Hetherington MM. Eating disorders: diagnosis, etiology, and precention. J Nutr. 2000;16(7-8):547-51. 
81 Hoek HW, Hoeken D. Review oh the prevalence and incidence of eating disorders. J Eat Disord. 2003;34(4):383-96.

82 Hooper S, West NX, Sharif N, Smith S, North M, De'Ath J et al. A comparision of enamel erosion by a new sports drink compared to two proprietary products: a controlled, crossover study in situ. J. Dent. 2004;32(7):541-45.

83 Imfeld T. Dental erosion. Definition, classification and links. Eur J Oral Sci. 1996;104(2):151-55.

84 Jones JM, Bennett S, Olmsted MP, Lawson L, Rodin G. Disordered eating attitudes and behaviours in teenaged girls: a school-based study. Can Med Assoc J. 2001;165(1):547-52.

85 Kaplan HL, Sadock BJ, Grebb JÁ. Compêndio de Psiquiatria. $7^{\text {th }}$ ed. Porto Alegre: Artmed; 1977. p.648-55.

86 Kaufman A. Transtornos alimentares na adolescência. Rev Bras Med. 2000;57(1):60-64.

87 Killen JD, Taylor CB, Hammer LD, Litt I, Wilson DM, Rich T, Hayard. C, Simmonds $B$, Kraemer $\mathrm{H}$, Varady $\mathrm{A}$. An attempt to modify unhealthful eating attitudes and weight regulation practices of young adolescent girls. Int $\mathrm{J}$ Eat Disord. 1993; 13(4):369-84.

88 Lambrechts P, Van Meerbeek B, Perdigão J, Gladys S, Braem M, Vanherie G. Restorative therapy for erosive lesions. Eur J Oral Sci. 1996;104(2):229-40.

89 Lasater LM, Mehler PS. Medical complications of bulimia nervosa. Eat Behav. 2001;2(3):279-92.

90 Laségue EC. Anorexie hysteriqué. Arch Gen Medic. 1873:21(1):385-403.

91 Lee WC, Eakle WS. Possible role of tensite stress in the etiology of cerical erosive lesions of teeth. J Prosthet Dent. 1984;52(3):374-80.

92 Leite A, Pinto L. Anorexia e bulimia afetam a saúde bucal. Rev Assoc Paul Cir. 2001;55(5):313-18. 
93 Levitch LC, Bader JD, Shugars DA, Heymann HO. Non-carious cervical lesions. J Dent. $1994 ; 22(4): 195-207$.

94 Lindholm L, Wilson GT. Body image assessment in patients with bulimia nervosa and normal controls. Int J Eat Disord. 1998;7(1):527-539.

95 Litonjua LA, Andreana S. Bush PJ, Cohen RE. Tooth wear: attrition, erosion, and abrasion. Quintessence Int. 2003;34(6):435-46.

96 Louza Neto MR, Da Motta T, Wang YP, Elkis H. Psiquiatria Básica. Porto Alegre: Artes Médicas;1995.

97 Lozer AC, Resende PL, Batitucci E, Batittucci MHG. Aspectos oclusais nas lesões cervicais não-cariosas. UFES Rev Odontol. 2000;2(2):36-41.

98 Lucas AR. Beard CM, O'Fallon WN, Kurland LT. 50 years trends in incidence of anorexia nervosa in Rochester, Minnesota: a population-based study. Am J Psychiatr. 1991; 148(7):917-22.

99 Lussi A,. Dental erosion clinical diagnosis and case history taking. Eur J Oral Sci. 1996;104(2):191-98.

100 Lussi A, Jaeggi T, Scharer S. The influence of different factors on in vitro enamel erosion. Caries Res. 1993;27(5):387-93

101 Lussi A, Jaeggi T, Zero D. The role of diet in the aetiology of dental erosion. Caries Res. 2004;38(1):34-44.

102 Magalhães VC, Mendonça S. Transtornos alimentares em universitárias: estudo de confiabilidade da versão brasileira de questionários autopreenchíveis. Rev Bras Epidemiol. 2005;8(3):236-45.

103 Mahan LK. Escott-Stump S. Alimentos, nutrição e dietoterapia. São Paulo: Roca; 2002.

104 Mahan LK, Stump SE. Nutrição na adolescência. In: Mahan LK, Escott-Stump S. Alimentos, nutrição e dietoterapia, $9^{\text {th }}$ ed. São Paulo: Roca; 1998. p. 279283. 
105 Malcolm A. Rumination syndrome. Mayo Clin Proc. 1997;72(7):646:52.

106 Maso AA, Ayala MC, Rivas G, Mora T. Bulimia. Acta Odontol Venez. 2001;39(2):70-73.

107 Melin A, Araújo AM, Transtornos alimentares em homens: um desafio diagnóstico. Rev Bras Psiquiatr. 2002;24(3):73-76.

108 Meurman JH, Frank RM. Scanning electron microscopic study of the effect of salivary pellicle on enamel erosion. Caries Res. 1991;25(1):1-6.

109 Millward A, Shaw L, Smith AJ, Rippin JW. The distribution and severity of tooth wear and the relationship between erosion and dietary constituents in a group of children. Int J Paed Dent. 1994;4(3):151-57.

110 Mondelli J. Estética e cosmética em clínica integrada restauradora. São Paulo: Quintessence;2003.

111 Morandé G, Celada J, Casas JJ. Prevalence of eating didorders in spanish scholl-age population. J Adolesc Heath. 1999;24(1):212-19.

112 Morgan CM, Azevedo AMC. Aspectos sócio-culturais dos transtornos alimentares. Psychiatry Brazil. 1998;3(2):1-8.

113 Morgana CM. Vecchiattia IR, Negrão AB. Etiologia dos transtornos alimentares: aspectos biológicos, psicológicos e sócio-culturais. Rev Bras Psiquiatr. 2002;24(Suppl 3):18-23.

114 Morton R. Phthisiologia: or a treatise of consumption. London: Smith and Walford; 1694. p. 4-10.

115 Moss SJ. Dental erosion. Int Dent J. 1998;48(6):529-39.

116 Murakami C, Corrêa MSNP, Rodrigues CRMD. Prevalência de erosão dental em crianças e adolescentes de São Paulo. UFES Rev Odontol. 2006;8(1):4-9. 
117 Napolitano MA; Head S; Babyak MA; Blumenthal JÁ. Binge eating disorder and night eating syndrome: psychological and behavioral characteristics. Int $\mathrm{J}$ Eat Disord. 2001; 30(2):193-203.

118 Nunes MAA, Appolinário JC, Abuchaim ALG, Coutinho W. Transtornos Alimentares e obesidade. Porto Alegre: Artmed; 1998.

119 Nunes MAA, Apolinário JC, Galvão AL, Coutinho W. Transtornos alimentares e obesidade. 2 ed. Porto Alegre: Artmed; 2006.

120 O'Brien M. Children's dental helth in the United Kingdom 1993. Office of population censuses and surveys. London: HMSO, 1994.

121 O'Sullivan EA. Anew index for the measurement or erosion in children. Eur J Paed Dent. 2000;2:69-74.

122 Oginni O, Olusile AO. The prevalence, aetioly and clinical appearance of tooth wear: The Nigerian experience. Int Dent J. 2002;52(4):268-72.

123 Organização Mundial de Sáude (OMS). Levantamentos básicos em saúde bucal 4 ed. São Paulo: Santos; 1999.

124 Organização Mundial de Saúde (OMS). Classificação de transtornos mentais e de comportamento da CID-10. Descrições clínicas e diretrizes diagnósticas. São Paulo: Artes Médicas; 1993.

125 Parga JAMV, Highsmith Del Rio J, Medinazcoitia LC. La Bulimia. Un problema actual. Características generales y odontológicas. Rev Eur Odontoestomatol.1996;8(5):283-88.

126 Parry-Jones B, Parry-Jones WL. Bulimia: An archival review of its history in psychossomatic medicine. Int J Eat Disord. 1991;10(1):129-143.

127 Pasynska E, Limanowska-Shaw H, Slopien A, Rajewski A. Evaluation of oral health in bulimia nervosa. Psychiatr Pol. 2006;40(1):109-18.

128 Pegoraro CN, Sakamoto FF, Domingues LA. Perimólise: etiologia, diagnóstico e prevenção. Rev Assoc Paul Cir Dent. 2000;54(2):156-61. 
129 Philippi ST, Alvarenga M. Transtornos alimentares: uma visão nutricional. In: Cordás TA, Salzano FT, Rios SR. Os transtornos alimentares e a evolução no diagnóstico e no tratamento. Barueri: Manole; 2004. p. 39-62.

130 Pinzon V, Nogueira CF. Epidemiologia, curso e evolução dos transtornos alimentares. Rev Psiquiatr Clin. 2004;31(4):158-60.

131 Piran N. Prevention of eating disorders: direCtions for future research. Psychopharmacol Bull. 1997;33(3):419-23.

132 Pop-Jordanova N. Psychological characteristics and biofeedback mitigarion in preadolescents with eating disorders. Pediatr Edicion Int. 2000;42(1):76-81.

133 Robb ND, Smith BG. Anorexia and bulimia nervosa (the eating disorders); conditions of interest to the dental practitioner. J. Dent. 1996;24(2):7-16.

134 Roberts MW, LI SH. Oral findings in anorexia nervosa and bulimia nervosa: a study of 47 cases. J Amer Dent Ass. 1987;115(1)407-10.

135 Romano ra. Itokazu, FM. Bulimia Nervosa: Revisão da Literatura. Psicologia: Reflexão e CRÍTICA. 2002; 15(2):407-12.

136 Russel GFM. Anorexia nervosa: its identity as an illness and its treatment. In: Price, PH. Modern trends in psychological medicine. London: Butterworth; 1970.p.131-164.

137 Rytömaa I, Järvinen V, Kanerva R, Heinonem OP, Bulimia and tooth erosion, Acta Odontol Scand. 1998;56(1):36-40.

138 Sales Peres SHC, Mendes Silva H, Sales Peres A, Lauris JRP, Bastos JRM, Buzalaf MAR. Estudo da prevalência do Índice de Desgaste Dentário (IDD). Brz. Oral Res. 2005;19(1):31. Apresentando na 22 ${ }^{\text {nd }}$ Annual SBPqO Meeting; 2005. Atibaia, SP.

139 Salzano FT, Cordas TA. Tratamento farmacológico de transtorno alimentar. Rev Psiquiatr Clin. 2004;31(4):188-94.

140 Santacruz H. Anorexia y bulimia; conflitos com el cuerpo. Acta Med Colomb. 1997;22(3):105-10. 
141 Santos RL, Barbosa RPS. Erosão dentária e perimólise: Guia para orientação dos Cirurgiões-Dentistas. Odontol Clín-Cient. 2004;3(2):147-48.

142 Scmidt U, Treasure J. Eating disorders and the dental practitioner. Eur J Prosthodont Restor Dent. 1997;5(4):161-67.

143 Seabra BGM, Almeida RQ, Ferreira JMS, Seabra FRG. Anorexia nervosa e bulimia nervosa e seus defeitos sobre a saúde bucal. Rev Bras Patol Oral. 2004;3(4):195-98.

144 Shaw L, Smith AJ. Dental erosion - the problem and some practical solutions. Brit Dent J. 1998;186(3);115-18.

145 Shipley S, Taylor K, Mitchell W. Identifying causes of dental erosion. Gen Dent. 2005;53(1):73-75.

146 Silva LM, Santos MA. Construindo pontes: relato de experiência de uma equipe multidisciplinar em transtornos alimentares. Medicina (Ribeirão Preto). 2006;39(3):415-24.

147 Silverman JÁ. Historical development. In: Halmi KA. Psychobiology and Treatment of Anorexia Nervosa and Bulimia Nervosa. $1^{\text {st }}$ ed. Washington: American Psychiatric Press; 1993. p.3-17.

148 Smith BGN. Toothwear: aetiology and diagnosis. Dent Update. 1989; 16(5):20412.

149 Smith BGN, Bartlett DW, Robb ND. The prevalence, etiology and management of tooth wear in the United Kingdom. J Prosthet Dent. 1997;78(1):367-72.

150 Smith BGN, Knight JK. Na index for measuring the wear of teeth. $\mathrm{Br}$ Dent $\mathrm{J}$. 1984;156(12):435-38.

151 Smith BGN, Roob ND. The prevalence of tooth wear in 1007 dental patients J Oral Rehabil. 1996;23(1):232-39.

152 Smith C, Steiner H. Psychophatology in anorexia nervosa and depression. J Am Acad Child Adolesc Psychiatr 1992;31(5):841-46. 
153 Souto S, Ferro-Bucher JSN. Práticas indiscriminadas de dietas de emagrecimento e o desenvolvimento de transtornos alimentares. Rev Nutr. 2006;19(6):693-04.

154 Spigset O. Oral symptoms in bulimia nervosa. Acta Odont Scand. 1991;49(1):335-39.

155 Spitzer RL, Yanovski SZ, Wadden T, Wing R, Marcus MD, Stunkard A et al. Binge eating disorder and bulimia nervosa in a community sample. Int $\mathrm{J}$ Eat Disord. 1993; 13(1):137-53.

156 Striegel RH, Cachelin FM, Dohm FA, Pike KM, Wilfley DE, Fairburn CG. Comparison of binge eating disorder and bullimia nervosa in a community sample. Int J Eat Disord. 2001;29(2):157-65.

157 Stunkard AJ. Eating patterns and obesity. Psychiatr Quarterly. 1959;33(1):28495.

158 Stunkard Aj, Allison KC. Two forms of disordered eating in obesity: binge eating and night eating. Int J Obes. 2003;27(1):1-12.

159 SzmuklerGL. The epidemiology of anorexia nervosa and bulimia. Psychiatry Res. 1985;19(3):143-53.

160 Tanaka M, Naito T, Yokota M, Kohno M. Finite element analysis of the posible mechanism of cerical lesión formation by oclusal force. J Oral Rehabil. 2003;30(1)60-67.

161 Teixeira Neto F. Nutrição Clínica. Rio de Janeiro: Guanabara Koogan; 2003.

162 Tem Cate JM, Imfeld T. Dental erosion, summary. Eur J Oral Sci. 1996;104(2):41-44.

163 Traebert J, Moreira EAM. Transtornos alimentares de ordem comportamental e seus efeitos sobre a saúde bucal na adolescência. Pesqui Odontol Bras.2001;15(4):359-63.

164 Tylend CA. Bulimia nervosa: its effect on salivary chemistry. J Am Dent Assoc. 1991;122(7):37-41. 
165 Van der Ham T, Meulman JJ, Van Strien DC, Engeland VH. Empirically based subgrouping of eating disorders in adolescents: a longitudinal perspective. $\mathrm{Br} \mathrm{J}$ Psychiatr. 1997;170(1):363-68.

166 Vandereycken W. Emergence of bulimia nervosa as a separate diagnostic entity: review of the literature from 1960 to 1979. Int J Eating Disord.1994;16(2):105-16.

167 Vilela JEM, Lamounier JA, Filho MAD, Barros Neto JR, Horta GM. Transtornos alimentares em escolares. J Pediatr. 2004;80(1):49-54.

168 Wadden TA, Foster DG, Sarwer BD, Anderson DA, Gladis M, Sanderson RS, Letchak RV, Berkowitz RL, Phelan S. Dieting and the development of eating disorders in obese women: results of a randomized controlled trial. Am. J. Clin Nutr. 2004;80(1):560-68.

169 Wermuth BM, Davis KL, Hollister LE, Stunkard AJ. Phenytoin treatment of the binge eating syndrome. Am J Psychiatr. 1977;134(11):1249-53.

170 Willi J, Grossaman S. Epidemiology of anorexia nervosa in a defined region of Switzerland. Am J Psichiatr. 1983;140(5):564-67.

171 Ximenes RCC. O impacto de transtornos alimentares sobre a saúde bucal de adolescentes aos 14 anos [monografia]. Recife (PE): Universidade Federal de Pernambuco;2002.

172 Zárate OG, Rodríguez GER. Anorexia y bulimia nerviosa. Aspectos odontológicos. Rev ADM. 2000;57(1):23-32.

173 Zero DT. Etiology of dental erosion: extrinsic factors. Eur J Oral Sci. 1996;104(2):162-77.

174 Zero DT, Lussi A. Erosion-chemical and biological factors of importance to the dental practitioner. Int Dent J. 2005;55(4 Suppl 1):285-90. 





ANEXOS 

ANEXO A - Comitê de Ética em Pesquisa

WE RITAL DAE CLINICAS DA FACULDADE DE MEDICINA DE RIBEIRÁO PRETO DA UNIVERSIDADE DE SÄO PAULO

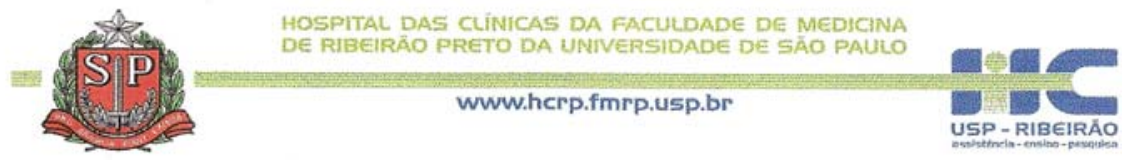

Ribeirão Preto, 25 de junho de 2007.

Oficio $n^{\circ} .2132 / 2007$

CEP/SPC

Prezado Professor,

O trabalho intitulado "LEVANTAMENTO DAS CONDIÇÕES DE SAÚdE BUCAL DE PACIENTES COM TRANSTORNOS ALIMENTARES E SUA CORRELAÇÃO COM A EROSÃO DENTÁRIA", foi analisado pelo Comitê de Ética em Pesquisa e APROVADO “AD REFERENDUM" em 25/06/2007, bem como o Termo de Consentimento Livre e Esclarecido, de acordo com o Processo HCRP nº. 2832/2007.

Lembramos que devem ser encaminhados a este CEP relatórios parciais e relatório final da pesquisa.

Atenciosamente.

PROF. DR, SERRGIO PEREIRA DA CUNHA

Coordenador do Comitê de Ética em Pesquisa do HCRP e da FMRP-USP

Ilustríssimo Senhor

PROF. DR. JOSE ROBERTO DE MAGALHÃES BASTOS

JULIANA JULIANELLI DE ARAÚJO

Faculdade de Odontologia de Bauru

Comitê de Ética em Pesquisa HC e FMRP-USP - Campus Universitário

FWA - 0000 2733; IRB - 00002186

Fone (16) 3602-2228 - E-mail : cep@hcrp.fmrp.usp.br 


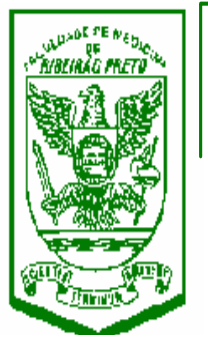

\section{FACUDADEDENEDICNADERIBERÃOPRETOUSP DEPARTAMENTODECÍNCAMÉICALABNUIRIÇÃO \\ Prof. Dr. JoséEmesto dos Santos \\ Av. Bandeirantes, 3900 - Ribeirão Preto-SP- CP14049-900 \\ FoneFax (016) 602-2366 \\ email: jedsanto@fimp.usp.br}

Carta de Informações ao Sujeito de Pesquisa

Esta pesquisa tem por finalidade verificar as condições de saúde bucal em relação à ocorrência de desgaste dentário nos pacientes com transtornos alimentares, especialmente a erosão. Estudos mostraram que este tipo de lesão ocorre especialmente em indivíduos que sofrem de bulimia ou anorexia ou indivíduos que fazem ingestão freqüente de alimentos ácidos, promovendo a destruição na superfície do esmalte, tornando os dentes sensíveis. O paciente que concordar em participar deste estudo responderá um questionário e será examinado pela cirurgiã dentista responsável pela pesquisa, a fim de verificar as condições de saúde bucal dos mesmos. O exame será realizado no próprio Departamento de Clínica Médica da Faculdade de Medicina de Ribeirão Preto, não oferecendo nenhum risco para o paciente. Caso haja necessidade de algum tratamento futuro o paciente será atendido no ambulatório do GRATA no Hospital das Clínicas da Faculdade de medicina de Ribeirão Preto, por esta pesquisadora. O material ficará retido pela autora, podendo ser publicado os resultados em jornais ou revista nacionais ou internacionais, assegurando a privacidade dos participantes.

Caso queira apresentar reclamações em relação a sua participação na pesquisa, poderá entrar em contato com o Comitê de Ética em Pesquisa, do Hospital das Clínicas e Faculdade de Medicina de Ribeirão Preto (HC - FMRP-USP) ou pelo telefone (16) 3602-2228 ou ainda pelo telefone da pesquisadora responsável (14) 3223-1084.

$$
\text { Assinatura do Sujeito da Pesquisa }
$$

Prof. Dr. José Roberto de Magalhães Bastos Orientador
Juliana Julianelli de Araújo

(Pesquisadora)

\begin{tabular}{c}
\hline Juliana Julianelli de Araújo \\
(Pesquisadora)
\end{tabular}

Prof. Dr. José Ernesto dos Santos Prof. Associado do Departamento de Clínica Médica da Faculdade de Medicina de Ribeirão Preto - USP 


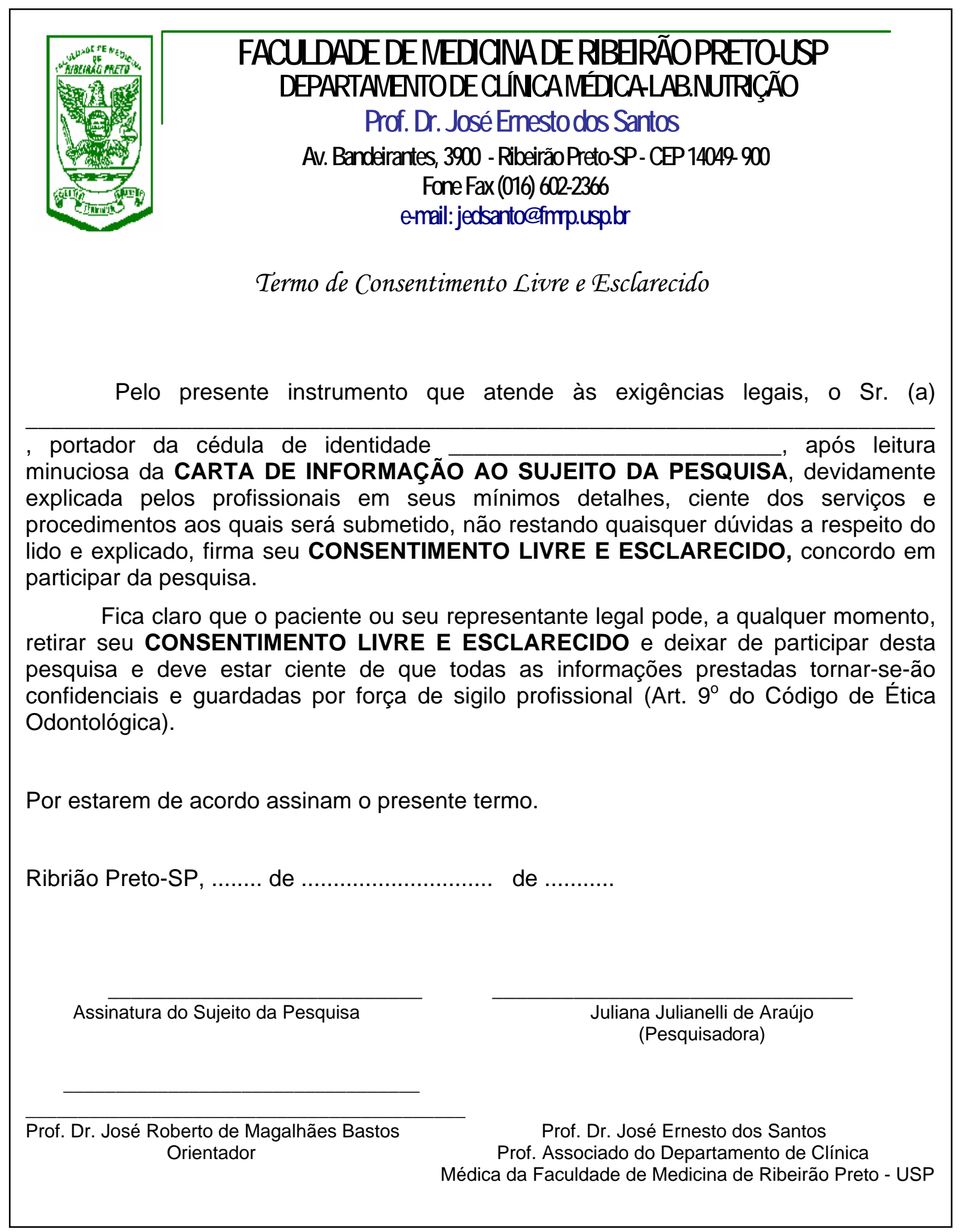





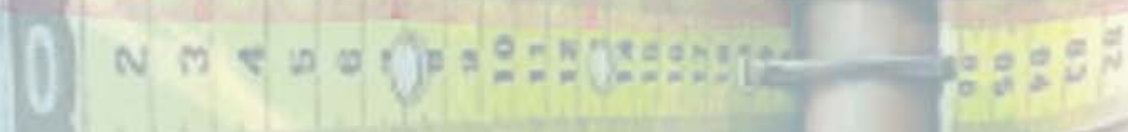

APÊNDICES 

APÊNDICE A - Questionário sobre o risco de abfração, abrasão, atrição e erosão dentária - Parte I.

\section{Universidade de São Paulo Faculdade de Odontologia de Bauru}

Al. Dr. Octávio Pinheiro Brisolla, 9-75 - Bauru-SP - CEP 17012-901 - C.P. 73 PABX (014) 3235-8000 - FAX (014) 3223-4679

Questionário sobre o risco de Abfração, Abrasão, Atrição e Erosão dentária.

Parte I

1. Identificação:

Nome:

Endereço:

Cidade:

Bairro: Telefone.

Data de Nascimento: Idade: Sexo: ( )M ( )F Cor:. Raça

Grau de escolaridade Ocupação:

Renda familiar per capta

Profissão:

Diagnóstico:

Tempo de Tratamento:

Data: Retorno: 
APÊNDICE B - Questionário sobre o risco de abfração, abrasão, atrição e erosão dentária - Parte II.

\section{Universidade de São Paulo Faculdade de Odontologia de Bauru}

Al. Dr. Octávio Pinheiro Brisolla, 9-75 - Bauru-SP - CEP 17012-901 - C.P. 73

PABX (014) 3235-8000 - FAX (014) 3223-4679

Questionário sobre o risco de Abfração, Abrasão, Atrição e Erosão dentária.

\section{Parte II}

\section{Questionário Erosão}

1. Com que freqüência você toma refrigerantes?
( ) uma vez por mês
( ) duas ou três vezes por mês
( ) uma vez por semana
( ) duas ou três vezes por semana
( ) mais de três vezes por semana
( ) todos os dias
( ) duas vezes por dia
( ) três vezes ou mais por dia
( ) não toma

1. Qual o refrigerante (marca) que mais consome?

2. Você tem o hábito de tomar sucos? ( )Sim ( )Não

3. De qual forma?
( ) natural
( ) concentrado
( ) em pó

4. Quais os sabores que você mais consome?
( ) Limão
( ) Maracujá
( ) Morango
( ) Caju
( ) Acerola
( ) Laranja
( ) Goiaba
( ) Manga
( ) Outros:
( ) Uva
( ) Abacaxi

5. Com qual freqüência você consome sucos?
( ) uma vez por mês
( ) uma vez por semana
( ) duas ou três vezes por mês
( ) duas ou três vezes por semana
( ) mais de três vezes por semana
( ) todos os dias
( ) três vezes ou mais por dia
( ) duas vezes por dia 
7. Você consome bebidas como Gatorade/ Marathon? ( ) Sim （ ) Não

Com qual frequência?

( ) uma vez por mês

( ) uma vez por semana

( ) mais de três vezes por semana

( ) duas vezes por dia

( ) duas ou três vezes por mês

( ) duas ou três vezes por semana

( ) todos os dias

( ) três vezes ou mais por dia

8. Com qual freqüência você toma logurtes?

( ) uma vez por mês

( ) uma vez por semana

( ) mais de três vezes por semana

( ) duas ou três vezes por mês

( ) duas vezes por dia

( ) duas ou três vezes por semana

( ) todos os dias

( ) três vezes ou mais por dia

9. Você toma bebidas alcoólicas? ( ) Sim ( ) Não

10. Qual bebida alcoólica você mais consome?
( ) cachaça/pinga
( ) uísque
( ) vodka
( ) vinho
( ) rum
( ) cerveja
( ) choops
( ) outras:

11. Com qual freqüência você toma essas bebidas alcoólicas?

( ) uma vez por mês

( ) uma vez por semana

( ) duas ou três vezes por mês

( ) mais de três vezes por semana

( ) duas ou três vezes por semana

( ) duas vezes por dia

( ) todos os dias

( ) três vezes ou mais por dia

12. Você possui algum problema estomacal?

( ) Sim ( )Não

13. Se possuir, qual é este problema?

( ) dores estomacais/gastrite ( ) úlcera

( ) refluxo

( ) vômitos freqüentes

14. Realiza alguma prática de emagrecimento? ( ) sim ( ) não Qual? ( ) medicamentos ( ) jejum prolongado ( ) outras.

15. Quantas vezes por dia você escova os dentes?
( ) uma vez
( ) três vezes
( ) duas vezes
( ) cinco vezes ou mais
( ) quatro vezes
( ) todas as vezes que come 


\section{ABRASÃO}

16. Quantas vezes por semana você costuma dormir sem escovar os dentes?
( ) uma vez
( ) duas vezes
( ) cinco ou seis vezes
( ) todos os dias
( ) três a quatro vezes

17. Com qual freqüência você visita o cirurgião-dentista?
( ) todo mês
( ) a cada 2 ou 3 meses
( ) a cada 6 meses
( ) uma vez por ano
( ) a cada 2 anos
( ) mais que 2 anos
( ) não vou ao dentista

18. Qual o tipo de cerdas que sua escova possui?
( ) macia
( ) média
( ) dura

19. Qual movimento você utiliza para escovar a superfície vestibular (da frente) dos dentes?

( ) de trás pra frente/ frente pra trás

( ) de cima pra baixo / baixo pra cima

( ) movimento circular

20. Você usa algum outro produto para escovar os dentes (além do creme dental)?

( ) Não ( ) Sim. O que?

\section{ABFRAÇÃOI ATRIÇÃO}

21. Ao acordar, você sente dores na região dos maxilares?
( ) Sim
( ) Não

22. Alguém já observou que você range os dentes ao dormir (bruxismo)?
( ) Sim
( ) Não

23. Quando está nervoso(a), você tem o hábito de apertar os dentes com força (morder)?
( ) Sim
( ) Não

24. Você tem o hábito de morder objetos?
( ) Não
( ) Sim: O que?

25. Você tem alguma dificuldade para mastigar? Possui problemas de oclusão?
( ) $\operatorname{Sim}$
( ) Não

26. Possui algum hábito bucal?

( )apertar os dentes ( ) morder as bochechas ( ) ranger os dentes

( ) morder objetos ( ) morder a língua ( ) roer unhas

( ) morder lábios ( ) mascar chicletes ( ) outros

Qual a freqüência? ( ) sempre ( ) ás vezes ( ) raramente

27. Toma algum tipo de medicamento?
( ) $\mathrm{Sim}$
( ) Não
Qual. 
APÊNDICE C - Ficha - Índice de desgaste dentário

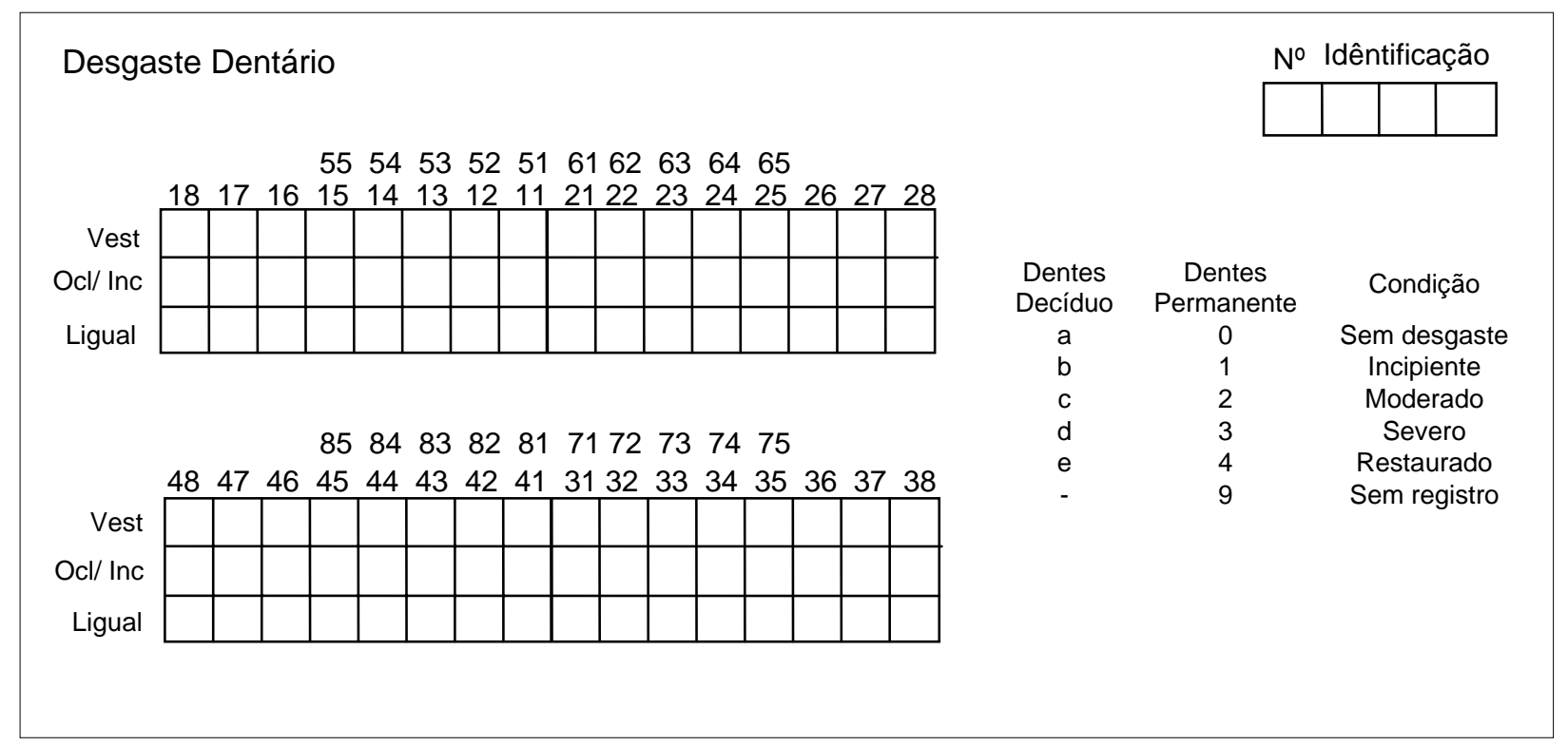

